Historic, Archive Document

Do not assume content reflects current scientific knowledge, policies, or practices. 
- 
$\therefore \quad k E S$

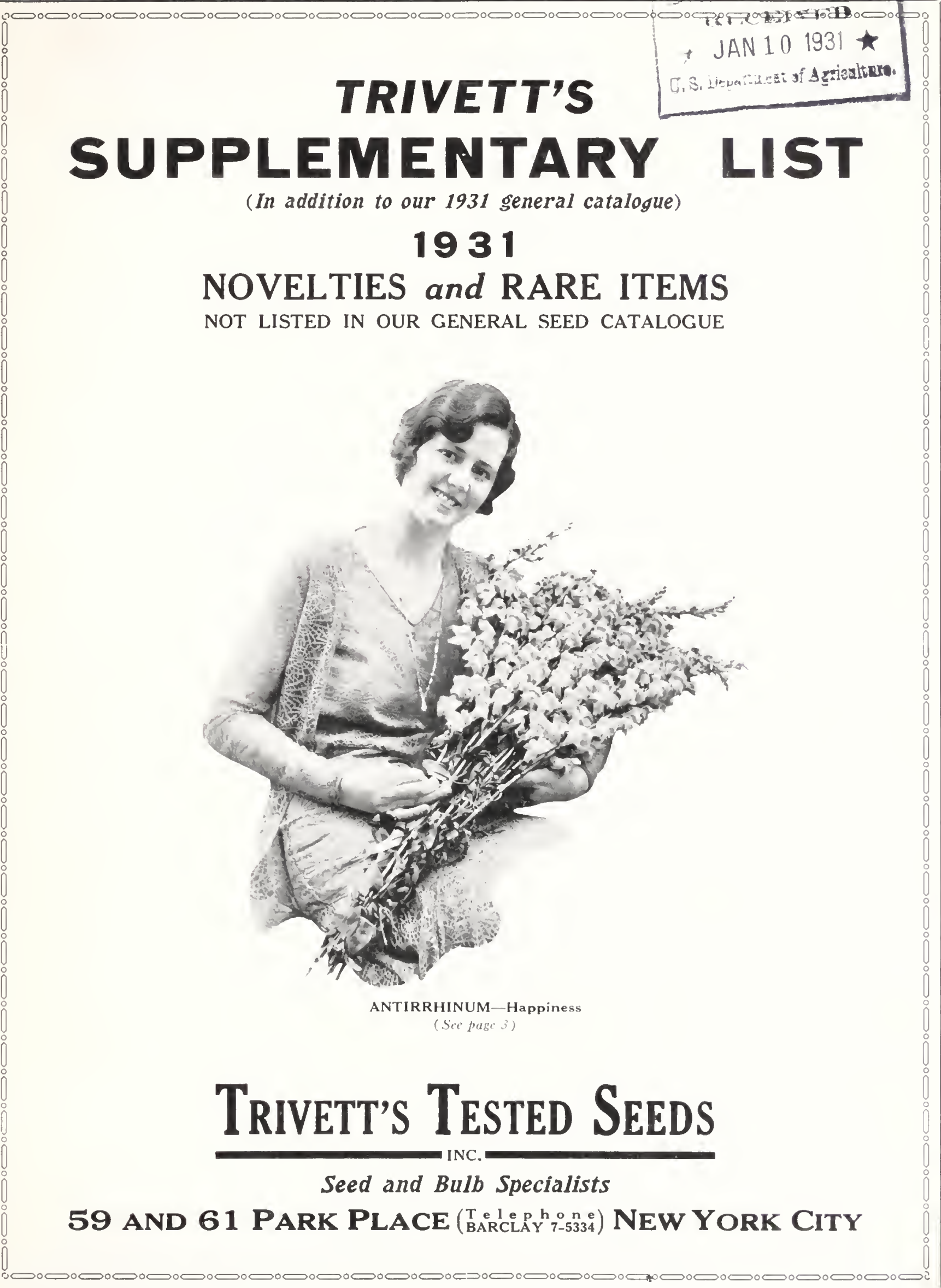




\section{How TRivetT's Tested SeEds ARe Stored}

All our flower and vegetable seeds are stored and preserved in steel drawers, especially constructed for this purpose; the bodies are formed from one piece of gal-

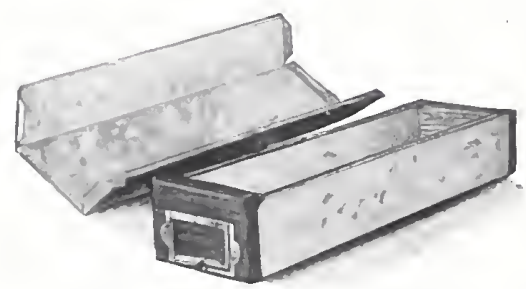

Steel seed drawer, showing the body cut from one piece of steel vanized sheet steel and are housed in steel-lined cabinets.

The danger of mixing is reduced to a minimum, the seed is protected from dust, insects, mice, etc. Every up-to-date method is employed by us to assure the proper storing and preserving of seed during the selling season.

\section{TRIVETT'S TESTED SEEDS}

are tested for germinating powers, in electrically heated testing machines, at an even temperature and under moisture conditions similar to those of the average greenhouse or hotbed.

Trivett's Tested Seeds are also tested for purity, they will be found exceptionally clean and free from grit and foreign material.

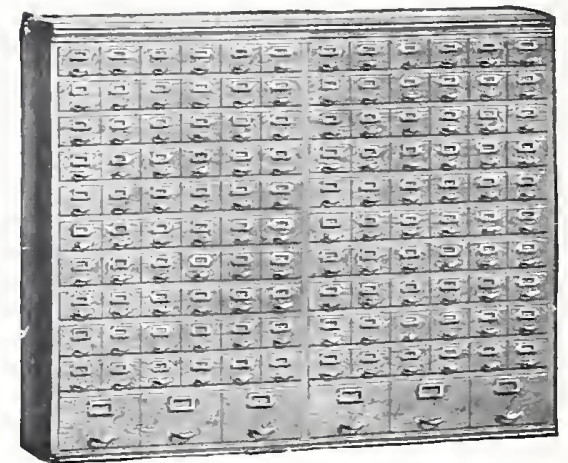

One of the steel lined cabinets in which the special seed drawers are housed

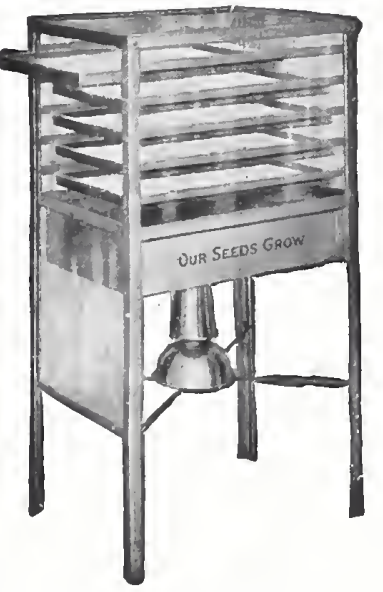

One of our electrically heated seed testing

\section{TESTED and GUARANTEED}

Contrary to the general disclaimer of the seed trade, Trivett's Seeds and Bulbs are guaranteed. For particulars, see General Catalogue.

Trivett's "Best by Test" Flower and Vegetable seeds are put up by us in packets of generous over-size quantities, stamped with the date, and sealed with our trade-mark.

For people who demand the best

\section{TRIVETT'S TESTED SEEDS Seed and Bulb Specialists}

59 and 61 PARK PLACE (Tel. Barclay 7-5334) NEW YORK CITY 
This Supplenentary Catalogue is issued by us in addition to our General Catalogue, and contains the best of the recent Novelties, also many choice, rare items which have not yet found their place in our General Catalogue. A copy of our General Catalogue will be supplied upon request.

Old varieties of many flowers and vegetables reproduced year after year through a period of time 'run out,' become exhausted and more susceptible to diseases and insect attacks than the more rigorous new and improved strains. We are constantly on the watch for new and improved strains to offer to our customers.

Originator's Seeds are supplied by us in every instance, wherever possible. We firmly believe the original source is the best; no one can possibly know better than the originator the real merits of his creation, and how best to preserve and reproduce them.

$I_{N}$ ADDition to supplying only the highest grades of Seeds and Bulbs, we have now perfected a method of treating many seeds and bulbs with a special preparation of our own, as a preventive against seed and bulb carried diseases. All such items bear our red seal.

TREATED $\mathcal{O}$ SEEDS - TREATED $\mathcal{O}$ BULBS

Alt items marked $\boldsymbol{B}$ in this catalogue are especially suitable for rock and alpine gardens.

Trivett's Tested Seeds are put up by us in generous oversize packets, stamped with the date, and sealed with our trade mark.

Trivett's Tested Seeds, Inc. 


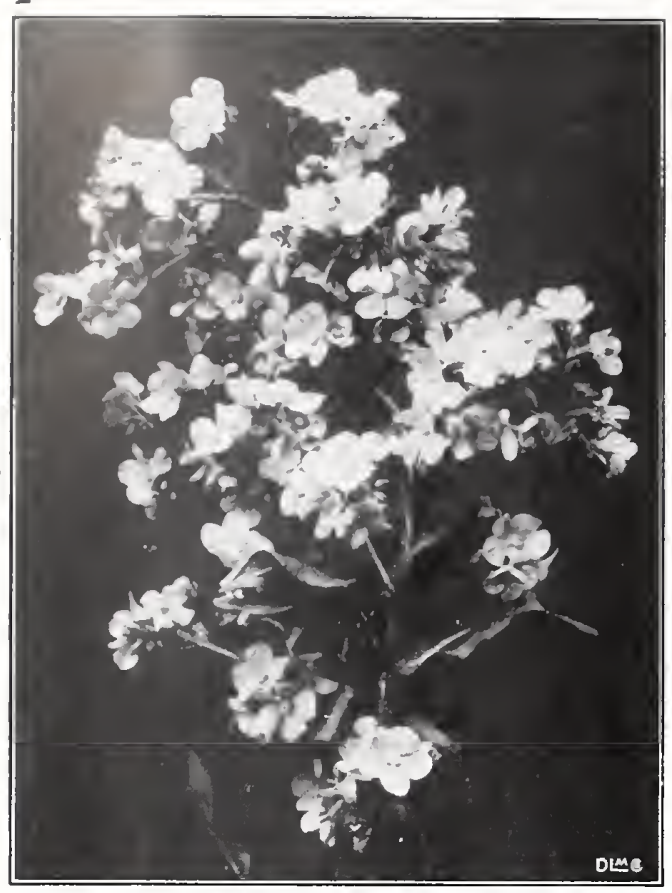

ANCHUSA - Lissadell

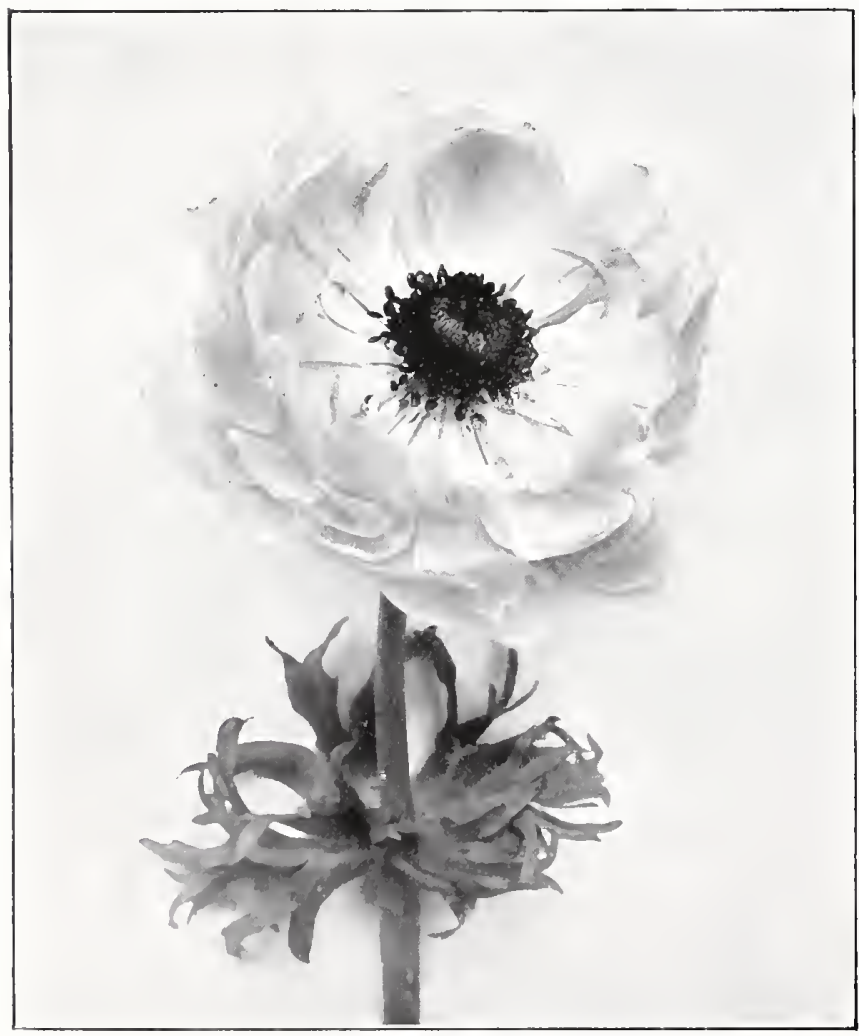

T.T.S.

ANEMONE-Creagh Castle Improved

\section{ACACIA}

Greenhouse flowering shrubs, ornamental and cutting.

Baileyana. (Cootomundra Wattle.) Very free flowering golden yellow. Height about 3 feet. Oz. $\$ 2.00 \quad 1 / 4$ oz. 60c. Pkt. 25c.

Lophantha. Handsome greenhouse shrub, allied to the Mimosa. Flowers yellow, foliage finely cut. Height 6 feet.

\section{ACHILLEA-Cerise Queen}

$$
\text { Oz. } \$ 1.00 \quad 1 / 4 \text { oz. 30c. Pkt. } 10 \mathrm{c} \text {. }
$$

Perennial. For hardy borders and cutting. Height 2 feet.

Beautiful new variety, dark cherry red.

Pkt. 75c.

\section{ACONITUM-Spark's Variety}

Perennial. For hardy borders and cutting. Height 5 feet.

Fine, tall growing sort with very dark blue flowers.

Pkt. 50c.

\section{ADONIS ALEPPICA}

Anmul. For display and cutting. Height 20 inches.

The plant is pyramidal in habit, producing shining, deep blood red flowers of greatest brilliance, measuring 3 inches across, and with vivid green feathered foliage.

\section{AGERATUM}

Annual. For edging, bedding and general display.

Fraseri. Deep amethyst blue, compact habit, early flowering.

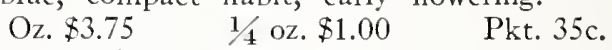

Lasseauxi. Exceptional for cut flowers. Mauve pink. Oz. $\$ 3.75 \quad 1 / 4$ oz. $\$ 1.00 \quad$ Pkt. $35 \mathrm{c}$.

Rose Pearl. Dwarf for edging, lilac rose, deeper center.

\section{ALYSSUM} (Pkts. only) Pkt. 50c.

Anmual. For edging, bedding and general display.

Lilac Queen. Delicate lavender growing about 8 E in. high. Oz. $\$ 1.50 \quad 1 / 4$ oz. 50c. Pkt. $15 \mathrm{c}$.

Primrose Queen. Cream or straw color. Height B 8 in. Oz. $\$ 1.50 \quad 1 / 4$ oz. $50 \mathrm{c}$ Pkt. $15 \mathrm{c}$.

\section{ANAGALLIS (Pimpernel)}

Annual. For edging, bedding, etc. in sunny places. 6 inches. Trivett's Large Blue. An improvement over the original. The plants spread rapidly and bloom freely. The flowers are of real turquoise blue color. Must have a sunny place. Oz. $\$ 3.00 \quad 1 / 4$ oz. $\$ 1.00 \quad$ Pkt. 35c.

\section{ANCHUSA TREATED $\bigcirc$ SEEDS}

Trivett's Annual Blue. Introduced by us last year. The plants are of fine, compact habit, producing sprays of vivid blue flowers for cutting. Height $1 \frac{1}{2}$ feet. Pkt. $50 \mathrm{c}$. Lissadell. Hardy perennial. Improved Gentian blue. Pkt. 50c.

Picotee. Hardy perennial. Distinct blue with white.

\section{ANGELONIA GRANDIFLORA}

Greenhouse perennial. Elegant conservatory plant. Height 21/2 feet.

Pretty greenhouse plant with numerous pale mauve flowers and tigered throats produced in dainty sprays, interspersed with rich, dark green foliage. Blooms first season from seed.

Pkt. 50c

\section{ANEMONE Perennial. For greenhouse cut flowers or outdoors.}

Creagh Castle Improved. Greatly enlarged blooms on long strong stems in a wide range of rich colors. Exceptionally suitable for greenhouse culture as a choice cut flower.
Pkt. 50c.
Alpina. The strong growing, beautiful mountain species known to every climber of the Swiss Alps. The flowers are mostly white tinted with blue, but vary somewhat from seed. Height about 15 inches. $\quad$ Oz. $\$ 3.00 \quad 1 / 4$ oz. $\$ 1.00 \quad$ Pkt. 35c.

THIS SIGN DENOTES THOSE ITEMS WHICH ARE SUITABLE FOR ROCKERIES AND ALPINE GARDENS 


\section{ANTIRRHINUM treated 0 Seeds \\ For Greenhouse Forcing} If you grow Antirrhinums, be sure you buy good seeds. In the long run, the price of the seeds rhinum Seeds are procured direct from the originators, especially grown for forcing purposes.

Choice greenhouse forcing sorts.

Afterglow. Beautiful golden bronze; Winter flowering; Silver Medal at Lotisville and First Prize at Buffalo. Pkt. $\$ 3.00$

Ceylon Court. Strong, close-set spikes of soft canary yellow; very productive.

Pkt. $\$ 1.50$

Indian Summer. Rich glossy copper color; a most attractive shade.

Pkt. $\$ 1.50$

Roman Gold. The color of this variety is a charming combination of pink, copper and gold tints all blended together in one beautiful color. Pkt. \$2.50

Sutton's Cloth of Gold. (Sutton's Seed.) Tall growing sort, producing long spikes of soft golden yellow; a very desirable sort.

Pkt. 75c.

Goliath. (Raiser's description.) We are now able to offer seed of this splendid variety. It throws up long and massive spikes bearing immense individual flower of beautiful coloring, salmon rose above with orange center shading downwards to pale apricot. Much superior to the so-called Maximum type.

Pkt. $\$ 1.00$

Happiness. A grand new pink sort, a pleasing shade of real pink. Better in every way than Philadelphia Pink, its male parent. Has immense flowers closely set. Keeps a long time when cut and has many other merits. Highly recommended.

Pkt. $\$ 3.00$

Harmony. Rich terra cotta pink with yellow center. This is a color combination that is most charming and much desired.

Pkt. $\$ 1.00$

Rose Queen. New Winter blooming sort, beautiful. dark pink, large flowering. A true Winter bloomer. For December-January flowering sow seed July 1st to 10 th and bench by October 1 st. Can be planted close, 6 in. by 8 in. Awarded Silver Medal, National Flower Show at Minneapolis, also First Prize at Cleveland Show.

Pkt. $\$ 3.00$

\section{ANTIRRHINUM, ROCK HYBRIDS MIXED}

This pretty hybrid forms small bushes with variously colored flowers in shades of rose, pink, purple, mauve, etc., and is eminently suitable for rock and alpine gardens, edging, etc. 5 pkts. $\$ 3.50$, pkt. $75 \mathrm{c}$.

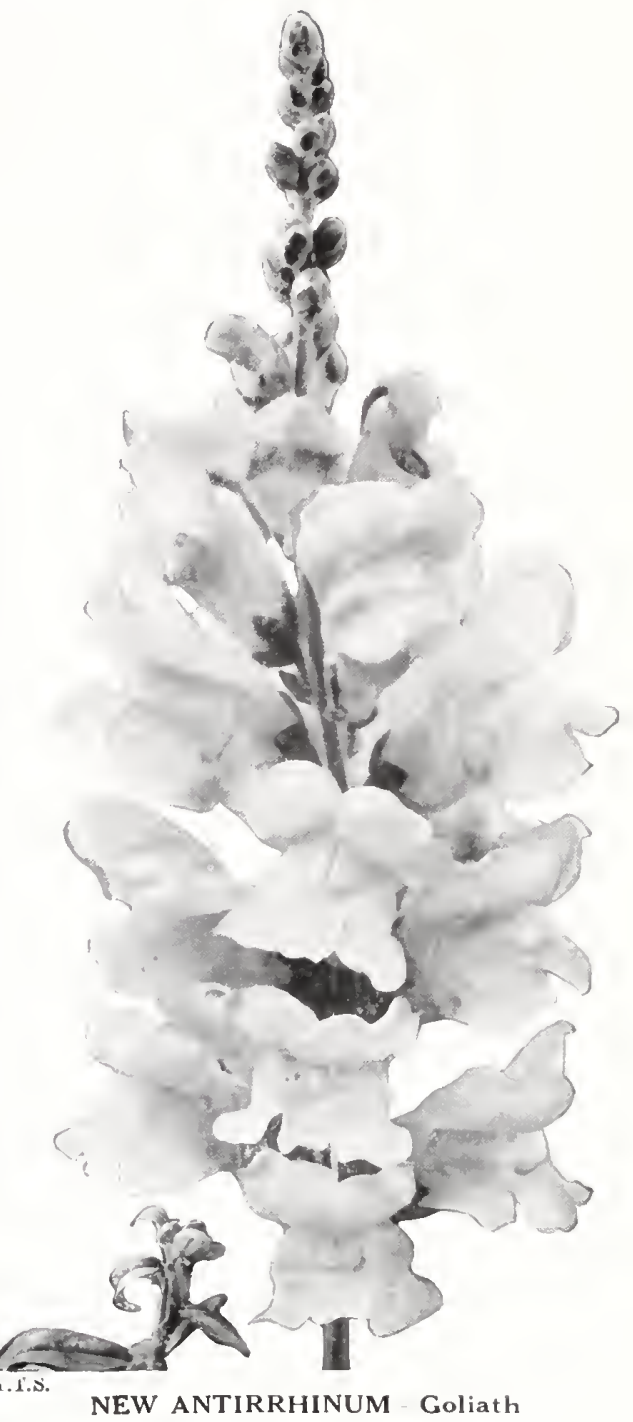

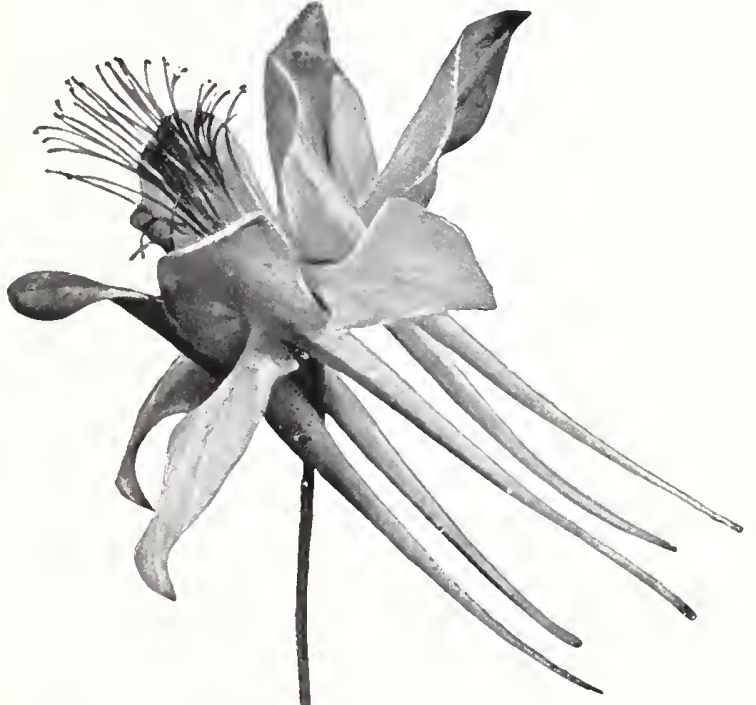

NEW AQUILEGIADobbie's Imperial Hybrids

\section{AQUILEGIA TREATEd $\circlearrowleft$ SEEDS}

Perennial.

For borders and cutting.

Height 21/2 feet.

Copper Queen. Rich copper red, long spurs of darker shade and straw-colored throat.

Pkt. 50c.

Trivett's Lavender. Rich, deep lavender with pure white corolla, a magnificent long spurred and large flowered sort. Pkt. $\$ 1.00$

Trivett's Violet. Introduced by us in 1930, the plant is tall in habit, reaching a height of about 4 feet and producing large, longspurred blossoms of rich deep violet with pale yellow corolla.

Pkt. $\$ 1.00$

Dobbie's Imperial Hybrids. (Dobbie's Seed.) Considered by many to be the finest mixture of giant long spurred sorts. The range of colors and shades is extraordinary.

Pkt. $75 \mathrm{c}$.

Mrs. M. Nicholls. A much improved strain of Aquilegia caerulea. Bolder flowers, rich blue with white.

Pkt. 50c.

Crimson and Gold. (Sutton's Seed.) Very attractive variety with bright crimson and gold, long spurred flowers, in great profusion. Height 3 feet.

Pkt. 50c.

SEEDS OF ALL ITEMS MARKED $\mathcal{O}$ ARE TREATED AS A PREVENTIVE AGAINST SEED-CARRIED DISEASES 


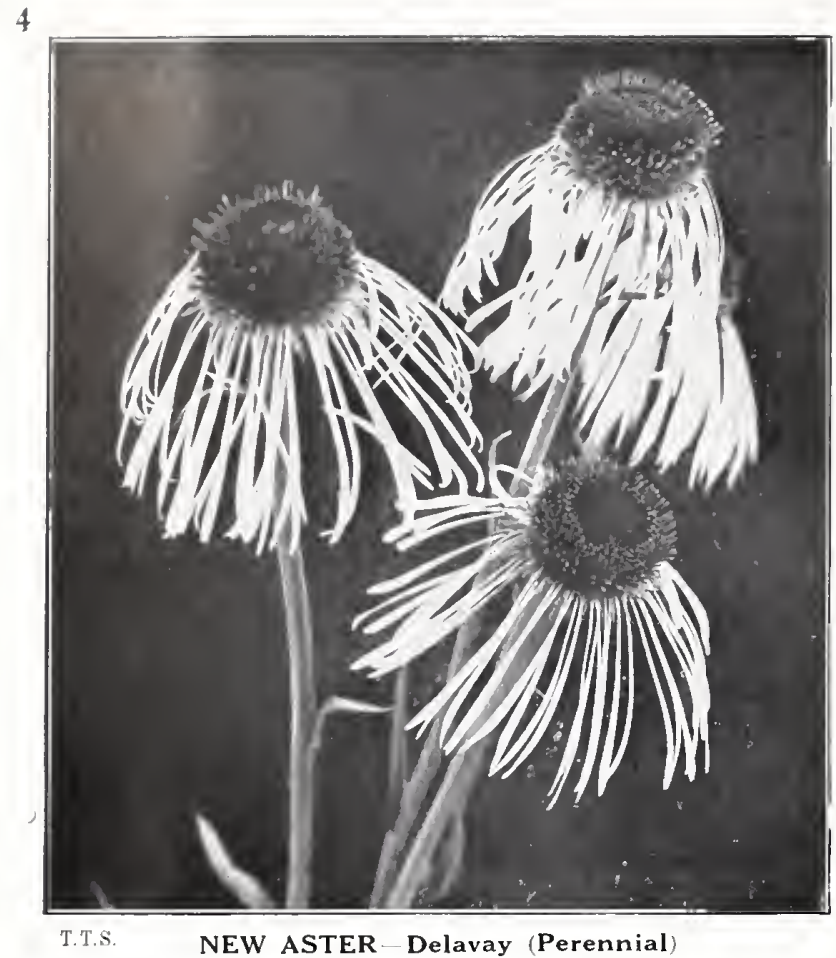

\section{ASTER TREATED $\rightarrow$ SEEDS}

Annual. For cutting and display.

For full list of Asters, please refer to our general catalogue.

Aurora. Quite different from any other Aster, the center of the flower is bright yellow with an outer circle of delicate blue. forming a striking contrast. The plants are of robust growth and about 2 feet in height.

Pkt. 50c.

Everlasting Rose. This curious variety appeared lately in the fields of an Aster specialist. It resembles a large Helichrysum. When cut and dried it retains its color and shape just like an Everlasting Flower. Pkt. 50c.

Giant Peony Swansdown. A new variety of the CALIfornia Giant (Peony Flowered). Pure white of gigantic size, 4 to 5 inches across, unquestionably the finest white Aster of this type.

Pkt. 50c.

Giant Peony Maiden's Blush. A pure even shade of shell pink.

Pkt. 50c.

Giant Peony Azure-Blue. Immense size, magnificent shade of clear blue.

Pkt. 50c.

Peerless Yellow. (Raiser's description.) It has been difficult to get a good yellow Aster. We have been working constantly for several years and have at last developed one that is quite good, height about 2 feet, flowers of good size and form. The color is a deep yellow when first opened and fades slightly as it ages.

Pkt. 50c

\section{NEW ASTER, DELAVAY (Perennial)}

Unique hardy perennial Aster, nothing more lovely can be imagined than this beautiful Chinese species. Delightful shade of lavender-blue with jet black center. see illustration above.

Pkt. 50c.

\section{ARABIS (Rockcress)}

Perennial. For rockeries, edging, walls, etc. Height 6 inches. Alpina grandiflora superba. Great improvement over $\mathbf{F}$ the type, large pure white flowers.

$$
\text { Oz. } \$ 4.50 \quad 1 / 4 \text { oz. } \$ 1.25 \quad \text { Pkt. 50c. }
$$

Rosea. Dwarf habit, vivid rose pink. (Seed very scarce.) E]

Pkt. $\$ 1.00$

\section{ARCTOTIS BREVISCAPA AURANTIACA}

Although a half hardy perennial, this should be treated as an annual. The variety we offer is an improvement over Arctotis breviscapa, being a deeper and more attractive shade of orange yellow with purple disc. Splendid for bedding, mass effects and cutting. Height about 8 inches. Pkt. 50c.

\section{ARENARIA MONTANA (Sandwort)} Perennial. For rockeries, edging, etc. Height 6 inches.

A hardy perennial growing in close tufts, profusely covered with small, silvery white flowers which appear in Spring.

(Packets only) Pkt. 50c.

\section{ARNEBIA CORNUTA (Prophets Flower)}

Annual. For cutting and display. Height 2 feet.

Small spikes of golden yellow flowers with rich velvety brown blotch on each lobe of petals, extremely showy, easily grown.

Pkt. 50c.

\section{ARNICA MONTANA (Mountain Tobacco)}

Perennial. For rockeries and naturalizing. Height 15 inches. A beautiful Alpine plant resembling a miniature Sunflower, F 2 inches in diameter, fragrant yellow, a lovely Alpine L effect can be obtained by planting in combination with blue Campanulas in rockeries, etc.

$$
1 / 4 \text { oz. } \$ 1.50 \quad 1 / 8 \text { oz. } 85 \text { c. Pkt. } 35 \text { c. }
$$

\section{ARTEMISIA SACRORUM VIRIDIS (Summer-fir)}

Annual. For single specimens and pots. Height 4 feet.

A plant of graceful pyramidal habit with light and elegant foliage, valuable as single specimens on lawns, etc. and as pot $\begin{array}{llll}\text { plants. } & \text { Oz. } \$ 2.50 \quad 1 / 4 \text { oz. } 75 \text { c. } & \text { Pkt. 30c. }\end{array}$

\section{ASCLEPIAS CURASSAVICA}

Decorative greenhouse pot plant. Height 2 feet.

Very useful and showy plant for greenhouse and conservatory. Flowers reddish orange scarlet, produced in large, erect clusters. Although a perennial, seed sown early produces fine specimens the first season.
$\mathrm{Oz} . \$ 3.00$
$1 / 4$ oz. $\$ 1.00$
Pkt. 35c.

\section{ATRIPLEX HORTENSIS CUPREATA}

Annual. Foliage plant, decorative. Height 5 feet.

Extremely useful as an ornamental plant, red foliage with dark violet stalks. Oz. $\$ 1.50 \quad 1 / 4$ oz. 50c. Pkt. $15 \mathrm{c}$.

\section{AUBRETIA-TRIVETT'S ROSE}

Perennial. For rockeries, edging, walls, etc. Height 4 inches.

$\mathbf{R}$ This variety produces large, cushion-like clumps which are covered with rosy carmine flowers. Pkt. 50c. 
Sutton's Prize Single Mixed. Plain edged. Saved from the richest and most varied flowers; all shades are included, from the deepest crimson to the lightest pink as well as orange, yellow; white, etc.

Sutton's Double Mixed. Plain edged. Comprising all the separate named varieties and many shades not offered. 'This is a splendid mixture of plain edged sorts.

For other sorts, see our General Catalogue.

\section{BEGONIA_Fibrous-Rooted}

Everblooming bedding and edging sorts.

Sutton's Loveliness. One of the largest flowered bectding Begonias. The lovely clear rose pink blossons have made it a great favorite. Pkt. $75 \mathrm{c}$

Trivett's White Queen. New. Largest pure white flowers, light green foliage and stems. Highly recommended. 1'kt. 50c

Rosabelle. Splendid novelty, compact little plants only 6 inches high. Green foliage covered with flowers of pure rose pink. Ideal for bedding.

\section{REX BEGONIA}

\section{Ornamental foliage. Greenhouse pot plant.}

Trivett's Prize Hybrids. Fine specimens, may be grown from seed in five months. The handsome leaves show a great diversity in form and coloring.

\section{BROOM}

If sown in Spring or early Summer, strong plants will be produced which flower freely in the following year.

Crimson and Gold.

A remarkable Hlowering shrub which created quite a sensation when first offered. The plants are as hardy and flower with the same freedom as the common Broom. Each blossom has rich crimson wings and golden standard. Seedlings commence flowering the second season, so to $90 \%$ coming true from seed

Pkt. 50c.

White. Well known hardy shrub, producing in early summer a profusion of white flowers on long sprays. Excellent for cutting.

Spanish. Pkt. 20 . yellow variety is well worth growing for its lecorative effect in the shrubbery border, as well as for the long, slender sprays of flowers it affords for cutting. Fine specimen bushes can be grown from seed in two seasons. Height 6 to 10 feet. Pkt. 25c.

\section{CALCEOLARIA}

Trivett's Profusa Hybrids. The plants possess the same habit as $C$. profusa, but the flowers are larger, ranging fron vellow to reddish bronze, very lasting. A fine plant for indoor decoration. Height 2 to 3 feet.

Pkt. $\$ 1.00$

The Fairy. This hybrid comes from a wild (hilian species crossed with $C$ profusa. It is the deepest yellow Calceolaria we know, and the elegant sprays of small flowers are most decorative. Will be much appreciated as a pot plant for conservatory or house. IJeight about '2 feet.

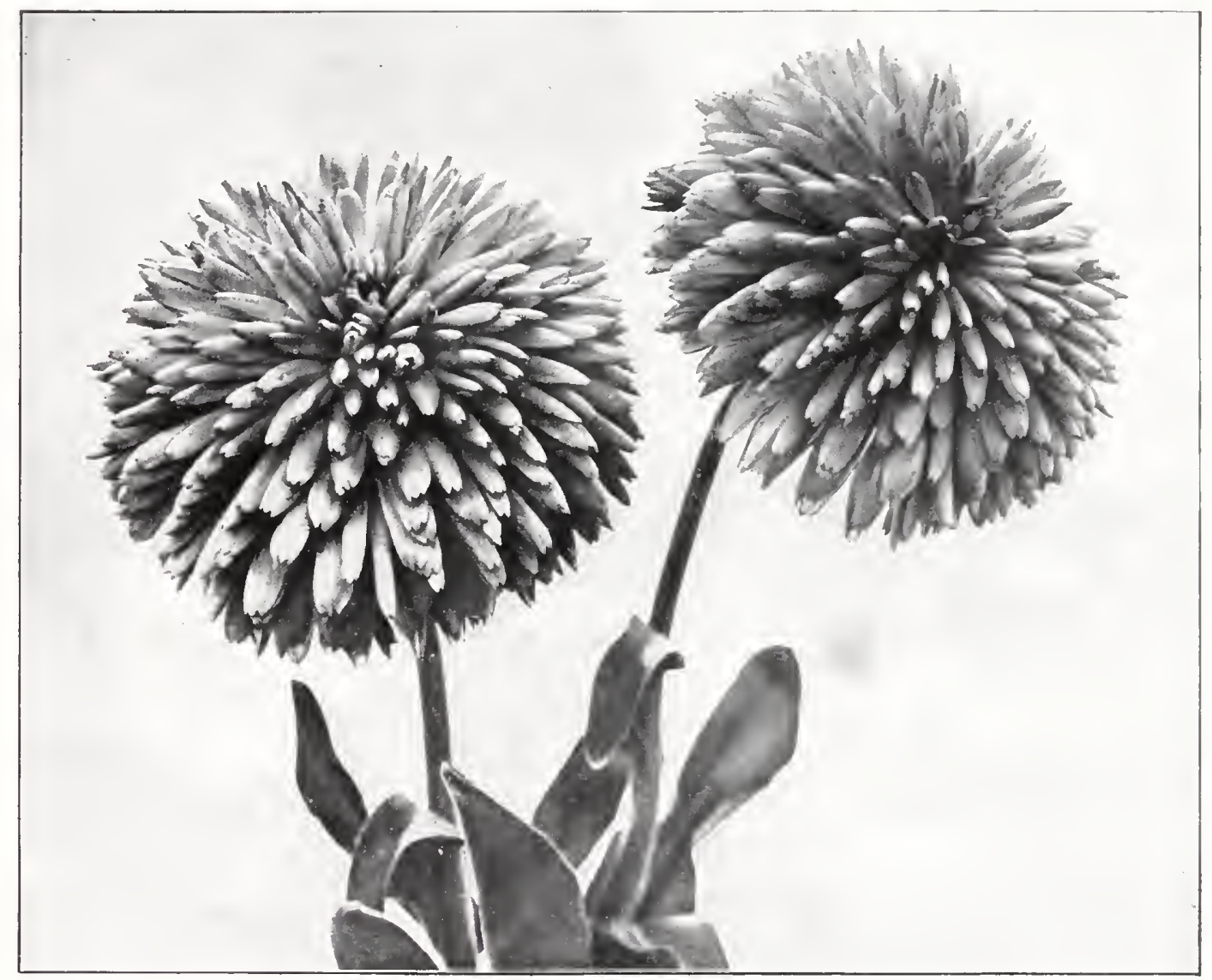

CALENDULA-RADIO

\section{CALENDULA-Scotch (or Pot) Marigold. One of the most useful of A munuls}

Radio. (1llustrated.) An English novelty of merit, being a new "break" in Calendulas. The petals are beautifully quilled and fluted which enhances the beauty of the globular flowers. The color is soft glowing orange.

$$
\text { Oz. } \$ 3.50 \quad 1 / 4 \text { oz. } \$ 1.00 \quad \text { Pkt. } 25 \mathrm{c} \text {. }
$$

Sensation. (Campfire.) The largest of all. Extremely double blossom on long, strong stems; rich orange washed over with a sheen of scarlet; truly an outstanding novelty.

Ball's Gold. Improied stock, originator's seed. Upright habit, long stemmed, deep golden yellow. 


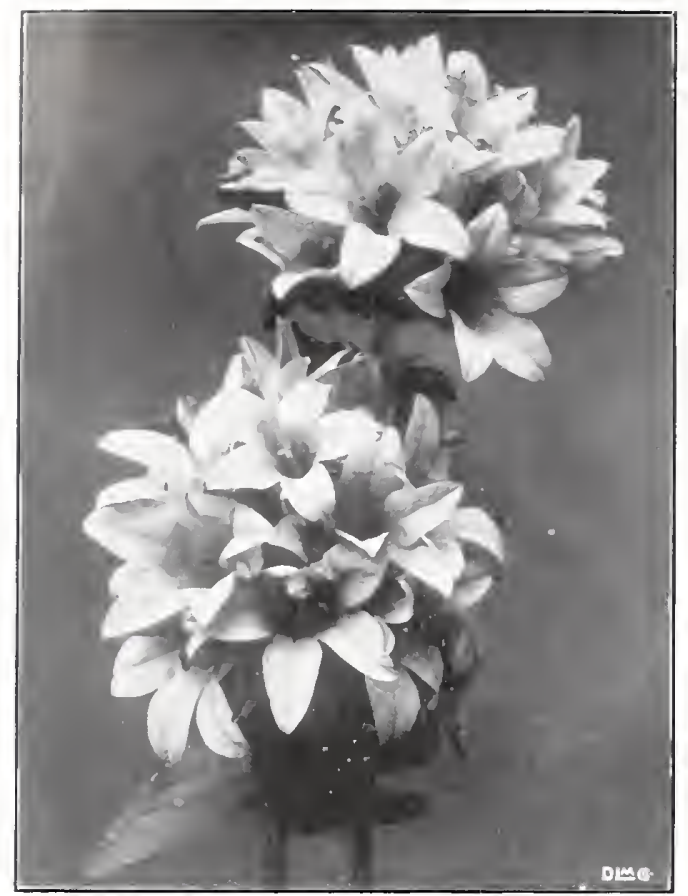

CAMPANULA-Glomerata Superba

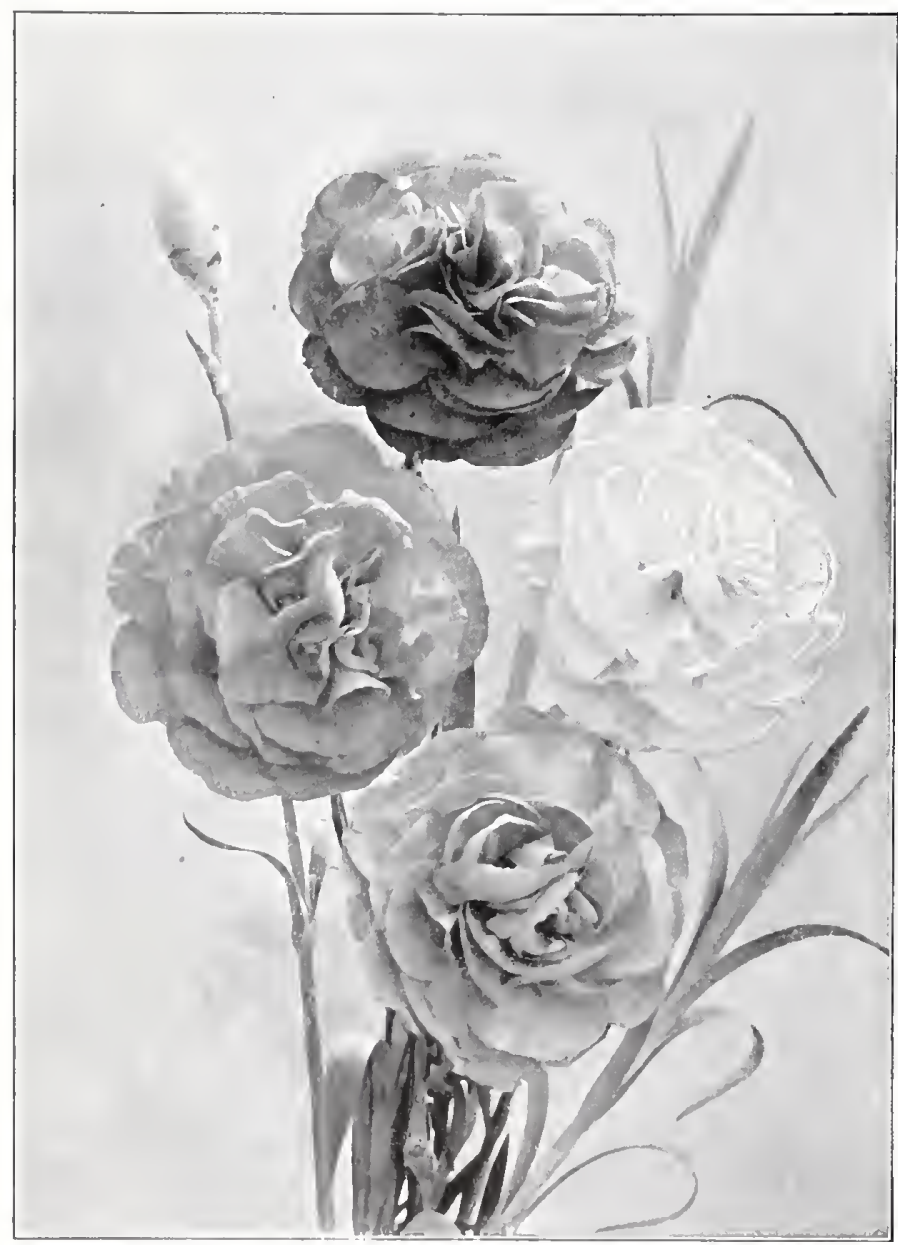

T.T.S.

BORDER CARNATIONS--Trivett's Prize Mixed

\section{CAMPANULA}

\section{(Basket Campanula)}

Fragilis. Long flowering branches, fine for suspended baskets and window boxes. Flowers are clear light blue. Very similar to C. isophylla. (Perennial.) Pkt. $\$ 1.00$.

Vidali. Magnificent greenhouse pot plant, producing large sweet scented white flowers. Height 2 feet.

Calycanthema Strawberry-Pink. Pkt. $\$ 1.25$. saucer.) A lovely new shade of color which we now add to the other colors listed in our general catalogue. Oz. $\$ 5.00 \quad 1 / 4 \mathrm{oz} . \$ 1.50 \quad$ Pkt. $50 \mathrm{c}$.

Barbata. Has been called the queen of the lower F Alpine meadows; large, greyish blue bells on $12 \mathrm{inch}$ T. stems; hardy perennial; makes a splendid companion to Amica montana in the rock garden. Height about 15 inches. Oz. $\$ 5.00 \quad 1 / 4$ oz. $\$ 1.50$ Pkt. 50c.

Canarina. Climbing perennial Campanula. A magnificent plant for suspended baskets with numerous large, bell-shaped flowers of orange color veined with red and deep red border. Also useful for the decoration of walls and for cutting. 5 pkts. $\$ 3.50 \quad$ Pkt. $75 \mathrm{c}$.

Garganica Major. Lovely trailing sort for the E. rock garden. Charming pale blue flowers.Pkt. 50c.

Glomerata Superba. Improvement over C. glomerata, producing large, deep rich blue flowers in loose heads. Hardy perennial. Height $1 \frac{1}{2}$ feet. For herbaceous borders.

Pkt. 50c.

For other varieties of Campanulas, please refer to our General Seed Catalogue

\section{CARNATIONS Biennial TRIVETT'S EARLY FRENCH}

Plants bloom in 5 or 6 months after sowing and continue to flower until the end of the Summer. The large flowers are very double and are borne on stiff, wiry stems 15 to 18 inches high. Our strain will produce about $90 \%$ double flowers and come true to color. They are ideal cut flowers. The seed can also be sown in the Fall and the plants carried over the Winter in frames

White, Rose, Scarlet, Pink, Yellow, Maroon, and Ruby. Each color.

$1 / 2$ oz. $\$ 5.00 \quad 1 / 4$ oz. $\$ 2.75 \quad 1 / 8$ oz. $\$ 1.50 \quad$ Pkt. 50c. Collection-One packet each of the above 7 colors separate, $\$ 3.00$

\section{PERENNIAL BORDER CARNATIONS}

Trivett's Prize Mixed. A special mixture blended by us from the most choice strains of hardy border Carnations. The plants attain a height of 2 feet, bearing abundance of large, fully double flowers on splendid stems and in a wide range of choice colors.

American Tree- 100 seeds $\$ 1.50$ Saved from the newest and finest varieties, can be used with striking effect in beds and borders. Seed sown in February or March and planted out will flower in August and September, and in the following year great sheaves of bloom are produced. Our seed is saved from selected flowers only.

Special, 50 seeds $\$ 1.25$ For other varieties of Carnations, please refer to our General Seed Catalogue 


\section{CElosia plumosa}

We offer a special strain of the Plumed Cockscomb. The splendid habit of this strain makes it ideal for pots in greenhouse or general display in thegarden. (Illustrated.)

Trivett's Yellow King. Clear bright yellow.

Trivett's Crimson King. Rich deep red.

Each of the two colors, Pkt. 50c.

Chrysanthiflora. (Celosin brysoni.) One of the most effective cut flowers; a wider range and more beautiful colors are found in this Celosia than in any other Autumn flower. Lasts a long time when cut Mixture. Oz. $\$ 6.00 \quad 1 /$ oz. $\$ 1.75 \quad$ Pkt. $50 \mathrm{c}$

Childsi. (Chinese Hoolflower.) Round, ball-shaped flowers on strong stems for cutting. Crimson, Pink and Yellow. Each, 0z. $\$ 3.001 / 40 z . \$ 1.00 \quad$ Pkt. 25c. For mixture, see our General Catalogue.

\section{CENTAUREA}

\section{Perennial. For borders and cutting.}

Montana Blue. Superb large flowers. 2 feet Montana White. Companion to above. 2 feet. Each of above, Oz. \$3.00 1/4 oz. \$1.00 Pkt. 25c Montana Rose. New! Clear rose. (Scarce.) 1'kt.75c.

\section{CERASTIUM BIEBERSTEINI}

Perennial. For rockeries and edging. Height 6 inches. R Pretty grey foliage growing in compact clumps with white flowers.

$$
\text { Oz. } \$ 3.00 \quad 1 / \text { oz. } \$ 1.00 \quad \text { Pkt. 25c. }
$$

\section{CHELONE BARBATA}

Perennial. Cutting and borders. Ileight 3 feet.

Trivett's Early Hybrids. New ! A splendid strain, similar in habit to the type but earlier and in a good range of pink, salmon, cerise, etc. In mixture. Pkt. 50c

\section{CHRYSANTHEMUM \\ Perennial}

The practice of raising Chrysanthemums from seed is now largely adopted by growers of this flower. From a sowing made in February fine plants can be obtained which will flower in the greenhouse or open border during the Autumn and new seedlings may frequently be secured.

\section{For the Greenhouse}

Trivett's Large Flow. Autumn Mixed. Saved from the finest varieties only. The seedlings will produce the widest possible range of colors in semi-double and single flowers.

\section{For the Open Border}

Trivett's Early Flow. Dwarf Mixed. A new strain which from a February sowing blooms freely in the open border in August. The plants attain a height of 2 feet and produce principally fine double flowers in white, yellow, rose, bronze, crimson, etc. Pkt. $75 \mathrm{c}$.

\section{CHRYSANTHEMUM}

\section{Annual, for cutting, display, etc.}

Single Coronet. (Illustrated.) Dwarf in habit, being only 18 inches in height. The beautiful cream flowers distinctly edged with lemon are indeed very dainty.
$\mathrm{Oz} . \$ 3.00$

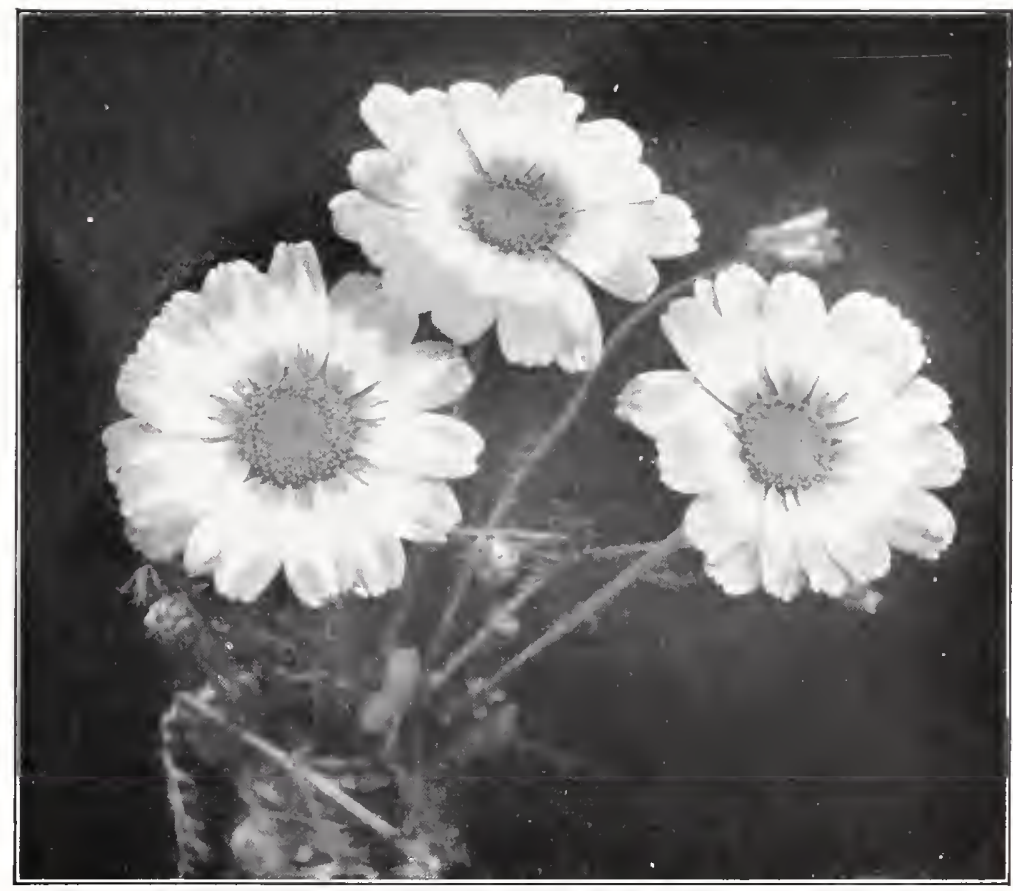

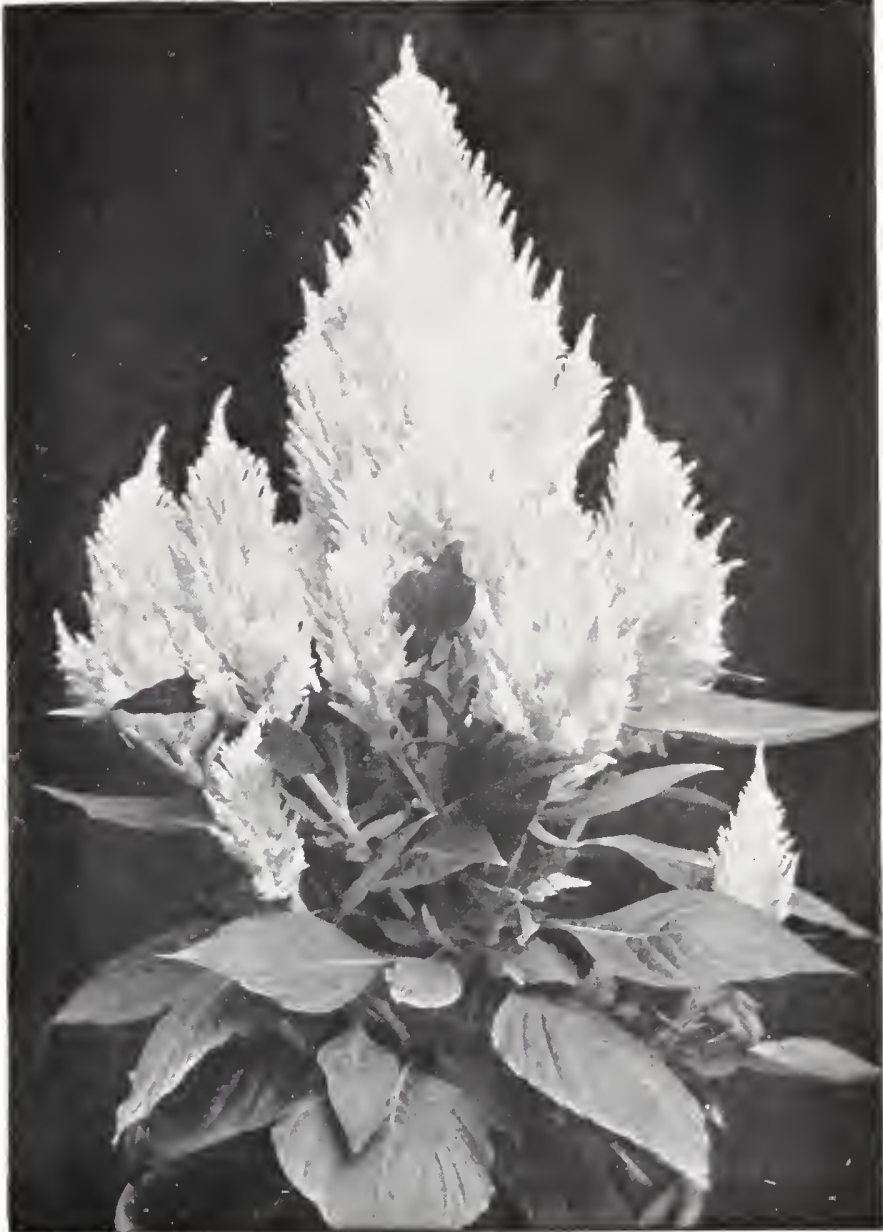

T.T.S. CELOSIA plumosa-Trivett's Yellow King 


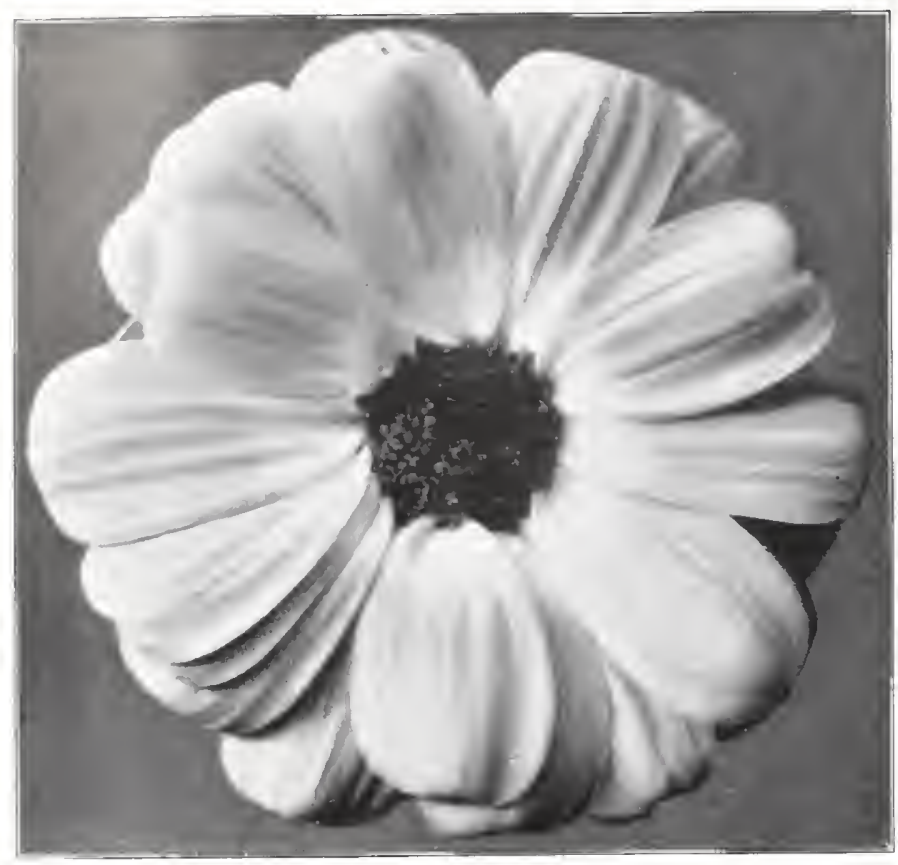

T.T.S.

CINERARIA sinensis-Rosamond

\section{CINERARIA}

Greenhouse flowering plant for pots and cutting.

Rosamond. (Sinensis type.) A delicate pink Cineraria of the giant hybrid type, with white center. The large, circular flowers usually display two rows of petals and attain a diameter of 3 to 4 inches.

Pkt. $\$ 1.50$.

Sutton's Forget-me-not Blue. This variety is of the intermediate type. The color is one of the prettiest shades in Cinerarias. Sutton's seed. Pkt. $\$ 1.50$.

The Duchess. Selected from the Feltham Beauty Star strain. Rich royal blue flower with a white center, a variety which immediately arrests attention. The few plants exhibited by Sutton $\mathbb{\&}$ Sons at the Chelsea Show last year were greatly admired. Sutton's seed. Pkt. \$1.25.

Many Flowered Salmon Rose. Without question the many flowered type is the finest for use as pot plants. We have pleasure in introducing two new colors this season.

Pkt. $\$ 1.00$

Many Flowered Crimson. Rich color. Pkt. $\$ 1.00$ For other colors, please refer to our General Seed Catalogue.

A full list of Cinerarias is offered in our General Seed Catalogue

\section{Corydalis chelianthifolia}

Perennial. For rockeries and edging. Height \& inches.

F Handsome, pale green, fernlike foliage over which D the spikes of clear yellow flowers are abundantly produced; a charming plant for rockery and dwarf borders.

Pkt. 75c.

\section{COLEUS THYRSOIDEUS}

Unique greenhouse perennial. For cutting.

A lovely species from central Africa, producing from November to February, graceful, bright blue flowers. Height $21 / 2$ feet. Pkt. $\$ 1.00$.

\section{COREOPSIS (Per. Calliopsis)}

Perennial. For borders and cutting. $31 / 2$ feet.

Mayfield Giant. A new variety from Australia, producing larger flowers than any other variety; rich golden yellow. Hardy perennial.

Pkt. 75c.

Double Lanceolata Grandiflora. An extra fine selection from the Single type. This variety produces handsome double and semi-double flowers of rich golden yellow.

$$
\text { Oz. } \$ 5.00 \quad 1 / 4 \text { oz. } \$ 1.50 \quad \text { Pkt. 50c. }
$$

\section{COSMIDIUM}

Annual. For cutting and display. 2 feet.

Orange Crown. The flowers are golden yellow with a broad circle of rich orange around the center disc. Produces a succession of blooms all Summer. Easily grown. Oz. $\$ 3.00 \quad 1 / 4$ oz. $\$ 1.00 \quad$ Pkt. $25 \mathrm{c}$.

\section{NOTE!}

The items offered in this catalogue are not listed in our General Seed Catalogue. 


\section{Cosmos}

Ammal. For cutting and display. 5 to b feet.

Trivett's Early Giant Mixed. A mixture of pink and white. Identical in height and habit, etc., to the late blooming Cosmos, but coming into bloom in August and continuing to flower until cut down by frost. This strain produces exceptionally large flowers and will, without doubt, take the place of the tall Autumn Cosmos. 5 pkts. $\$ 2.00$ Pkt. $50 \mathrm{c}$. Hollywood Star. A new departure in Cosmos, coming true to type. The flowers are unique in shape (see illustration) and are produced in pink, red and white, on long stems. We recommend this striking novelty. In mixture. Pkt. 50c. Baby Gold. A miniature Cosmos growing about $1^{1}{ }_{2}$ feet in height, forming neat, compact bushes and blooming very freety. The rich yellow, starlike flowers are very attractive on the deep olive green, finely cut foliage. Fxcellent cut flower.

Pkt. 25c.

$$
\begin{gathered}
\text { For other Cosmos, please refer to our } \\
\text { General Seed Catalogue. }
\end{gathered}
$$

\section{CYCLAMEN}

\section{Greenhouse flowering pot plant.}

\section{FISCHER'S GIANT EXHIBITION}

Fischer's "Master Cyclamen" are considered the superior of the many choice German strains.

Ruby Salmon. Exceptionally large blooms and freely produced. Unique shade. Pkt. (25 seeds) $\$ 1.50$. America. Golden salmon, the best of all the salmon shades. Pkt. (25 seeds) $\$ 1.50$. New Ruffled Salmon. The petals are ruffed and curled at the edges; rich, dark salmon color. Pkt. (25 seeds) $\$ 1.50$.

\section{OTHER CYCLAMEN}

Improved Perle of Zehlendorf. An improvement on this choice German variety; rich glowing dark salmon.

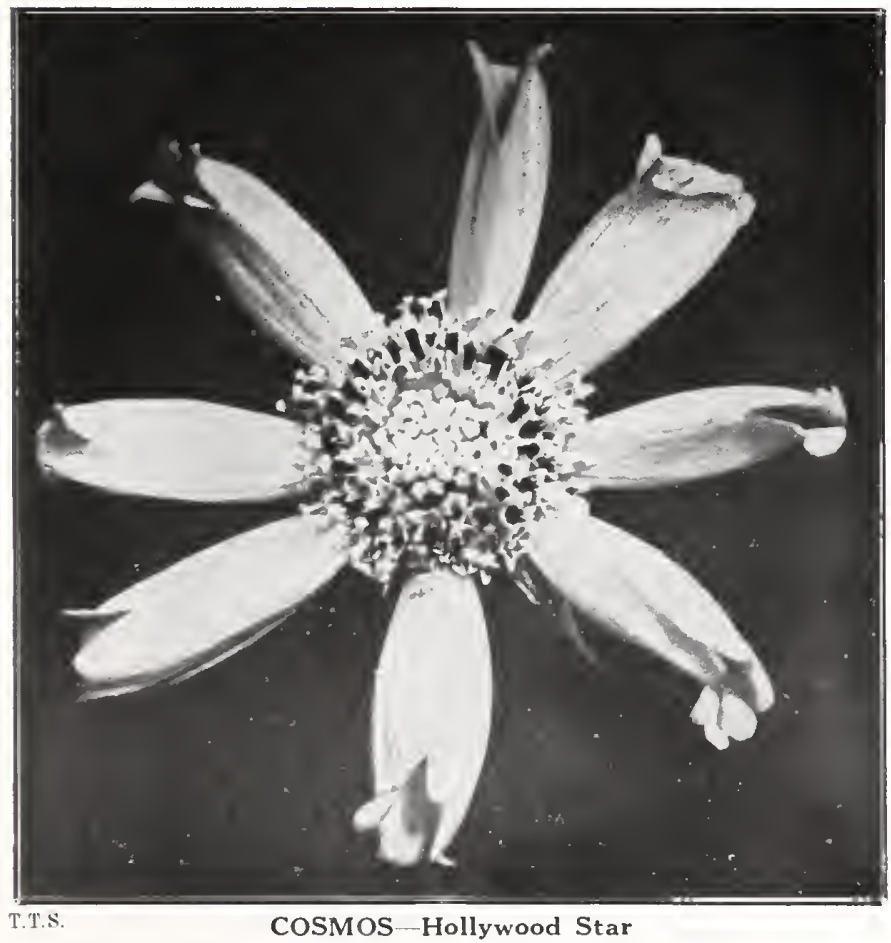

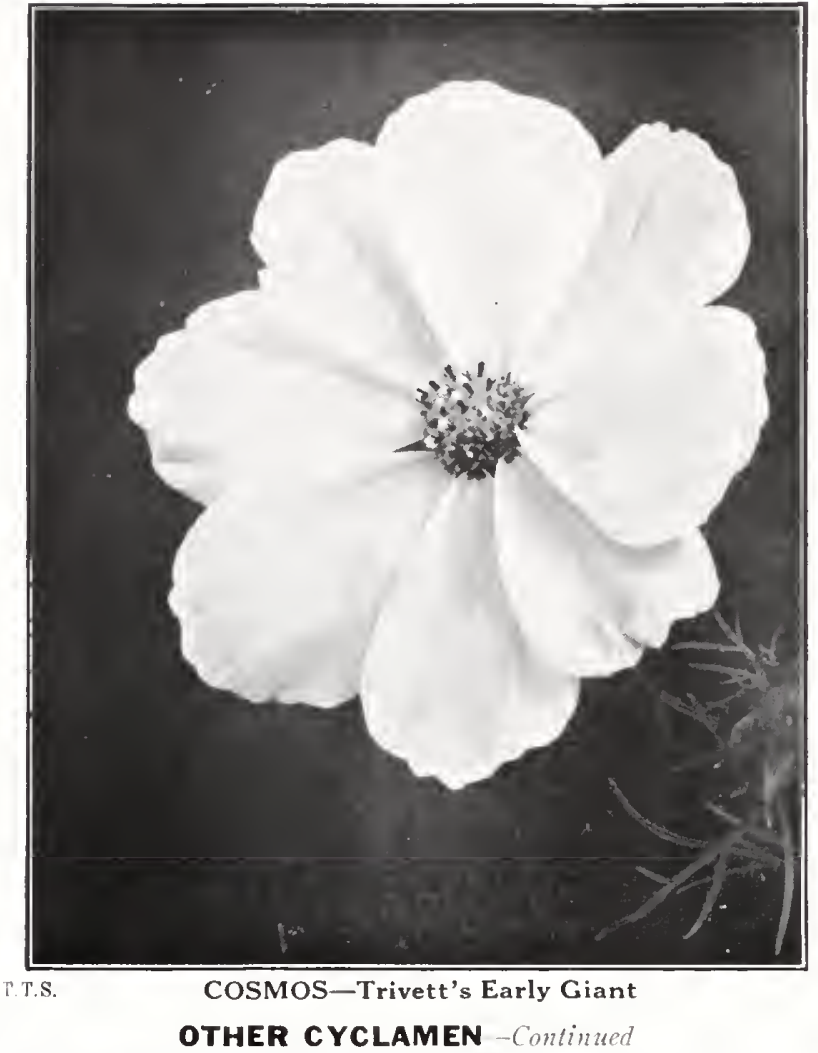

Improved Rose of Zehlendorf. Lovely delicate salmon shade.

Pkt. (25 seeds) $\$ 1.00)$.

Bush Hill Pioneer. Curious large feathered blooms in choice mixture. (Pkt. (25 seeds) $\$ 1.50$.

Sweet Scented. New! Strongly fragrant, giant flowers, white and rose shades mixed. Pkt. (25 seeds) \$1.25.

White Wonder. New English variety ; considered by many to be the largest and finest white. Pkt. (25 seeds) \$1.50.

Silver Leaf St. George. Beautiful silvery foliage, flowers salmon and crimson. Pkt. (25 seeds) $\$ 1.50$.

\section{DAHLIA}

Maxoni. Lost to cultivation, but now reintroduced. This wonderful Dahlia produces long, loose sprays of single rosy lilac flowers, very robust plants about 8 teet high. Grow in tubs placed outside; lift before frost and flower inside.

\section{CHR YSANTHEMUM-FLOWERED}

This new type produces many blooms 12 inches and over in diameter, in a wonderful range of beautiful colors, on strong, wiry stems. This is the strain from which to produce immense new seedlings. Pkt. (25 seeds) $\$ 2.00$.

Apoldro. (Zimia Flowered.) Makes a brilliant effect in beds or borders. The plants are dwart and compact and throw up in great profusion semi-double blooms of crimson scarlet with rich golden center. An excellent plant for Summer and Autumn bedding. Pkt. $75 \mathrm{c}$.

Coltness, Yellow Gem. Single clear rellow coming 70 to $80 \%$ true from seed. Pkt. 50c.

For other Earieties of Dahlias from seed, please refer to our General Seed Catalogue 
We have great pleasure in offering seed of these wonderful new Super Delphiniums in separate varieties. The seed we offer has been carefully hand saved by an English Delphinium specialist - the finest procurable. It should be understood that named varieties of Delphiniums do not reproduce themselves entirely true from seed. All the seedlings will be good however. Sow seed in Spring.

\section{TREATED $\mathcal{O}$ SEEDS}

\section{ALL DELPHINIUM SEEDS SOLD BY US ARE} TREATED AGAINST SEED-CARRIED DISEASES

The enormous Giants recently developed from the original Wrexham or Hollyhock strain - the World's Best, to date.

Advancement. The real super Delphinium; positively the last word in the new Giants. Advancement marks a great achievement in Delphinium creation. There is often 5 feet of solid bloom of clear electric blue with pale mauve center. 7 to 8 feet.

Pkt. $\$ 5.00$

Anne Hathaway. A lovely lady in dazzling blue, with attractive white eye; magnificent spikes 5 to 6 feet high.

Pkt. $\$ 3.00$

Afghan Queen. Charming pale blue, single sort; a light khaki eye completes a refreshing color scheme; very large spikes. 5 feet.

Pkt. $\$ 5.00$

Clive Greaves. Rich porcelain blue flowers of good size and form, on a long, tapering spike of imposing stature. 5 feet.

Pkt. $\$ 2.50$

Great Strides. Beautiful pale blue shaded with pinkish mauve; a grand flower.

Pkt. $\$ 2.00$

Happy Thought. Mid-blue shaded with Pansy Violet. Height 5 feet; a striking beauty.

Pkt. $\$ 2.00$

Monarch of Wales. A. M., R. H. S., Wisley Trials. The raiser's most famous variety; gigantic spikes of deep blue and mauve; 5 to 6 feet high.

Pkt. $\$ 2.00$

Mrs. A. J. Watson. 7 feet high with solid flower spike $31 / 2$ feet long; deep mauve with black center; enormous.

Pkt. $\$ 2.00$

Mrs. Jessie Oldham. Pale sky blue shaded and deeply suffused with pink; tall and massive spikes. 6 feet. Pkt. $\$ 2.00$

Mrs. Townley Parker. Produces a fine spike of large, single sky-blue flowers with white eye. A. M., R. H. S. 4 to 5 feet.

Pkt. $\$ 2.00$

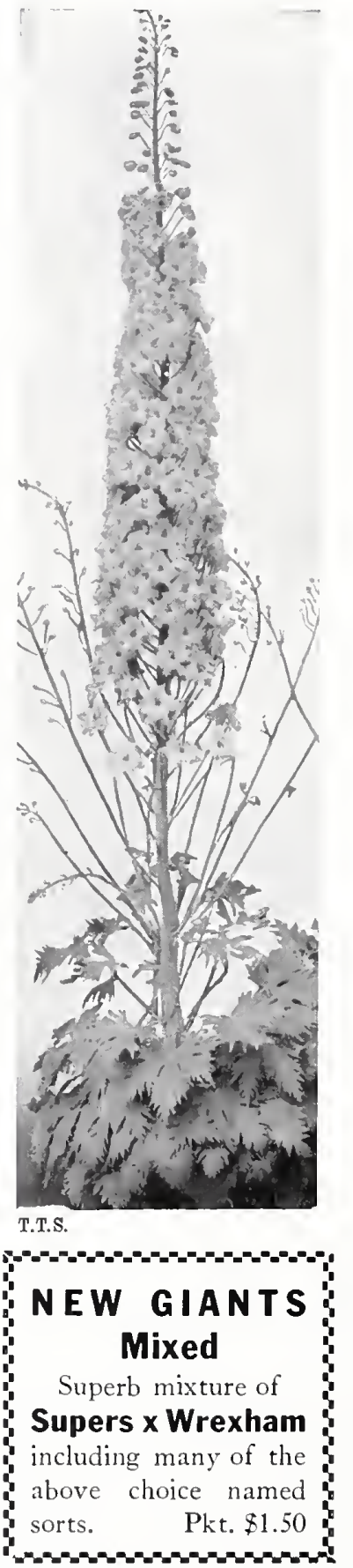

Norah Phillips. A truly marvelous spike which was greatly admired in the raiser's group at Bath, England. A gorgeous effect of deep blue and purple florets on a tapering spike 6 feet high, $4 \frac{1}{2}$ feet being in solid bloom. Truly a great variety.

Pkt. $\$ 2.00$

Princess Elizabeth. Another charming variety, the guard petals are of gentian blue, inner petals of the same shade but tinted with pure maure. A small black eye gives a charming "set-off" to the flower. $t$ to 5 feet.

Pkt. $\$ 2.00$

Rose Marie. A. M., York, England. Rich Pansy violet, 5 to 6 feet in height. Makes splendid contrast to the lighter shades.

Pkt. $\$ 2.00$

Superb. A grand spike, bearing flowers of a light mauve shade, the eye being maure with touches of honey yellow on the edges. 5 feet.

Pkt. $\$ 2.00$

St. George. A long tapering, dainty spike of rich Reckitt's blue, with black eye; one of the few real true blues we have in this new race. 5 feet. Pkt. $\$ 2.00$

The Bishop. Bright royal blue with large, conspicuous white eye. A greatly improved Rev. E. Lascelles. One of the most outstanding varieties. Height 4 to 5 feet.

Pkt. $\$ 2.00$

Warwick. Lovely waved flowers of deep blue and plum purple. Huge spike of unique form. Height 6 feet; a novelty of great merit.

Pkt. $\$ 3.00$

Will. Shakespeare. Monstrous tapering spike; 4 feet of solid bloom; lovely pale blue with dark eye. Height 6 feet.

Pkt. $\$ 3.00$ 


\section{DIANTHUS \\ PERENNIAL SORTS}

Highland Queen. The most brilliant perennial Dianthus in cultivation, bearing in profusion flowers of a lustrous vermilion scarlet color, which captivates the beholder at first sight. It is extremely hardy, of vigorous growth and ideal for bedding, borders, and the rock garden, continuing in bloom from the end of May until November. Illustrated.

$$
5 \text { pkts. } \$ 2.00
$$

Pkt. 50c.

Allwoodi Alpinus. A grand novelty; a new hybrid a race of Dianthus. Height 4 to 6 inches. Perennial. IS Single and semi-double flowers in beautiful mixture. Ideal for rockeries, etc.

Pkt. $\$ 1.00$.

See also Dianthus allwoodi in our General Catalogue.

\section{ANNUAL DIANTHUS}

Trivett's Double Lilac. Unusual shade, double flowers of lilac becoming darker toward the center. Splendid cut flower. Nakes a charming combination with Trivett's Double Cream.

Pkt. 50c.

Trivett's Double Cream. Another uncommon shade in annual Pinks, pale straw or cream yellow. Contrasts well_with Trivett's Double Lilac.

Pkt. 50c.

Trivett's Double Picotee. Charming shade of light strawberry pink, nicely fringed, large double flowers, the petals are daintily edged with white.

For other warieties of Dianthus, please refer to our General Seed Catalogue

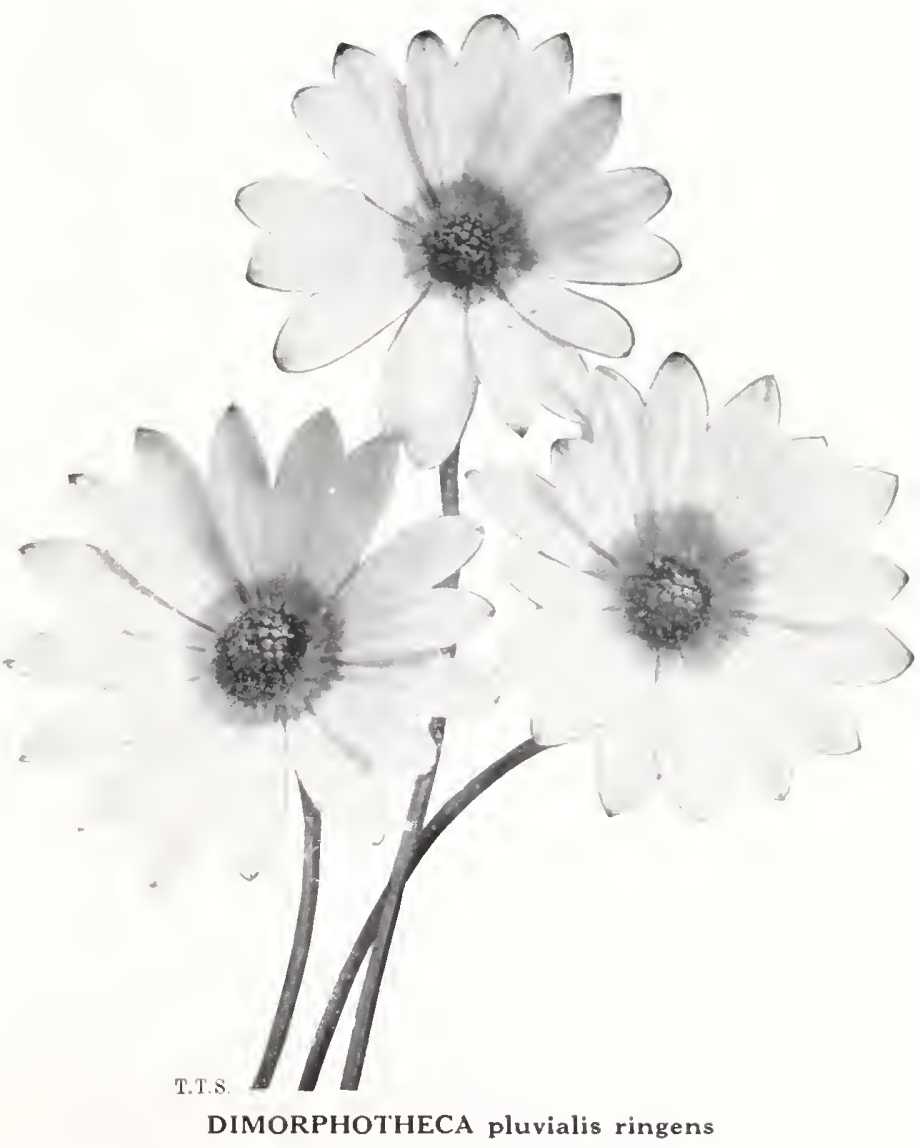

\section{DIMORPHOTHECA}

Annul. For cutting and display. Height 1 foot.

Lemon Queen. Brilliant lemon colored flowers well set off by the blue black central zone. Pkt. 50c.

Pluvialis Ringens. (Illustrated.) Pure white, with attractive blue center zone; fine for cutting. Pkt. 50c.

Salmon Beauty. Aurantiaca type; true salmon shade. $\quad$ Oz. $\$ 4.00 \quad 1 / 4 \mathrm{Oz} . \$ 1.25 \quad$ Pkt. $50 \mathrm{c}$

\section{DRACAENA INDIVISA}

Greenhouse ornamental Stoveplant.

Handsome foliage plant which can be grown from seed. Useful as a pot plant in greenhouse and for center of summer beds, in garden rases, etc.

$$
\text { Oz. } \$ 3.00 \quad 1 / 40 z . \$ 1.00 \quad \text { Pkt. } 35 \mathrm{c} \text {. }
$$

\section{EPILOBIUM ANGUSTIFOLIUM French Willow or Rosebay)}

Perennial for tall borders and groups. Ileight 3 feet.

Excellent plant for the rear of herbaceous borders and wild gardens. Flowers bright rose, in long loose sprays.

$$
\text { Oz. } \$ 3.001 / 4 \text { oz. } \$ 1.00 \quad \text { Pkt. } 25 \mathrm{c} \text {. }
$$

\section{ERIGERON DIVERGENS}

\section{Ammal. For display in borders. Height 15 inches.}

This very pretty annual species forms neat, freely branching, shapely bushes about 15 inches ligh which are thickly strewn with small white flowers shaded with lavender. Of great value for planting in clumps in the annual border. Easily grown. Pkt. 50c. IN GENEROUS OVER-SIZE PACKETS 


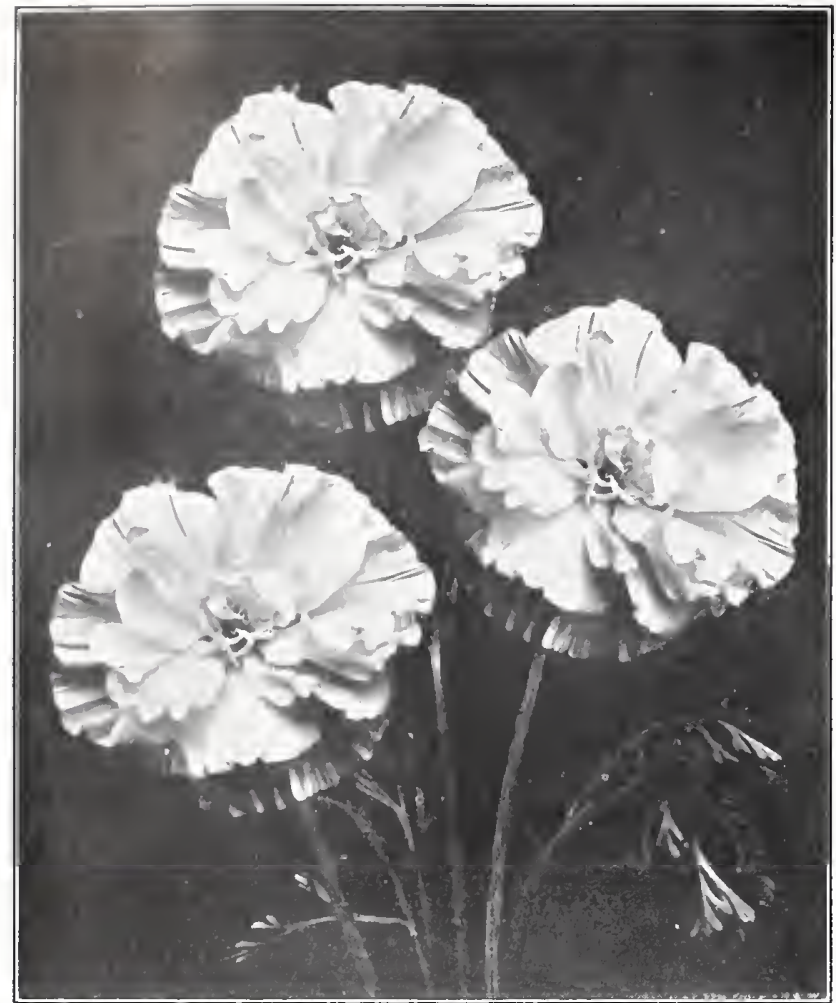

T.T.S.

ESCHSCHOLTZIA-Buttercup

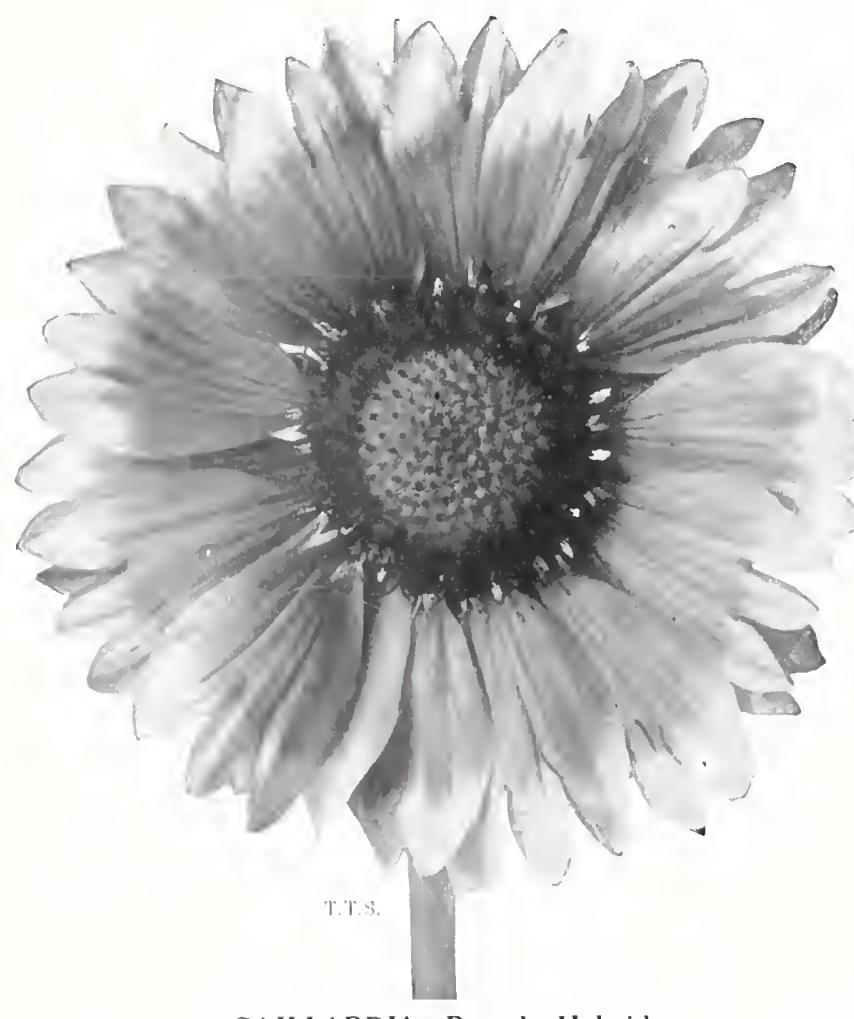

GAILLARDIA - Portola Hybrids

\section{ESCHSCHOLTZIA}

Annual. For cutting. Height 15 inches.

Buttercup. Lovely new sort, double flowers, beautifully caniculated, of the desired soft butter yellow. Illustrated.

Pkt. 50c.

Trivett's Raspberry Red. New, double flowering sort. The color is a delightful shade of raspberry red. The beautifully formed blossoms on good, strong stems make this variety an ideal cut flower.

Pkt. 75c.

Trivett's Double Orange. New, double flowers of exquisite form, artisticall: caniculated petals. The color is rich glowing orange.

Pht. 50c.

\section{ROCK ESCHSCHOLTZIA}

Eschscholtzia, Lilliput. R A lovely little annual for rockwork and edging. The plants do not grow more than 4 to 6 inches high and are covered with small pale, lemon colored flowers. Pkt. 35c.

\section{EUCALYPTUS}

Greenhouse ornamental perennial.

Globulus. (Blue Gum Tree.) Admirable for subt:opica! bedding or greenhouse decoration. Pkt. $25 \mathrm{c}$.

Citriodora. Leaves delightfully lemon-scented. For greenhouse decoration.

Pkt. 50c.

\section{EUPATORIUM (Mistflower)}

Perennial. For borders and cutting. Height 2 feet.

Coelestinum. Heads of light blue flowers like a glorified Ageratum; good stems for cutting; blooms profusely from September to October.

\section{EUTOCA VISCIDA}

\section{Annual. For cutting and display. Height 1 foot.}

Profuse blooming annual. Easily grown, bright blue flowers, suitable for bees. Oz. $\$ 1.50^{1} / 4$ Oz. 50c. Pkt. $15 \mathrm{c}$.

\section{EXACUM MACRANTHUM}

Greenhouse pot plant. Height $1 \frac{1}{2}$ feet.

Magnificent and unusual plant. Bright violet flowers with golden anthers.

\section{FELICIA BERGERIANA}

\section{Annual. For general display.}

Tufted grasslike foliage from which are thrown masses of small, star-shaped flowers of an uncommon shade of blue. A really pretty annual of unique beauty. Easily raised from seed.

\section{FRANCOA RAMOSA (Bridalwreath)}

Greenhouse perennial. For cutting. Meight $21 / 2$ feet.

Popular decorative plant which is of the easiest possible greenhouse culture. During the Summer mon ths it produces a number of elegant sprays of pure white flowers. Excellent for cutting and very largely used for table decoration. Pkt. 50c.

\section{GAILLARDIA GRANDIFLORA}

\section{Perennial. For borders and cutting. Height $21 / 2$ feet.}

Bremen. The bushy plants $21 / 2$ feet high are covered with long-stemmed blossoms of deep coppery scarlet with dark brown disc. The petals are tipped with yellow, the flowers measure about 3 inches across and resemble those of our magnificent annual Gaillardia Single Salmon (see our General Catalogue) and recently christened Indian Chief. If sown in March, G. BREmen will flower during the first season. Pkt. 50c.

Portola Hybrids. A grand varied strain of perennial Gaillardia, embracing many new shades and combinations. Bold large flowers. Oz. $\$ 4.00 \quad 1 / 4$ oz. $\$ 1.25 \quad$ Pkt. 50c. 


\section{GENTIANA HASCOMBENSIS}

This beautiful new Gentian was raised by Mr. C. T. Musgrave and is a cross between $G$. lagodechiana and $G$. septemfida var. cordifolia. The individual Howers are large-about $11 \%$ inches across and of bright, mid-blue, slightly speckled with white toward the hase. The flowers are produced in a bunch or truss on a stem about 11.2 feet high. The flowering period is from early fuly until end of August. The seed can be raised in heat in spring, but the best results are abtained by sowing in Autumn and keeping the pans in a coldframe. The seed will then germinate in the following Spring. l'erennial.

\section{GERANIUM TRAVERSI}

Perennial. For rock gardens, etc. Height I foot.

$\mathbf{R}$ A beautiful plant introduced from New Zealand. It has a B spreading habit, woolly silvery grey foliage and bright pink flowers. Splendid hardy plint for the rock garden. . Pkt. $75 \mathrm{c}$.

\section{GERBERA (Transvaal Daisy)}

Greenhouse flowering plant. For cutting. Height 15 inches.

Trivett's Double Hybrids. Nerw. The double form of the popular G. jamesoni Hybrid in a splendid range of choice colors and shades.

Pkt. (10 seeds) $75 \mathrm{c}$.

\section{GESNERIA (Naegelia)}

Greenhouse decorative flowering plant. Height 18 inches.

Hybrids Mixed. A delightful race of Hybrid Gesnerias for the decoration of greenhouse and conservatory. The flowering spikes carry mumerous bright pendulous blooms including white, yellow, salmon, orange, crimson, etc. Valuable table plant. Pkt. \$1.00

\section{GILIA}

Biennial. For display, decoration etc. Height $t$ feet.

Coronopifolia, New Hybrids. A magnificent strain of this lovely plant, producing long spikes of the most brilliant flowers interspersed with fine Larkspur-like foliage. The colors include vermilion, salmon, apricot, pink, yellow etc. Succeeds best treated as a half harty annual (See photograph.) ... ... Pkt.75c.

Californica. New. Shrub-like perennial, 3 feet in height, with spikes of bright pink, Phlox-like flowers. Makes a rare pot plant for greenhouse culture or may be used in the border with a little Winter protection.

Pkt. $75 c$

\section{GLOXINIAS}

Greenhouse flowering pot plant.

These exquisite flowers may easily be raised from seed at small expense, as only a limited amount of heat is required. If the seed is sown in April, the plants will start blooming in the following dugust or September.

\section{SUTTON'S VARIETIES}

We do not know of any superior sorts to offer our customers. Her Majesty. (Sutton's Seed.) 'This exquisite Gloxinia is still unsurpassed by any other white variety. The flowers are as pure as newly fallen snow and are borne on short stems. just clear of the elegant foliage. The plant is compact, free Howering and of highest decorative value.

Pkt. $\$ 1.25$

King George V. (sutton's seed.) A bright scarlet crimson variety which has been much admired. The nassive flowers, which are of the largest size are perfect in form and show to great advantage over the beautifully recurved foliage.

Duchess of York. (Sutton's Seed.) Flowers of a rich $\$ 1.25$ blue, each petal edged with a broad band of white. A striking and lovely variety. ... ... . ... Pkt. 1.25

Meteor. (Sulton's Seed.) Large, fringed bright scarlet flowers, giving a very light and pretty effect. Pkt.\$1.25

Pink Beauty. (Sutton's seed.) A very elegant (jloxinia with a deep band of rose pink to the white throat. Pkt.\$1.25

Azure Blue. (Sutton's Seed.) Flowers exquisitely tinted with sky blue on a white ground. A very lovely shade.

\section{GUNNERA MANICATA}

Pikt. $\$ 1.25$

Perennial. Foliage or omamental plant. lleight 5 feet.

A noble plant with immense leaves about + feet in diameter. Requires a damp situation. A fine subject for lawns, the bog garden and beside pools.

Pkt. $50 \mathrm{c}$

\section{GYPSOPHILA (Babysbreath)}

Elegans Crimson. A rich colored variety of anilin red, of the same habit an the popular Ammal th hite. Hxcellent for mixing with cut flowers requiring color. Annual. Oz. $90 \mathrm{c} .1+0 z .35 \mathrm{c}$. Pkt. $15 \mathrm{c}$.

Paniculata, Double Hybrids. This is a double selection of the perennial Gypsophila, but in various shades of color. Height 3 feet. Perennial. ... Pkt. $\$ 1.00$

Paniculata, Double Snowflake. New, early flowering improved double white perennial variety. ... Pkt. $75 \mathrm{c}$. 


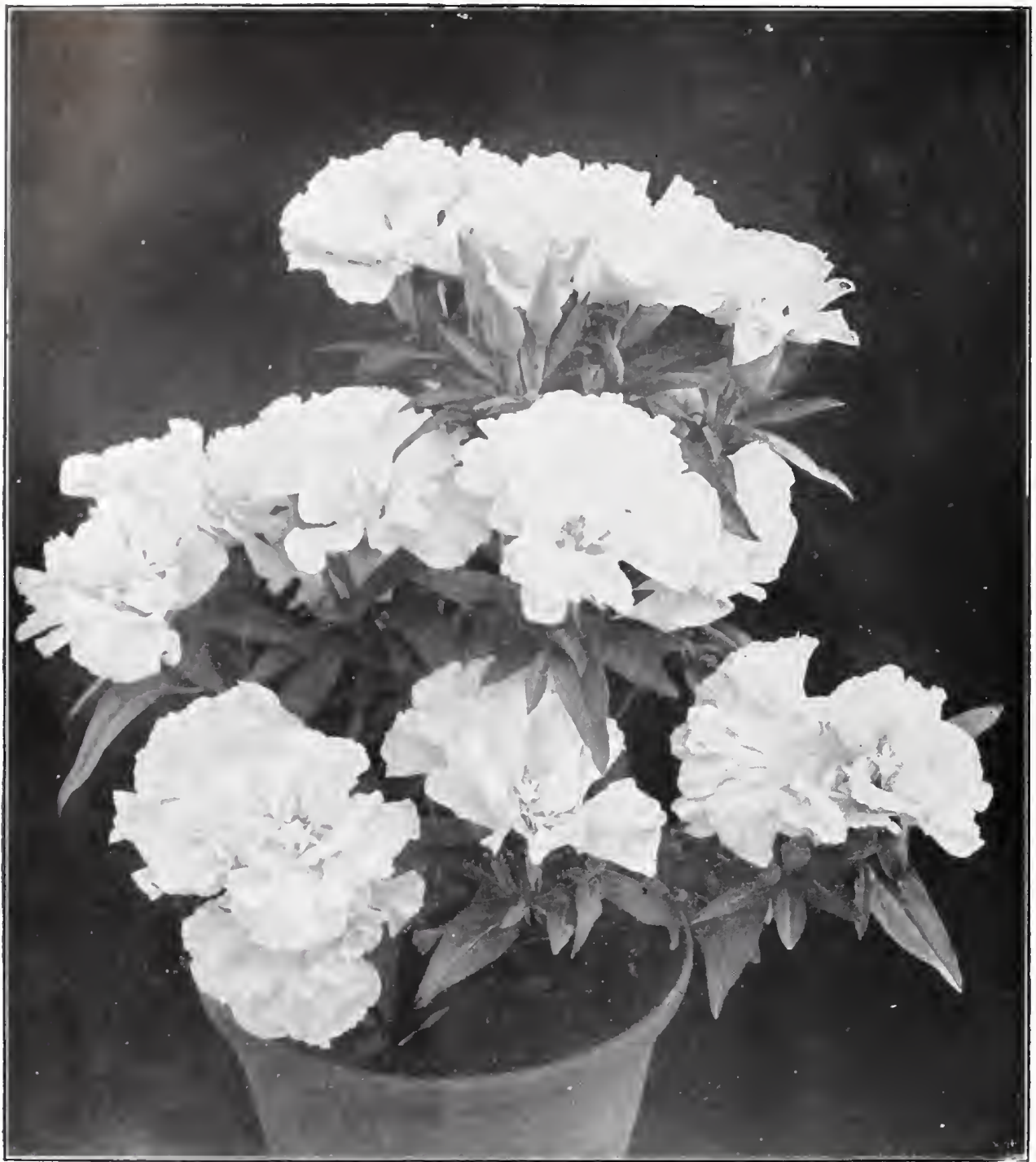

T.T.S

NEW GODETIA - Trivett's Pink Azalea

\title{
TRIVETT'S GODETIAS
}

Amual. For cutting, display, bedding and pots. Easy to grow. Treat like Marigolds, tetunias, lierbenas, etc.

DWARF AZALEA FLOWERED (Height 1 foot)

A new development which will become very popular, as will be seen from our photograph herewith. The habit of the plant and the way the flowers are borne above the foliage makes it resemble, to a remarkable degree, the Azalea. The blooms, however, are much larger and produced in such abundance that the foliage is almost completely hidden when the plant is at its best. One can easily picture the extraordinary effect this plant would make if bedded en masse, planted in clumps in annual borders. As a pot plant it has a great future. Our Dwarf Azalea FloweredGodetia is of the easiest culture, prefers ordinary soil. Do not feed.

Trivett's Pink Azalea. Double flowers of the brigh test shell pink or pale salmon pink without any marking whatsoever. 'True double Azalea Howered. 5 pkts. $\$ 2.00 \quad$ Pkt. 50c.

Trivett's Rose Azalea. Iivid rich rosy pink with darker center. True louble Azalca habit. 5 pkts. $\$ 2.00$ Pkt. 50c.

Trivett's Crimson Azalea. Bright deep crimson, attractive douhle flowers which are produced in abundance, almost hicling the foliage. Splendid for bedding or as a pot plant. 5 pkts. $\$ 2.00$ Pkt. $50 \mathrm{c}$.

\section{HEBENSTREITIA}

COMOSA

Introduced from Africa, producing innumerable small, white flowers on a long, slender $\mathrm{Mi}-$ gnonette-like spike and bright orange blotches make them very interesting. Succeeds well as an annual. Night scented. Height $11 / 2$ feet. $\ldots . .$. Pkt. 50c.

\section{HELIOPHILA}

LINEARIFOLIA

A charming new annual from South Africa with pretty blue, white eyed flowers, which are freely produced in long, graceful sprays. Will make a striking effect if interspersed with the yellow Ursinia. ... Pkt. $75 \mathrm{c}$.

\section{HIERACIUM}

VILLOSUM

Perennial. For rockeries and borders. 1 foot.

- An excellent subject for rockeries and perennial borders; dense, downy foliage above which rise the showy, golden yellow flowers. Pkt. 50c

\section{HELICHRYSUM (Everlastingflower)}

Annual. For culling and drying or Winler.

Trivett's Pink. A new shade, beautiful, delicate light pink. In size the blooms are exceptionalover 2 inches in diameter. Oz. $\$ 4.001 /$ oz. $\$ 1.25$ Pkt. 50c.

\section{HOLLYHOCK}

New Type
Perennial. For display. Heigh 5 feel.

Trivett's Triumph. A new tripe of Hollyhock, being of branching habit, producing many flowering stalks studded with exquisitely fringed, double flowers and in the widest range of colors and shades heretofore unknown in Hollyhocks.

\section{TALL DOUBLE GLADIOLUS FLOWERED}

\author{
Height $21 / 2$ feet)
}

It would be difficult to offer our customers a more uncommon, beautiful and useful cut flower which is so easily raised from seed. Treat similar to hardy annuals, such as Cosmos, Zinnias, etc. Our tall Godetias remain in full beauty for a long period and when cut, the long, graceful sprays make a handsome decoration for vases. As a greenhouse cut flower, quick growing and easy to raise, it has few equals. Prefers ordinary soil

Trivett's Tall Cherry Red. A beautiful rich cherry red color; the exquisite double flowers are arranged in long, graceful sprays; invaluable for cutting. 5 pkts. $\$ 2.00$ Pkt. $50 \mathrm{c}$.

Trivett's Tall White. A new Godetia with glistening pure white double flowers. Makes a delightful contrast to our Cherry Red or the Shell il ink. 5 pkts. $\$ 2.00$ Pkt. 50c.

Trivett's Tall Shell Pink. Charming new color daintily frilled double flowers on light, grace ful, Gladiolus-like spikes. A choice and uncommon cut Hower. 5 pkts. $\$ 2.00$ Pkt. 50c. 


\section{HYPERICUM reptans}

perennial. For rock gardens. Trailing.

A gem for the rock garden. Of trailing habit with slender evergreen foliage over which the bright yellow flowers show to great advantage. ....... Pkt. $75 \mathrm{c}$.

\section{IPOMOEA (Convolvulus)}

Annual. Climber. Height about 8 feet. Delights in a sunny position.

Trivett's Early Heavenly Blue. Nuch earlier Howering than the ordinary Heavenly Blue (Rubro caerulea) and more free Howering. Supplies an abundance of large, sky blue Howers three or four months after sowing. Admirably adapted for verandas, trellis work, outside breakfast rooms, etc. Must have a sunny position. Also admirable for greenhouse decoration.

Oz. $\$ 3.001 / 1$ oz. $\$ 1.00 \quad$ Pkt. 35c.

KOCHIA (Summer Cypress)

Ornamental foliage plant. 3 feet.

Trivett's Pyramid. We here offer our customers an entirely new and greatly improved Kochia trichophylla. The plants are much more branching than the type, forming beautifully shaped pyramidal bushes thickly covered with light, feathery green foliage which turns to a rich crimson in the Autumn. Pkt. $75 \mathrm{c}$.

LARKSPUR TREATED SEEDS Annual. For culting. Height 4 feet. Trivett's Salmon Pink. Improved strain of Los Angeles. In this new variety we have the same delightful salmon pink as in "La France" but overlaid with a brilliant rose, creating a more brilliant and deeper shade. The foliage is a darker green. The color of Trivett's Salmon Pink is particularly lovely under artificial light. Illustrated.

Oz. $\$ 5.00 \quad 1 / 1 \mathrm{oz} . \$ 1.50 \quad$ Pkt. 50c.

Trivett's La France. The beautiful new sort which has proven so desirable. Lovely salmon pink resembling the popular Antirhinum, Fennie Schneider. A lighter pink companion to Trivett's Salmon Pink, and having the same tall, upright habit of growth yet producing many lateral spikes for cutting.

Oz. $\$ 3.00$ 1/1 0z. 85c. Pkt. 30c.

Trivett's White Spire. A new, dazzling pure white Larkspur with the improved upright habit of La France, making it without question the finest white variety yet introduced. Oz. $\$ 3.001 / 4$ oz. 85 c. Pkt. 30c.

Los Angeles. See Trivett's Salmon Pink.

\section{LATHYRUS pubescens}

Greenhouse perennial Sweet Pea.

Beautiful everlasting Sweet Pea from the Argentine; racemes of lovely pale blue flowers.

$\$ 1.00$

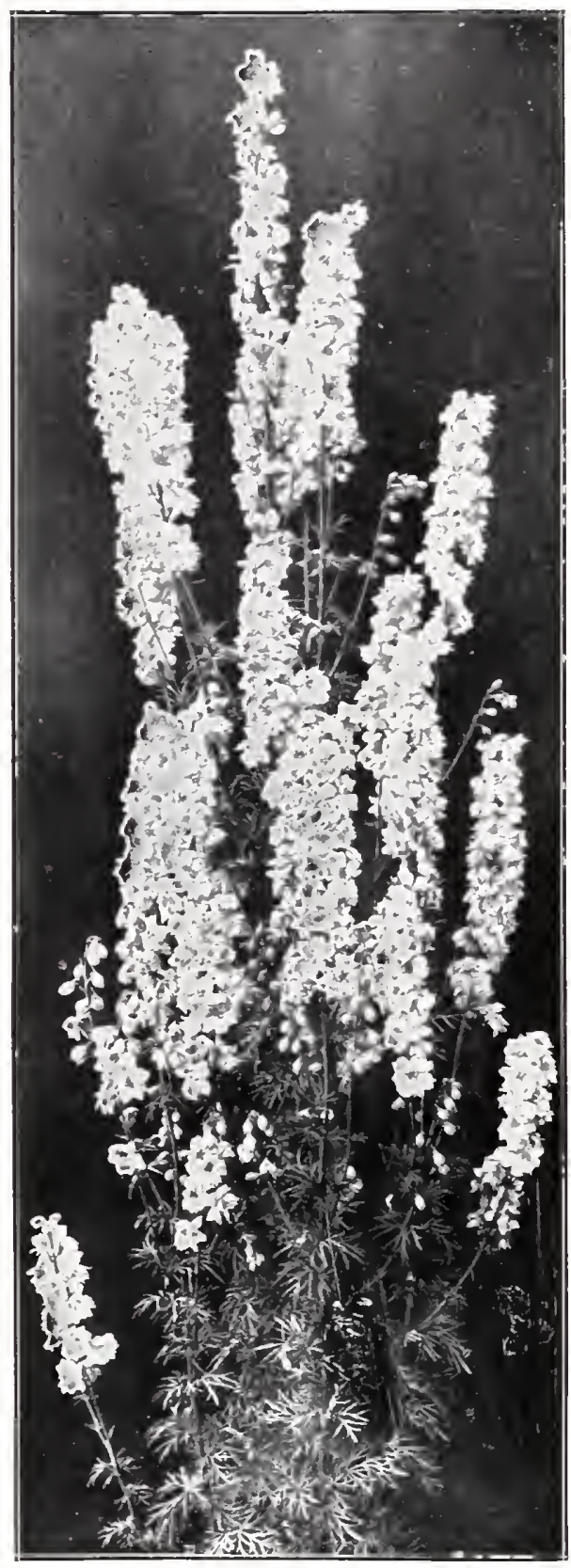

NEW LARKSPUR

Trivett's Salmon Pink

LIATRIS Ferennial. For borders, etc.

Scariosa alba. Introduced by us in 1929 through the courtesy of a gardener friend. Very useful for rock gardens, for perennial borders and as a cut flower. Blooms from middle of September until October 15th. ... ... ... Pkt. 50c.

Pycnostachya. Tall growing noble species, 4 to 5 feet high, producing tall, strong Eremurus-like spikes densely covered with purple bloom which flowers for a long time. Excellent for massing in the background of herbaceous borders or in clumps against evergreens, etc. As a cut flower try a few spikes with orange Gladiolus or yellow trican Marigolds.

Oz. $\$ 3.00 \quad 1$ oz. $\$ 1.00 \quad$ Pkt. 35c.
LINARIA alpina

Perennial. For rock and alpine gardens. 6 inches.

R Elegant, purple flowers blotched A with orange resembling miniature Antirrhinum. Abundantly produced on trailing plants with greyish green foliage. Blooms in Summer and Autumn. Height 6 inches. Pkt. 50c.

\section{LOBELIA cardinalis}

Perennial. For display. Iteight 5 feet.

The Bishop. Magnificent strong spikes of glistening vermilion scarlet. lward of Merit, R. H. S. 1929.

\section{LUPINS}

\section{HARKNESS" "Regal" LUPINS}

The finest and most up-to-date strain of perennial Lupins.

Harkness Sons of England have received the following awards for their magnificent strain of Lupins.

Silver Cup at the Great York Gala, England, for the best competitive exhibit in the entive show.

75 Guinea Trophy for the best new race of plants.

Award of Merit R. H. S. Award of Merit, R. A. S. and many other cups, gold medals and first prizes.

The following Collection is unique!

Carrie Tonks. Apricot with yellow.

Cleopatra. Flame and yellow.

Eva Thorpe. Apricot with fawn.

Fortunata. Soft pale apricot.

Gold Crest. Bronzy yellow

Golden Gate. Rich golden yellow.

Golden Thoughts. Rosy fawn.

Joy. Splendid pink and yellow.

Lady Greenall. Choice a pricot self.

Marjorie. Bronze shaded yellow.

May Robinson. Apricot and rose

Queen of Hearts. Pink and white.

Any of the above named sorts,

Oz. $\$ 6.00 \quad 1_{4}$ oz. $\$ 2.00$ Pkt. $50 \mathrm{c}$.

\section{SPECIAL COLLECTION}

One packet each of the above 12 superb sorts, separate. ... $\$ 5.00$ $1+\mathrm{oz}$. each of 12 sorts. ... $\$ 20.00$ Tote! For Harkness's Lupins llixed and other types and colors including the blue shades, please refer to our General Catalogue.

\section{LYCHNIS}

Pereminal. For rockeries. Height t inches.

Alpina. Prettr plant for the rock garden; produces clusters of brilW liant rose colored Howers during Spring. Pkt. 50c.

Forresti Hybrids. Rare shades of carmine, crimson, pink, white, etc. Forms bushes 2 feet across and $11_{2}$ feet high with panicles of Howers on stems 15 inches long. Hardy perennial, valuable for display and chtting. 


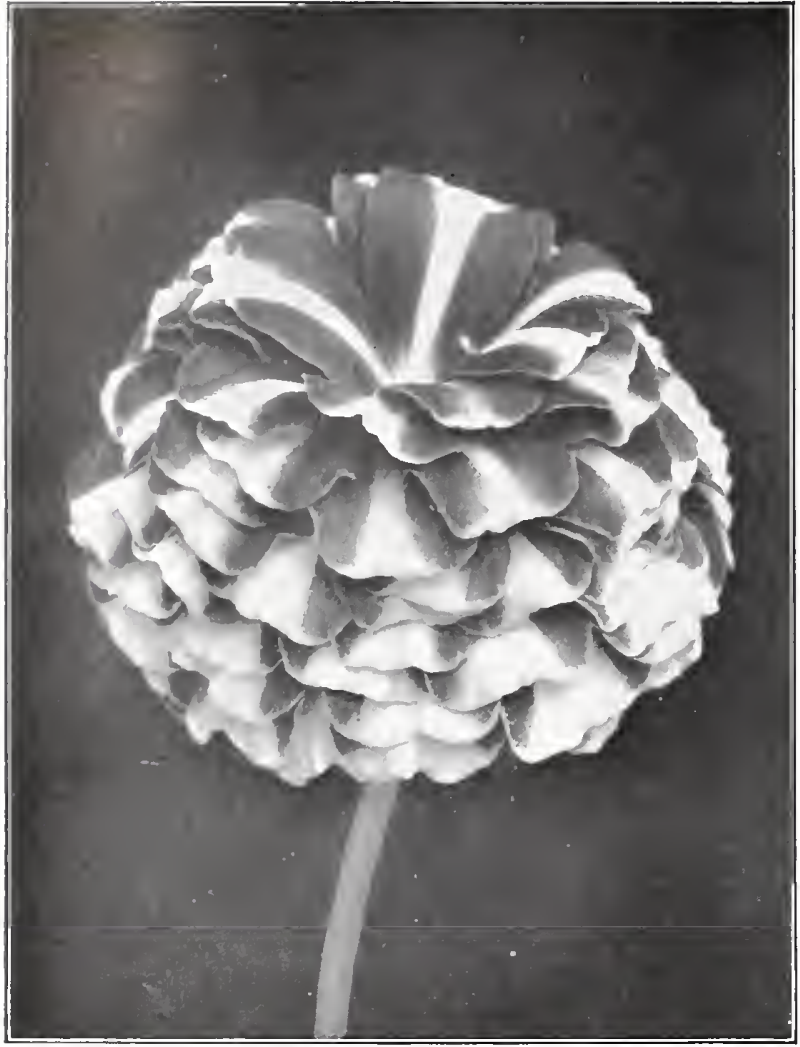

MARIGOLD-Trivett's Special Striped

\section{NOLANA GRANDIFLORA}

Annual. For sunny rockeries, etc. Height 6 inches.

A vigorous growing hardy Annual giving a mass of pale lavender blue, bell-shaped flowers with white throats. The plants spread freely. Very useful for covering bare places, providing the position is sunny and the soil light. Easily grown.
Oz. $\$ 1.50$
$1 / 4$ oz. $50 \mathrm{c}$.
Pkt. 15c.

\section{OENOTHERA (Evening Primrose)}

\section{Biennial. For general garden display.}

Clutei. New! This handsome biennial Evening-primrose forms a large rosette of leaves from which it throws up a stout central stalk 4 feet in height, bearing in great profusion large flowers of soft yellow shade. Does not close the petals during the day and is very effective in large masses in borders and wild gardens.

$$
\text { Oz. } \$ 6.00 \quad 1 / 1 \text { oz. } \$ 1.75 \quad \text { Pkt. } 50 \text { c. }
$$

Trichocalyx. Another fine, new sort which also does not close its flowers during the day. The plant grows about 15 inches high, bearing a number of blooms that follow each other in continuous succession. These are large, of purest white and adorned with beautiful golden anthers.

$$
\text { Oz. } \$ 6.00 \quad 1 / 4 \text { oz. } \$ 1.75 \quad \text { Pkt. } 50 c \text {. }
$$

\section{OXALIS ROSEA}

Attractive bright pink, suitable for pots, hanging baskets, etc. Seed sown indoors in March will bloom in May. Height 6 inches.

\section{MARIGOLD} Pkt. 50c.

Thivett's Special stripeday.

Trivett's Special Striped. A fine selection from the French Gold Striped. Height $21 / 2$ feet. Refined Howers of rich, velvety brown and striped with gold. The straight, strong stems make this sort an ideal cut flower. Illustrated.

$$
\text { 1, oz. \$2.50 1, oz. } \$ 1.50 \text { Pkt. 50c. }
$$

Robert Beist. Dwarf double French type about 1 foot high, described by the originator as a purplish maroon which is new in Marigolds. Ot. $\$ 3.00 \quad 1_{4} \mathrm{oz} . \$ 1.00 \quad$ Pkt. 25c.

Guinea Gold. Very distinct type of Marigold, of graceful, pyramidal habit, 2 to $21 / 2$ feet high and producing 30 to 40 semidouble flowers of a brilliant shade of orange flushed with gold.

Pkt. 50c.

Trivett's Fiery Cross. New! Bright golden yellow with large, dark brown blotch single flowers. Height 9 inches. Splendid for beds and edging. Similar in habit to the popular. Legion of Honor. Oz. \$3.00 $1+$ oz. $\$ 1.00$ Pkt. 25c.

\section{MYOSOTIS (New Forget-me-not}

Trivett's Everblooming. A new type. The Howers are borne on long, stiff stems of exquisite sky blue with white center eys. The principal merit of this sort is that it blooms early and late and may be in bloom at any time of the year. A true peren nial, and like all other Forget-me-nots does exceptionally well in half shady places on the banks of pools, streams, etc.

$$
5 \text { pkts. } \$ 1.00 \quad \text { Pkt. 25c. }
$$

\section{NIEREMBERGIA CALYCINA}

\section{Annual. For hanging baskets, rockeries. I foot.}

Pretty white flowers shaded and veined with lavender. An exceedingly graceful plant for hanging baskets, window boxes, vases, etc. $\quad 1 / 40 \% \$ 1.75 \quad 1 / 0 \% \$ 1.00 \quad$ Pkt. 35c.

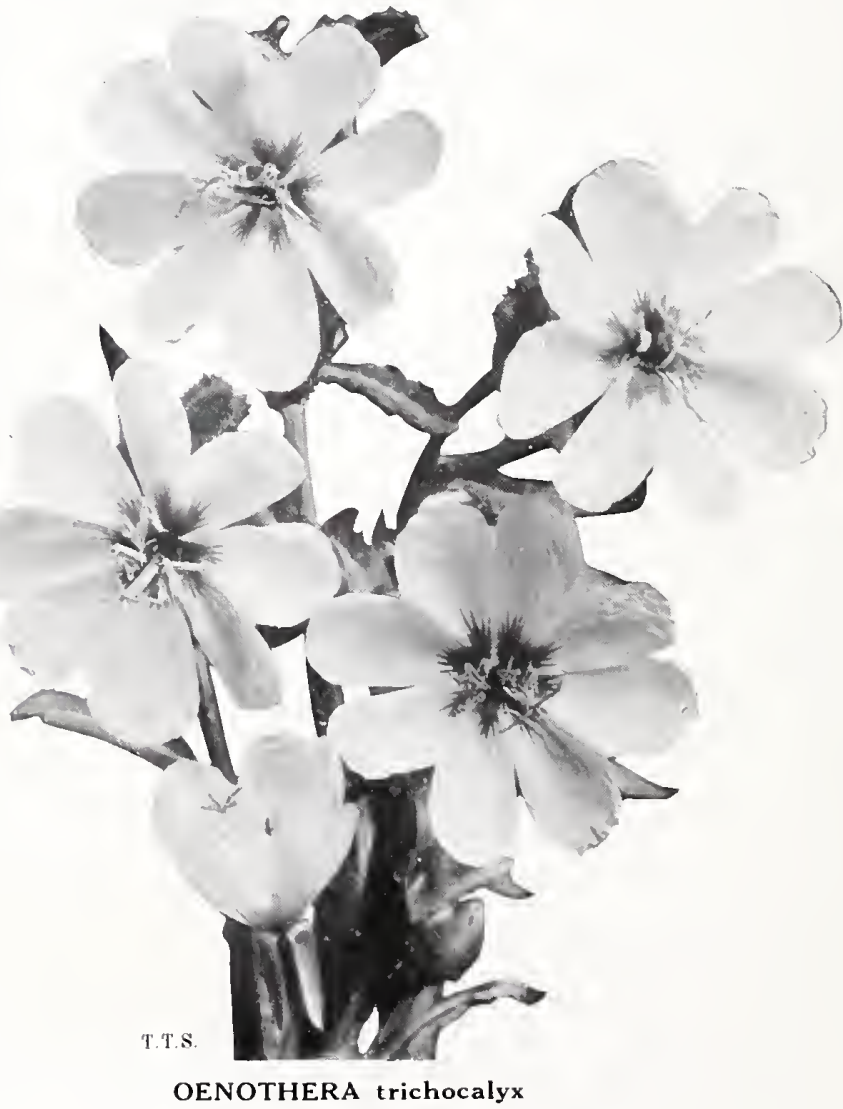


PANSY TREATED

Trivett's New Giants. Introduced by us in 1929, including Roggli's Swiss Giants, English Exhibition Fancy, etc. A mixture prepared especially by ourselves of the finest Pansies procurable.

$$
5 \text { pkts. } \$ 3.50 \quad \text { Pkt. } 75 \mathrm{c} \text {. }
$$

Thuner Sea. (Ullswater). A giant in size. Intense marine blue. The richest and most brilliant blue self. Ideal as a ground cover in beds of yellow Tulips. Pkt. 50c. Steele's Golden Gate. Gigantic golden yellow with dark center. Perhaps the largest and finest vellow Pansy obtainable. $1 / 4 \mathrm{Oz} . \$ 5.00^{1} \mathrm{Ooz} . \$ 2.75 \mathrm{Pkt}^{2} 75 \mathrm{c}$. Steele's MIle. Irene. A new henna red; a wonderful Pansy. $1 / 4 \mathrm{Oz} . \$ 5.00$ ' $5 \mathrm{oz} . \$ 2.75$ Pkt. $75 \mathrm{c}$.

Grand Duke Michel. Without doube the finest and largest all white Pansy procurable. (Steele's.) $1 / 4$ oz. $\$ 3.50$ ' oz. $\$ 2.00$ Pkt. $50 \mathrm{c}$. Mastodon Adonis. Light blue, baby blue and lavender shades. Extra choice large blooms. $1 / 4 \mathrm{oz} . \$ 3.50$ 1/s oz. $\$ 2.00$ Pkt. $50 \mathrm{c}$. Swiss Alp Glow. A separate color selected from the very popular Saciss Giants. The color is rich velvety garnet red or dark scarlet, alnost everblooming and extra large flowers.

$$
5 \text { pkts. } \$ 2.00 \text { Pkt. } 50 \mathrm{c} \text {. }
$$

Mrs. Pierre S. du Pont. An entirely new shade, rich golden apricot flushed with salmon, large flowers on good long stems and almost everblooming. Will provide a gorgeous display in mass beds and especially in contrast to our Thuner Sea or a purple Pansy. Also a splendid ground cover for purple or blue Tulips in Spring beds. 5 pkts. $\$ 3.50$ Pkt. $75 \mathrm{c}$.

Ullswater. See Thuner Sea.

Bowle's Black. Baby Pansy. Very small, about the size of one's $\mathbf{B}$ thumbnail; true jet black low eye. Comes true from seed. Rave, and the seed is scarce.

Pkt. 50c.

\section{PARNASSIA palustris (Grass of Parnassus)}

Elegant, dwarf plant for damp R positions on the rockery or for nial with masses of pure white flowers. Height 6 inches. Pkt. 50c.

\section{PHACELIA tanacetifolia}

Annual. For display and cutting. $11 / 2$ feet.

Large, compact heads of pale mauve flowers, valuable for bees. $\mathrm{Oz} . \$ 1.50$ 1/4 oz. $50 \mathrm{c}$. Pkt. $15 \mathrm{c}$.
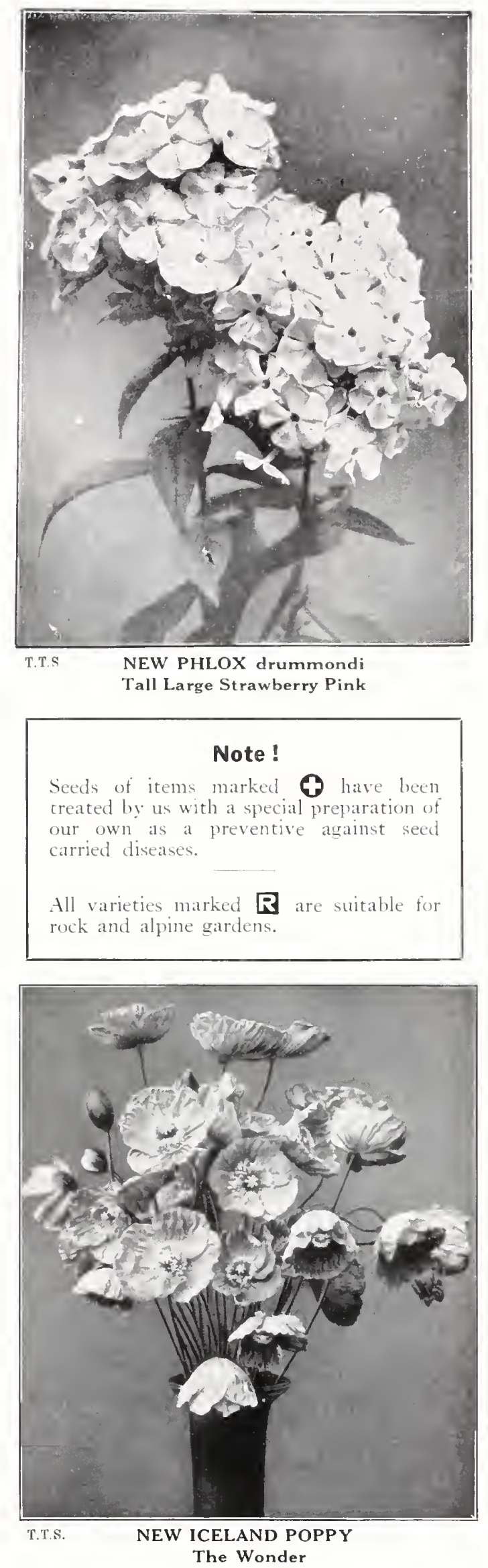

\section{PHLOX drummondi}

Innual. For cutting and display.

TRIVETT'S TALL

Tall Large Strawberry Pink. Fine bright color with a distinct white center.

Oz. $\$ 3.75$ 1 $\$$ oz. $\$ 1.25$ Pkt. 30c.

Tall Large Violet Blue. With white eve in center of each floret. Oz. $\$ 3.75$ 1, oz. $\$ 1.25$ Pkt. 30c.

\section{TRIVETT'S DWARF}

Dwarf Light Red. Attractive shade of vermilion or brick red.

Oz. $\$ 6.00 \quad 1$ 1 0z. $\$ 1.75$ Pkt. 50c.

Dwarf Crimson. Rich deep

crimson with attractive white eve.

07. $\$ 6.00 \div, 02 . \$ 1.75$ Pkt. $50 \mathrm{c}$.

$$
\text { For other rolors of ahow } 7 \text { thlox }
$$

\section{HORTENSIA-FLOW. PHLOX}

A splendid type of the annual Phlox drummondi, semi-dwart, about 9 inches high, producing very large and densely flowered umbels. Magnificent for ledding, edging, etc.

Hortensia Delicate Pink.

lovely shade with rosy red eye.

Hortensia Purple. White eye.

Hortensia Salmon Rose. With bright carmine eye in center.

Hortensia Scarlet. Brilliant dazzling scarlet, very lright.

Hortensia White. Fine pure white. Anr of abore Hortensia carieties. $\mathrm{Oz} . \$ 5.00 \quad 1 / 40 z . \$ 1.50 \quad$ Pkt. $35 \mathrm{c}$.

\section{STAR PHLOX Hgt. $1 \mathrm{ft}$.}

Star shaped or fantastically fringed; in many shades and colors.

Finest Mixed.

Oz. $\$ 3.0011_{4}$ oz. $\$ 1.25$ Pkt. $30 \mathrm{c}$.

\section{POLYGONUM}

\section{tnnual. Fordisplay and cutting. 3ft.}

Ruby Gem. An exceedingly. pleasing form of branching Persicaria, bearing numerous spikes of rich ruby flowers. Pkt.50c.

\section{POMEGRANATE OdD christmas PLANT}

Greenhouse omamental plant. The first flowers should be kept nipped off until well on into September when they will begin to take on a general crop for December and lasting for several months later. Makes an unusual and acceptable Christmas or New Year plant.

Oz. $\$ 1.50{ }^{1}+$ oz. 50c. Pkt. $15 \mathrm{c}$.

POPPY (Single Iceland) Perennial. For borders and rockeries The Wonder: Flowers as big as "Tea Cups" in about 15 colors. This is the most sensational break in Giant Iceland Poppies. Award of Merit, R. H. S

$$
5 \text { pkts. } \$ 3.50 \text { Pkt. } 75 \mathrm{c} \text {. }
$$




\section{PETUNIAS}

"Ile supply originators' seeds only."

\section{SINGLE GIANT PETUNIAS}

Diener's Pink Glory. Inmense blosoms of flaming clear rose pink, with out a trace of purple. Slightly ruffled. 5 pkts. $\$ 1 . \overline{0} 0 \quad$ Pkt. $\$ 1.00$

Trivett's Empress. Extra large, fringed flowers of lilac blue veined with dark blue. 5 plits. $\$ 4.50 \quad$ Pkt. $\$ 1.00$

Trivett's Floretta. Large blossoms, nicely ruffled edges. The color is clear steel blue veined with dark blue. Ilighly recommended.

$$
5 \text { pkts. } \$ 7.00 \quad \text { Pkt. } \$ 1.50
$$

Trivett's Theodosia. Mlagnificent large frilled and ruffled flowers of immense size. Pure rose pink with golden throat. Very choice.

$$
5 \text { pkts. } \$ 9.00 \quad \text { Pkt. } \$ 2.00
$$

King Alphonso. Large, boldly waved and fringed flowers of very dark crimson, deepening to black in the throat. 5 pkts. $\$ 1.50 \quad$ Pkt. $\$ 1.00$

\section{DOUBLE GIANT} PETUNIAS

Produces about $35 \%$ double.

Trivett's Brilliant Rose. Lovely shade of bright rose. 5 pkts. $\$ 4.50 \quad$ Pkt. $\$ 1.00$

Lady of the Lake. Immense double fringed, pure white. 5 pkts. $\$ 4.50 \quad$ Pkt. $\$ 1.00$

Trivett's Lilac Queen. New silvery lilac, large double blossoms. Plain edged.

5 pkts. $\$ 4.50 \quad$ Pkt. $\$ 1.00$

Trivett's Peony Flowered. These are the real monsters; immense ruffled and fringed double flowers, measuring 4 to 5 inches across and in a wide range of beautiful and strange colors. In mixture only. $B e$ sure to watch for the latest and weakest seedlings, these may be the best.

5 pkts. $\$ 10.00 \quad$ Pkt. $\$ 2.50$

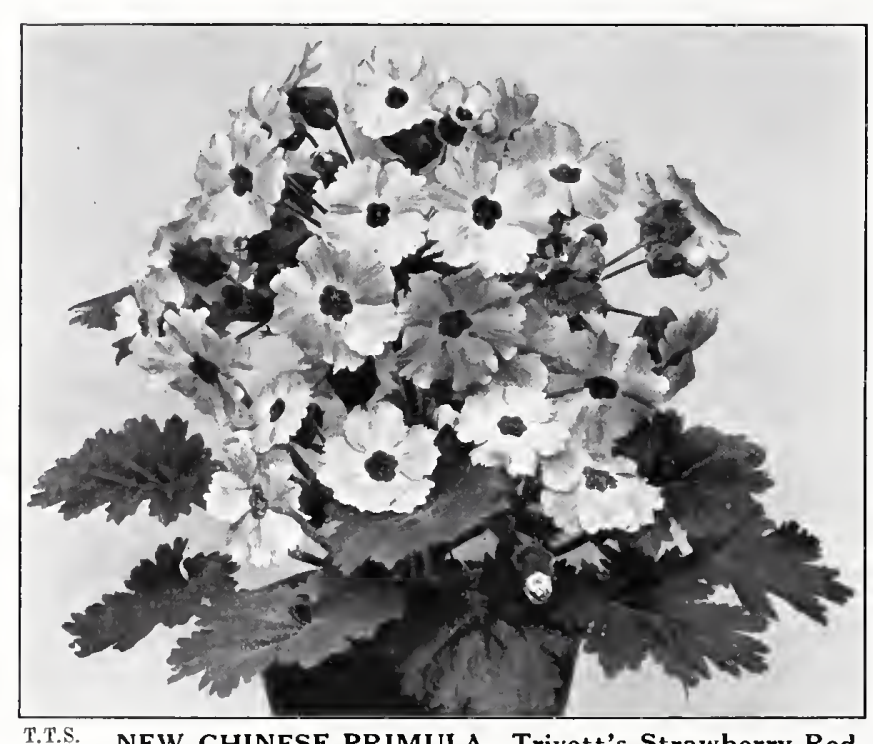

NEW CHINESE PRIMULA-Trivett's Strawberry Red

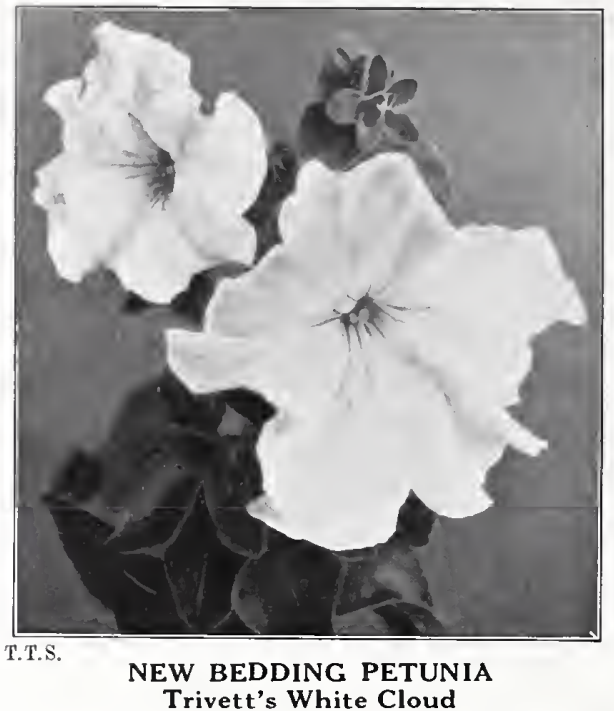

For all other Petunias and Primulas, see our General Catalogue.

"We supply originators' seeds only."

\section{CHINESE PRIMULAS}

Trivett's Strawberry Red. Grown for us by an English Primula specialist. Greenhouse saved seed. The color is dark strawberry red, washed over with a coppery red shade.

5 pkts. $\$ 6.50 \quad$ Pkt. $\$ 1.50$

Trivett's Orange King. Beautiful rich, orange color toned with a wash of salmon; magnificent.

5 pkts. $\$ 6.50 \quad$ Pkt. $\$ 1.50$

Sutton's The Duchess. (Sulton's Seed.) Large white flowers with a zone of bright carmine surrounding a clear yellow eye.

5 pkts. $\$ 6.50 \quad$ Pkt. $\$ 1.50$

Sutton's Reading Blue. (Sutton's Seed.) One of the best blue Primulas; fine, upright trusses.

5 pkts. $\$ 6.50 \quad$ Pkt. $\$ 1.50$

Sutton's Reading Ruby. (Sutton's Seed.) Rich, ruby color, invaluable for dinner table decoration. Lovely shade under artificial light.

5 pkts. $\$ 6.50$ Pkt. $\$ 1.50$

Trivett's Double Carnation Flowered. In this new Primula we have a splendid novelty. The Carnation-like blooms are twice the size of the old type, attaining a diameter of about 2 inches (see illustration.) This wonderful new double Chinese Primrose reproduces itself almost entirely true from seed and comes in a fine range of colors. Mixture only. 5 pkts. $\$ 6.50$ Pkt. $\$ 1.50$

\section{PRIMULA OBCONICA}

Trivett's Triumph Rose. Brilliant dark rose, immense trusses of extra large blooms on robust, compact plants. Highly recommended.

5 pkts. $\$ 7.50 \quad$ Pkt. $\$ 1.75$

Trivett's Triumph Red. Similar to above, but of rich, glowing red color.

5 pkts. $\$ 7.50 \quad$ Pkt. $\$ 1.75$

\section{STAR PRIMULAS}

\section{BEDDING PETUNIAS}

Trivett's Blue Gem. Introduced by us in 1929. Splendid habit, the flowers are clear midblue, a real blue Petunia. Medium size flowers. Ideal for bedding. Height 18 inches.

$$
5 \text { pkts. } \$ 3.50 \quad \text { Plkt. 75c. }
$$

Trivett's Crimson Bedder. Single medium sized flowers of brilliant, rich red. Try this edged with dwarf yellow Annual Phlox.

$$
5 \text { pkts. } \$ 3.50 \quad \text { Pkt. } 75 \mathrm{c} \text {. }
$$

Trivett's White Cloud. Large flowered, about 3 inches across, but on dwarf, bushy plants, only 12 inches high, producing a veritable cloud of snow white. Useful for any purpose.

$$
5 \text { pkts. } \$ 2.25 \quad \text { Pkt. } 50 \mathrm{c} \text {. }
$$

Trivett's Double Rosy Gem. Brilliant rose for bedding, etc. About 12 inches high. ... 5 pkts. $\$ 2.25$ Pkt. $50 \mathrm{c}$

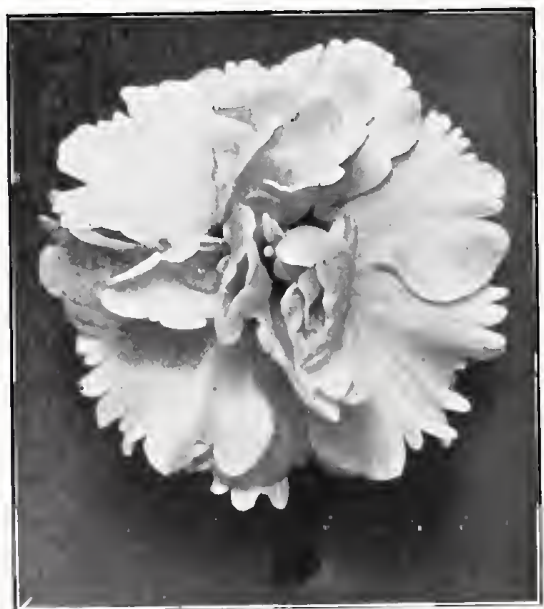

T.T.S. NEW CHINESE PRIMULA Trivett's Double Carnation Flowered
Trivett's Ruby Star. Beautiful, dark, rich ruby color.

5 pkts. $\$ 6.50 \quad$ Pkt. $\$ 1.50$

Sutton's Dark Blue Star. (Sutton's Seed.) Attractive violet blue with yellow eye, $\quad . .5$ pkts. $\$ 6.50 \quad$ Pkt. $\$ 1.50$

\section{PRIMULA MALACOIDES}

Trivett's New Blue. Splendid, largeflowered, pure blue sort.

5 pkts. $\$ 4.50 \quad$ Pkt. $\$ 1.00$

Trivett's New Crimson. Another new color we have added this year Rich, bright crimson. 5 pkts. $\$ 4.50$ Pkt. $\$ 1.00$ Sutton's Eclipse. (Sutton's Seed.) Plants are dwarf in habit, producing very large, individual flowers of deep lavender pink. 5 pkts. $\$ 6.50 \quad$ Pkt. $\$ 1.50$ Sutton's Achievement. (Sutton's Seed.) Another choice sort which we procure direct from the originator. Nicely rounded, large flowers of clear rose pink. 5 pkts. $\$ 4.50 \quad$ Pkt. $\$ 1.00$ 


\section{PYRETHRUM}

\section{Perennial. For cutting and borders.}

Trivett's Ruby Red. Rich, deep red single flowers. ... ... Pkt. 50c

Trivett's Scarlet. The brightest color. Flowers extra large, single.

\section{RANUNCULUS}

Giant Palestine Mixed.

of Merit, R. H. S. Without question the largest and finest type yet introduced. Wonderful range of rich colors. Long, strong stems for cutting. Pkt. $50 \mathrm{c}$

\section{RUDBECKIA}

(Annual)

\section{Golden Sunset. Attractive annual}

of great merit, compact plants covered with golden yellow flower marked with chestnut. Height $1 \frac{1}{2}$ feet. Autumn flowering; splendid forcutting. Pkt 50

SALVIA SPLENDENS OR Amual. For bedding. Height 18 inches.

Trivett's Parma Violet. Producing long flower spikes, similar in shade to the well known Parma Violet. Pkt. 50c.

Trivett's Rose Pearl. Splendid bedder or border plant. The flowers are bright, true rose shaded with salmon.

Trivett's Salmo Pkt. $50 \mathrm{c}$. Dwarf compact plants above 15 inches high, covered with flower spikes of rich salmon-pink. Splendid for bedding, borders, pots, etc. Illustrated. Pkt. 50.

Trivett's White Pearl. Producing abundance of snowy white flowers. A charming companion to our Rose Pearl.

\section{OTHER SALVIAS}

Salvia of the Vatican Gardens. A handsome selected variety of "Salvia sclarea," coming originally from the Vatican gardens. It forms a handsome plant 5 feet high with broad foliage and graceful heads of lavender and white flowers with silvery pink leaf bracts. Hardy biennial. Pkt. $\$ 1.00$

Trivett's Improved Farinacea. A much improved form of the popular Salvia farinacea, being of more compact growth and producing flowers of a deeper and better blue.

\section{SALPIGLOSSIS TREATED $\{$ SEEDS}

\section{Sutton's Chelsea Hybrids.}

ton's Seed. The wonderful strain, including all the brightest colored and largest flowered varieties which won the Gold Medal at the Chelsea Show in England.

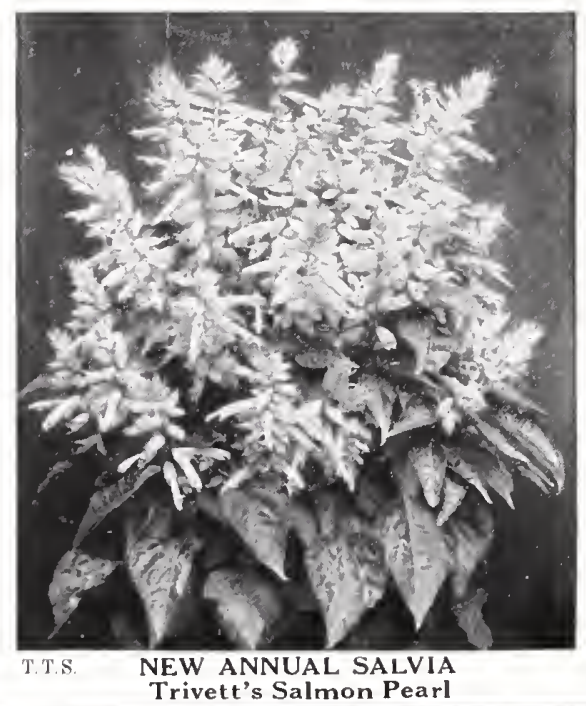

SAXIFRAGA

Peremmal. For rockeries, walls, etc.

Bathoniensis. Very handsome variB ety, bright rosy scarlet flowers, mos$\boldsymbol{B}$ sy type. Height 12 inches. Pkt. 50c. Lantoscana Superba. One of the $\mathbf{R}$ finest of the encrusted varieties; lovely white flowers in large, arching panicles. Height 12 inches. Should have sunny position in the rockery. Pkt. 50c.

Longifolia. (The Queen of Saxifra$\mathbf{R}$ ges). Handsome rosettes of long narSow "frosted" foliage; erect branching panicles of white flowers. Pkt. 50c.

Mossy Sorts Mixed. Includes all $\boldsymbol{B}$ the finest varieties of this class: P'kt. 50c

Encrusted Sorts Mixed. Including many choice varieties for rocks, walls, etc.

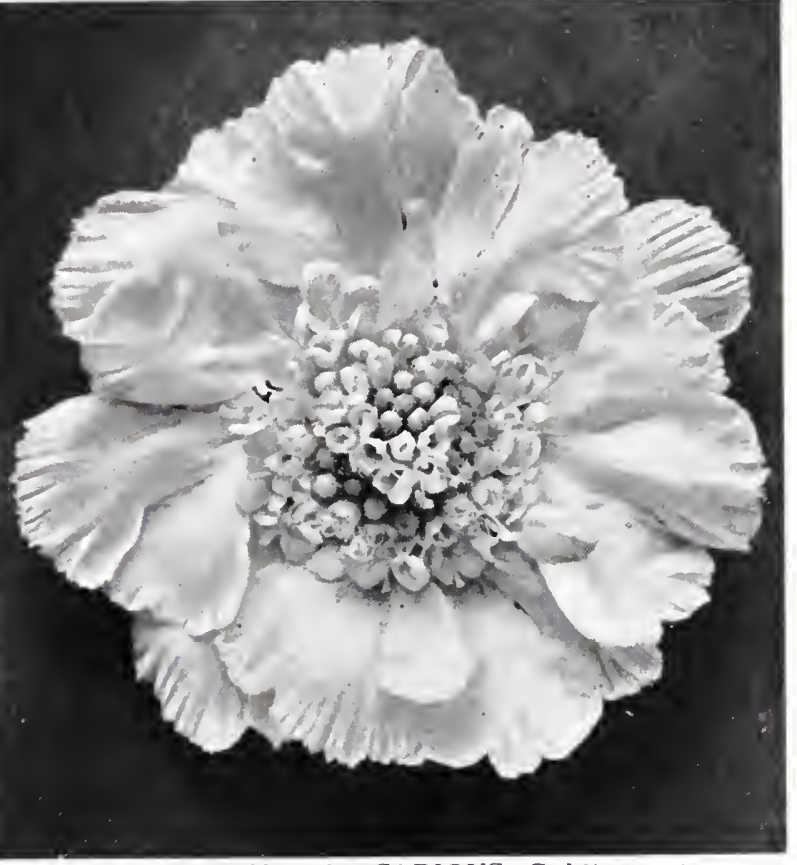

SCABIOUS ANNUAL

Annual. For cuting. 21/2 feet. Giant Shasta. Bearing on long stems, large flowers, snowy white, often $31 / 2$ inches across. Giant Peach Blossom. A charming shade of Peach blossom pink. Splendid large blossoms. ... ... Pkt. $35 \mathrm{c}$.

\section{TRIVETT'S BABY SCABIOUS}

Mixed. Charming miniature annual Scabious growing about 8 inches in height. The bushy little plants are almost 12 inches wide and covered with extra double flowers. Valuable for edging, bedding, Oz. $\$ 3.001 / 4 \mathrm{oz} . \$ 1.00 \mathrm{Pkt} .35 \mathrm{c}$.

\section{PERENNIAL SORTS}

\section{House's New Giants.}

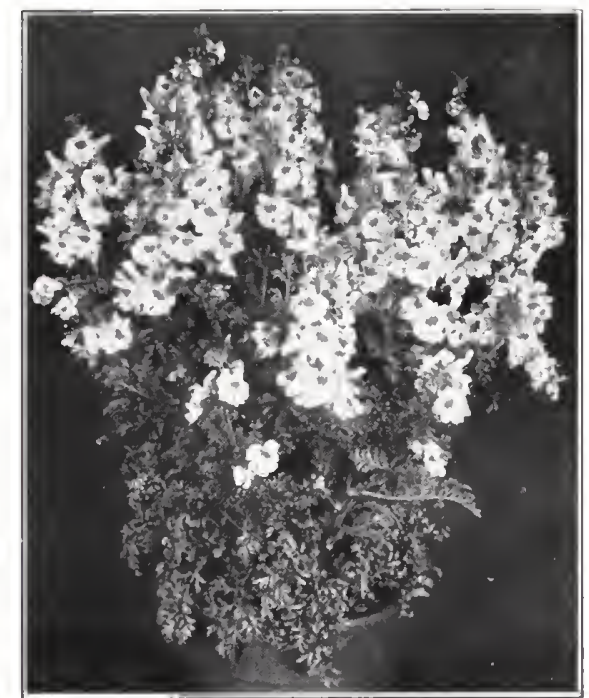

beautiful strain of the Caucas. ica type. Very large flowers. 'The colors range from light azure, lavender to deep blue and white. ... Pkt. 75c. Columbaria, Rosy Mauve. Tew! Handsome flowers, 2 to $21 / 2$ inches across on long, wiry stems, splendid for cutting; decorative, laciniated foliage. $\ldots$.. $\quad \ldots \quad \ldots$... Pkt. 50c. Goldingensis. New! A very fine strain of $S$. caucasica, large flowers of fine, deep lavender color. Long stems.

\section{SCHIZANTHUS}

Trivett's New Giants. We have been fortunate in securing this grand strain for our customers. Immense flowers in many colors on plants of fine habit, which can be grown on in to wonderful large specimens if desired by repotting. 5 pkts. $\$ 4.50$ Pkt. $\$ 1.00$ 


\section{SENECIO clivorum}

Feremial. For banks of ponds, etc. strong growing, hardy perennial with rich orange yellow flowers and bold foliage, well adapted for the side of ponds, streams and damp places. Height 4 to 5 feet.

Oz. \$3.00 1/4 oz. \$1.00 Pkt. 250

\section{SHASTA DAISY}

Peremial. For cutting and borders. FOR MAY FLOWERING

Trivett's May Wonder.

plants begin flowering in May just at a time when cut Howers are scarce in the garden. Our May Wonder produces double and semi-double white Howers on fine, stout stems. Very valuable for cutting and perennial borders. Height about $21 / 2$ feet. 5 pkts. $\$ 2.25$ Pkt. 50c.

FOR JUNE FLOWERING Trivett's June Cream.

Charming cream color, just a little change from the decided Paperwhite of most Shasta Daisies. Large flowered, good stems for cutting. About 3 feet high. 5 pkts. $\$ 1.00 \quad$ Pkt. $25 \mathrm{c}$. For Fune Flowering, see also Alaska and

\section{FOR JULY AND LATER} Mrs. C. Lowthian Bell. This magnificent white Mar guerite is one of the largest flow ered. The flowers are purest white, about 5 inches across on strong, stout stems. This sort will continue to bloom all Sum mer and into Autumn. Height about 3 feet.

$$
5 \text { pkts. } \$ 1.50 \text { Pkt. 35c. }
$$

For Fuly Flowering, see also King Edward

\section{SOLANUM} CHRISTMAS CHERRY TREATED CLEVELAND CHERRY

Ornamental greenhouse pot plant.

Trivett's Red. A Cleveland Cherry of great improvement over the regular red Cleveland Cherry. The plants are more compact and bushy and the scarlet red berries are produced in greater abundance.

$$
\text { pkts. } \$ 2.25
$$

$$
\text { Pkt. 50c. }
$$

Yellow Cleveland Cherry. This is the regular type with yellow berries. Makes a good contrast against the red. 5 pkts. $\$ 2.25$ Pkt. 50c.

Bird's Eye. Unique and attractive little pot plant. Forms bushy little plants which become covered with acorn-shaped fruit. A plant at one and the same time will carry flowers and berries and the latter will be at differcnt stages, some being white, yellow, blue, purple and red as they ripen. 5 pkts. $\$ 2.25$ Pkt. 50c.

Solanum, Jerusalem Cherry. Sce our General Catalogue

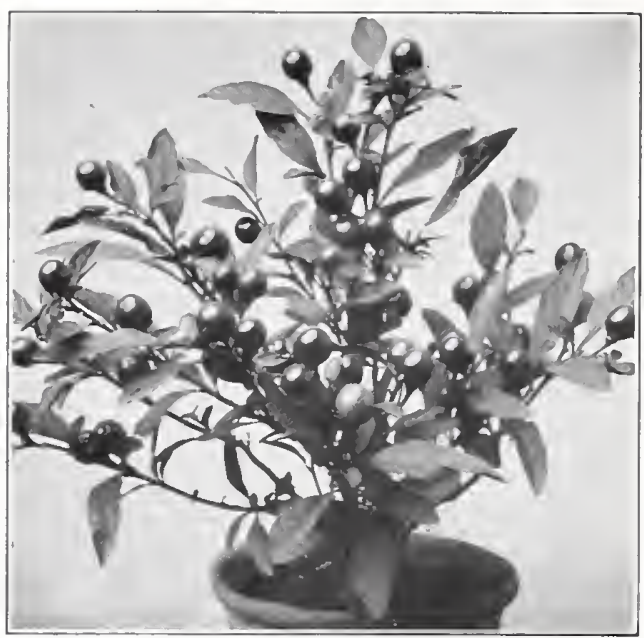

CLEVELAND CHERRY (SCLANUM)-Trivett's Red

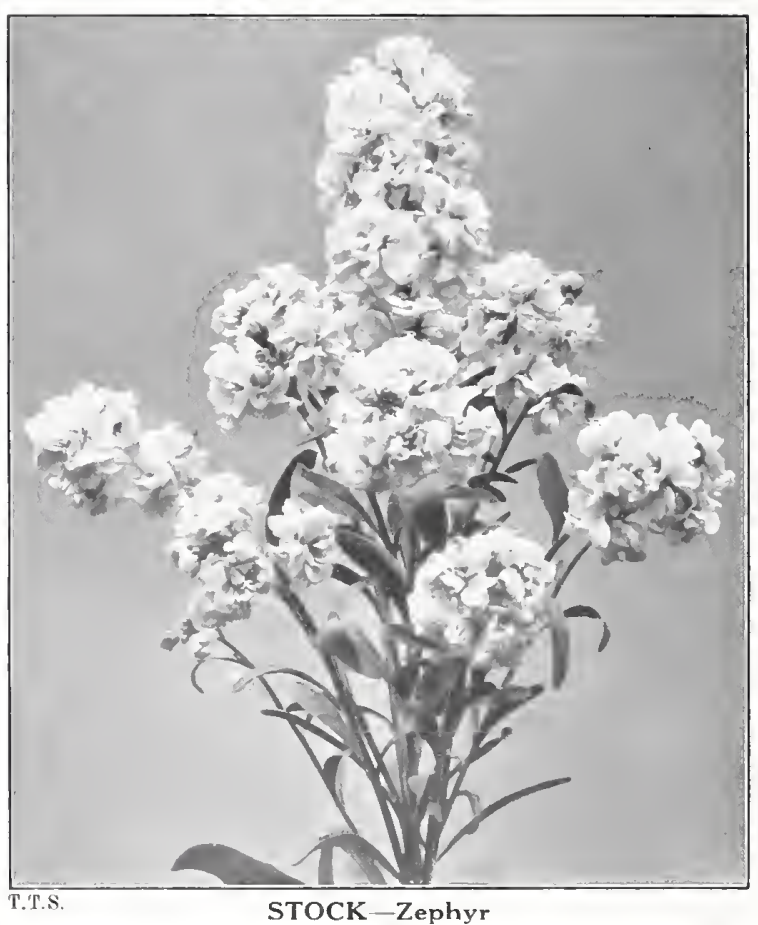

STOCKS

TREATED $\bigcirc$ SEEDS

TRIVETT'S GREENHOUSE TYPE

The best of all for forcing and Winter flowering under glass. The plants are extra early flowering requiring only about 12 weeks from the time the seedlings are benched or potted. Strong, healthy growth, about $21 / 2$ feet in height and of branching habit, producing innumerable large flower spikes measuring from 12 to 16 inches long, covered with extra large, double individual blooms. The percentage of "doubles" will be found, as a rule, excepionally high!

Quick, early flowering crop.

Trivett's $\left\{\begin{array}{l}\text { Old Rose } \\ \text { Yellow } \\ \text { Lavender } \\ \text { Purple } \\ \text { Deep Pink } \\ \text { Light Pink } \\ \text { Blood Red } \\ \text { White }\end{array}\right.$

For quick growing and early flowering, we strongly recommend the above sorts.

Frice, each of above colors

$1 / 1$ Oz. $\$ 3.00 \quad 1 / 8$ oz. $\$ 1.75$

\section{STOCK}

\section{TREATED SEEDS}

Zephyr. This beautiful stock may be classed with the Giant Beauty types. In color it is the most delicate lavender blue, producing a main middle stem and numerous side shoots for cutting. Plit. 50c.

\section{STREPTOSOLEN}

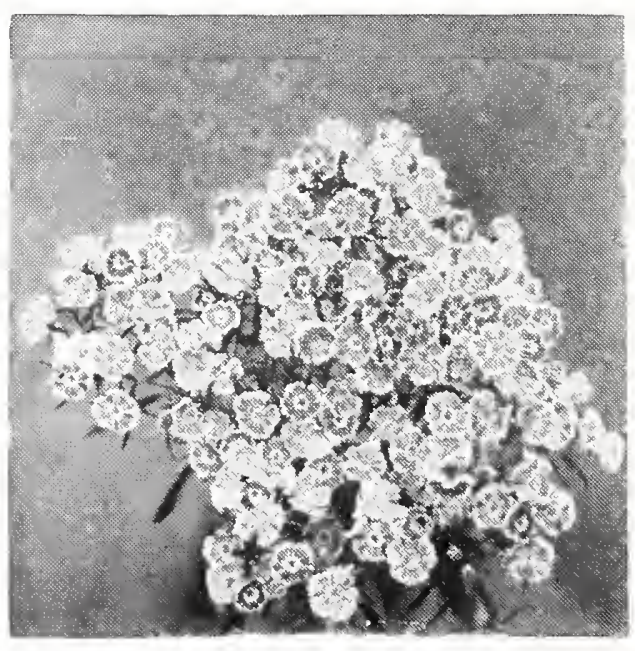

T.T.S. SWEET WIVELSFIELD
Greenhouse plant. Height 3 to 4 feet. Jamesoni. Lovely plant of elegant habit, bearing corymbs of showy brilliant orange yellow flowers. Similar to Lantana. Can be trained as a climbing plant.

Pkt. $\$ 1.50$

\section{SWEET WIVELSFIELD}

Annual. For bedding, cutting, etc. A new annual flowering plant obtained by crossing Dianthus allwoodi and Sweet-william. It is distinct in habit and freedom of growth. Wonderful colors. The flowers are produced in trusses or bunches like a large, loose head of Sweet-william, but the individual florets resemble small single Carnations or Pinks. (In mixture only.)

5 pkts. $\$ 2.25$

Pkt. 50c. 


\section{GIANT SWEET PEAS}

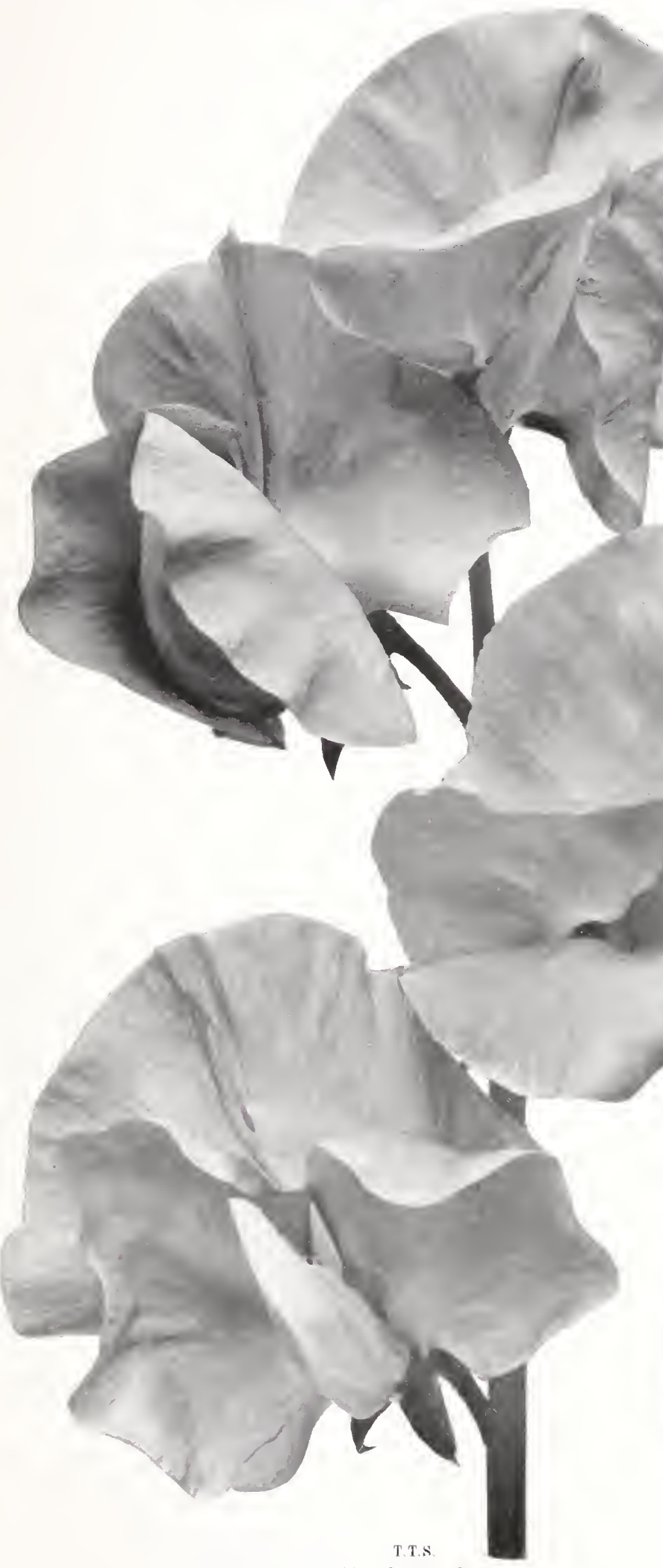

NEW SWEET PEA-Good Cheer (See next page)
For Keen Exhibitors and Those Who Demand the Best

TREATED SEEDS

All Sweet Pea seeds sold by us are treated with a special preparation of our own as a preventive against seed-carried diseases. Every packet bears our Ked Seal "Treated Seeds"

$$
\text { T) }
$$

In the following pages we offer the best of the novelties for 1931 and a selected list of the 1930 novelties. T)

For the general list of standard varieties and those of recent introduction, please refer to our special Sweet Pea Catalogue or our General Seed Catalogue.

\section{Prominent Prize Winners}

( hur Siweet Peas, under the intelligent and scientific culture given them by our customers have become prominent prize wimners at the Hower shows throughout the country.

\section{TRIVETT'S NOVELTY MIXED 1931}

This is a very special mixture including such splendid novelties as Aralanche, Beatall, Big Ben, Blue Bell, Leviathan, I eslie Rundle, Mrs. A. Searles, Purple Perfection, Ruffed Rose, Ruddigore, Satin Mauve, 'The Admiral, Gold Crest, Heavenly Blue, etc. The finest mixture procurable.
Lb. $\$ 9.00$
$1 / 4$ Ib. $\$ 3.00$
Oz. $\$ 1.00$
Pkt. 30c.

\section{Trivett's Tested Seeds \\ Seed and Bulb Specialists}

59 and 61 PARK PLACE, NEW YORK 


\title{
1931 NOVELTIES ENGLISH-GROWN SWEET PEAS \\ TREATED SEEDS
}

\author{
RAISER'S DESCRIPTIONS IN ALL INSTANCES
}

\begin{abstract}
Amethyst (Dobbie). Bright, clear amethyst blue. Everyone should grow this superb novelty. It is a great advance over its predecessors in this color class. A vigorous grower, the flowers are exceptionally large and wavy, and are freely produced on long stems of great strength. Pkt. (12 seeds) 50c.
\end{abstract}

Blue Ribbon (Cullen). We have not yet seen a variety so strikingly rich in gentian blue coloring as Blue Ribbon. The standard of the flowers is very large, well waved and of deep blue color, shaded purple. The wings are brightest gentian blue; very strong grower.

Pkt. (12 seeds) 50c.

Captain Blood (I. and H.) Grown at the National and Scottish Sweet Pea Trials as S. 29. This outstanding novelty introduces a new color hitherto unseen in Sweet Peas. Its name suggests red; it is more than that - it is a brilliant blood scarlet veneered with a delightful shade of copper. Flowers of magnificent size and substance on good stems that will please the most exacting exhibitor. Pkt. (12 seeds) 50c.

Celebrity (Morse). We offer Celebrity as the most vigorous growing orange colored Sweet Pea. The flowers are unusually large and the stems long and strong. Exhibitors who shade their flowers will find Celebrity a marvelous dark orange color. Pkt. (30 seeds) $50 \mathrm{c}$.

Conqueror (Morse). Large, glowing cherry cerise, the color is quite distinct from any of the scarlet red sorts. The vines are vigorous and the flowers borne on fine, strong stems. The color will even improve under bright sunshine and under artificial light is very attractive. Pkt. (30 seeds) 50c.

Damask Rose (Cullen). Award of Merit, N. S. I'. S. trials, 1930. The shade of the old-fashioned Damask Rose, but brightened by a lustrous carmine sheen. The large, well frilled flowers are freely produced on long, stout stems, generally four to a stem. Grand exhibition sort. Pkt. (12 seeds) 50c.
Dream (Stevenson). Beautiful salmon buff; the standard is deeper in color than the wings; growth is vigorous and the flowers large and beautifully formed. Exceedingly dainty variety.

Pkt. (12 seeds) 50c.

Eosine (Morse). A fine novelty of the long-stemmed type. According to our chart, the color is a shade of Eosine pink with a wash of salmon. Exceedingly large blooms on very stout stems. We predict that Eosine will be a great favorite with exhibitors. Pkt. (30 seeds) 50c.

Fantasy (Unwin). "Out of the usual" and will not fail to attract attention. Rich, chocolate maroon splashed over a cream ground; a pleasing color-blending not previously met with in Sweet Peas. Pkt. (15 seeds) 50c.

Fire (Burpee). Flaming red illuminated by a glow of deep cerise. Fire has a tendency to produce five-flowered sprays. The vines are vigorous, carrying an abundance of long-stemmed, duplex blooms. Certificate of Merit, Scottish Sweet Pea Society. Pkt. (20 seeds) 50c.

Good Cheer (Morse). Awarded the Silver Medal at the Scottish Sweet Pea Society's trials. The flowers are huge when well grown, and are a lovely shade of deep Begonia rose. We consider Good Cheer a great flower for the exhibitor and for general garden culture. (Illustrated on page 21.)

$$
\text { Pkt. (30 seeds) 50c. }
$$

Innocence (Unwin). The finest white Sweet Pea yet introduced, and we believe it will very quickly become the most popular in its class. It is dark seeded, a most vigorous grower, and nothing is lacking in size of bloom, length of stem, form and substance of petal. Pkt. (15 seeds) 50c.
Joan Curtis (Bolton). First Class Certificate, N. S. P. S. A pink Pea in which salmon is toned with flesh; its flowers are deeply waved and attain exhibition size and quality. A most important characteristic being that it is entirely sunproof. Pkt. (12 seeds) 50c.

Laddie (I. and H.) Grown at the National Sweet Pea trials as S. 218. We have every confidence that Laddie will become one of the most popular varieties in commerce. Beautiful apricot cream pink that is distinct from any existing variety. Identical in color to the popular Camation, Laddie. The Howers are nicely ruffied, nearly every blossom being duplex, of large size and on fine stems. Pkt. (12 seeds) 50c.

Loch Lomond (Bolton). First Class Certificate, N. S. P. S. The richest of the mahogany shades brightened by a lustrous sheen, as rich and distinctive as the color of the finest panels of old mahogany wood. No magenta or purple mars its beauty. The flowers are large, finely modeled and well placed on strong rigid stems. On the exhibition table it will be outstanding and in the garden will command attention.

Pkt. (12 seeds) 50c.

Memories (Dobbie). A charming name for a very delightful and fascinating Pea. The color tone is bright yet pale rose cerise. The flowers are large and beautifully waved and fluted and almost every stem carries four blooms with sometimes five. A truly grand sort. Pkt. (12 seeds) 50c.

Orange Flame (Burpee). The deepest of all orange Sweet Peas. Like the color of a fully ripened tangerine orange. The flowers are well proportioned, large, heavy and substantial.

Pkt. (20 seeds) 50c. 


\section{THE FINEST THE WORLD PRODUCES}

Pink Glow (King). Silver Medal, Dutch N. S. P. S.; Award of Merit, National Sweet Pea trials, 1930. Winner of First Prize, Table Decoration Class, National S. P. Show. A grand pink flushed with bright salmon which gives the flower a glowing appearance.

Sold out.

Ruffled Orchid (Burpee). Lovely lavender rose, typical of certain Cattleya Orchids. The Howers are well ruffled and frilled and are gracefully arranged on long, strong stems. Rufled Orchid is the fourth of the grand Ruffled family. Honorable. Mention by the Sweet Pea Society of Great Britain. Pkt. (20 seeds) 50c.

Sonny Boy (King). Award of Merit, X. S. P. trials. Award of Merit, Dutch S. P. S. F. C. C. Brussels, 1930. A new color in Sweet Peas and quite distinct. A fine, bold flower of brilliant vermilion red with a velvety sheen of remarkable substance. Freely produced fourflowered stems. Pkt. (12 seeds) $50 \mathrm{c}$.

The Flag Lieutenant (I. and H.) Intense navy blue, the wings are pure violet, while the standard is overlaid with a beautiful indigo blue sheen. A most vigorous grower, producing five bloom sprays of gigantic form that will prove a great acquisition in every exhibition collected and garden.

$$
\text { Pkt. (12 seeds) 50c. }
$$

Tip Top (Hurst). Silver Medal, S. N. S. P. S. trials. The nearest approach to a true blue Sweet Pea that we have seen. Large flowers of good form are produced in abundance and nicely placed on the stems. Grand for the exhibition stand and in the garden. Pkt. (10 seeds) 50c.

Yule Log Glow (King). Imagine the glow of a Yule log and the rich fiery orange red at once impresses one with the warmth of beauty reproduced in this variety. Large, duplex flowers in abundance. Pkt. (12 seeds) 50c.
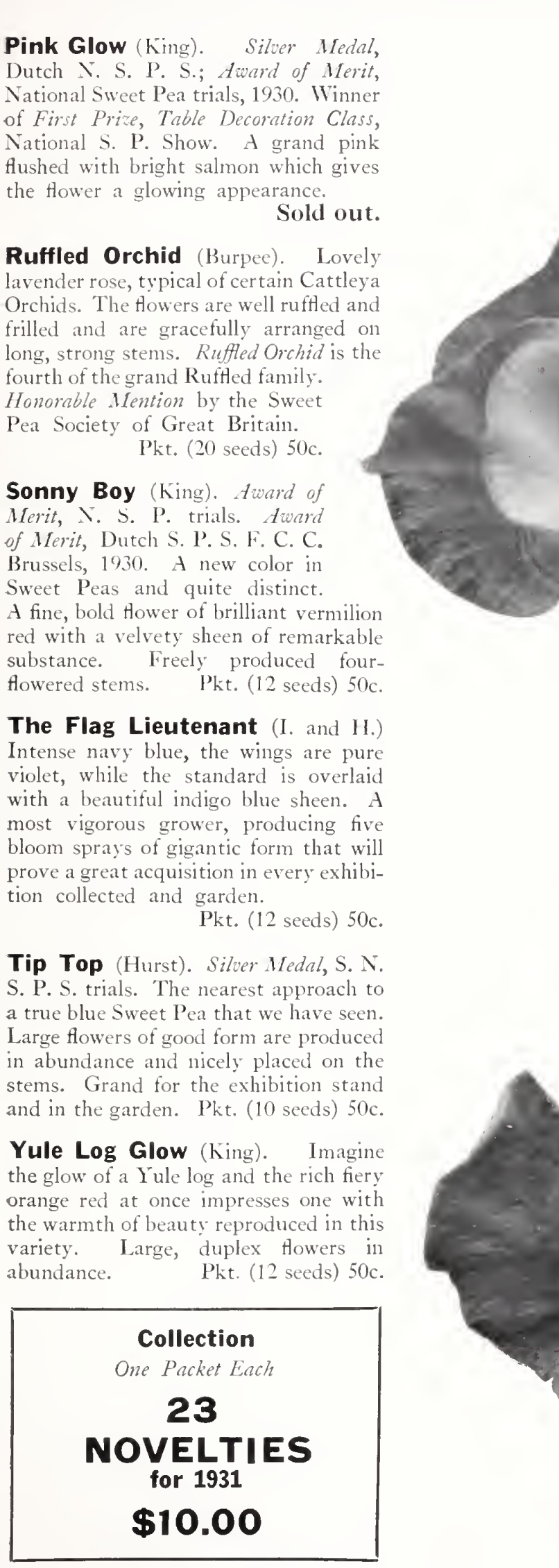

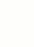

\section{(1)}




\section{GiAnT SWEet PEAS \\ for Keen Exhibitors and Those Who Demand the Best 1930 NOVELTIES \\ TREATED SEEDS}

RAISER'S DESCRIPTIONS (ABRIDGED) IN ALL INSTANCES

All Bright (Morse). Brilliant shade of scarlet cerise suffused with orange; this sort will top the list of Red Sweet Peas, the stems have great length and usually bear four flowers. There is not the slightest trace of burning.

Oz. $\$ 3.00 \quad 1 / 2$ oz. $\$ 1.75$ Pkt. 50c.

Ascot. A truly beautiful variety of the most pleasing, clear pink color. The blooms are of largest size, well formed and intensely frilled. An exhibition sort of the highest class.

Oz. $\$ 1.50 \quad 1 / 2$ oz. $80 \mathrm{c}$ Pkt. 30c.

Beatall (Bolton). Award of Merit, N.S.P.S., 1929. A pink which surpasses all others in richness and brilliancy. Salmon tints merging with rose produce a distinct shade. Massive flowers and beautifully frilled standards are borne on excellent stems. The plants are strong and vigorous. Beatall is a wonderful Pea.

Oz. $\$ 3.00 \quad 1 / 2$ oz. $\$ 1.75 \quad$ Pkt. $50 \mathrm{c}$.

Big Ben (King). Award of Meril, N.S. P.S., 1929. New and distinct color belonging to the fancy section. A wash of crimson scarlet over a cream ground. A rampant grower of huge, duplex flowers on long, stiff stems.

Oz. $\$ 3.00 \quad 1 / 2$ oz. $\$ 1.75 \quad$ Pkt. $50 \mathrm{c}$.

Blue Bell (Bolton). A superb novelty. The true blue of the Scotch Bluebell; of astonishing vigor, producing its immense blossoms in great profusion. Oz. $\$ 2.00 \quad 1 / 2$ oz. $\$ 1.25$ Pkt. 35 c.

Blue Flame (Morse). The largest dark blue Sweet Pea in existence; although deeper than the blue of Mrs. Tom Fones, yet it is not a navy blue, it is a real true deep blue. Four Howers to a stem, delightfully fragrant. A grand exhibitors' Pea.

Oz. $\$ 2.00 \quad 1 / 2$ oz. $\$ 1.25 \quad$ Pkt. 35 c.
Boy Blue. Considered by many as the best bright blue. Beautifully modeled blossoms, nicely placed on strong, stout stems.

Oz. $\$ 1.50 \quad 1 / 2$ oz. $80 \mathrm{c}$ Pkt. $30 \mathrm{c}$.

Cambria (Bolton). Shining rose pink on a white ground, full of life and radiance. The flowers are very large, the stems are long and strong. Grand exhibition sort.

Oz. $\$ 3.00 \quad 1 / 2$ oz. $\$ 1.75 \quad$ Pkt. 50c.

Cherrio (King). Distinct from and better than Tom W'ebster. Lovely clear blue; one of the best in this color class and worthy of a place in every high class collection.

Oz. $\$ 3.00 \quad \frac{1}{2}$ oz. $\$ 1.75$ Pkt. 50c.

Cherry Glow (I. and H.) For the exhibitor Cherry Glow will produce flowers of rare size and strength, beautiful, glistening cherry pink; retains pureness in water and even improves its rich shade under artificial light.

Oz. $\$ 2.001 / 2$ oz. $\$ 1.25$ Pkt. $35 \mathrm{c}$.

Clarion (Dobbie). The wings are of violet tone and the standards violet flushed with rose, four and five flowers on long, strong stems; robust constitution. One of the most popular prize winners in Europe during 1929.

Packets only, Pkt. (50 seeds) 50c.

Flaming June (Carter). Secured First Prize in novelty class, 1930. Reserved for the Gold Medal at the trials of the N. S. P. S. Certificate of Merit, Scottish trials. A flaming scarlet cerise which revels in the strongest sunshine; of giant size, perfectly formed and waved. Splendid for exhibition or the garden.

Oz. $\$ 3.00 \quad 1 / 2$ oz. $\$ 1.75$ Pkt. 50c.

Glen Eagles. V'ery large, frilled flowers of soft lavender blue. A most desirable sort and one of the best in this color class.

Oz. $\$ 1.50 \quad 1 / 2$ oz. $80 \mathrm{c}$ Pkt. $30 \mathrm{c}$.
Golden West (Stark). The rich bronze of a sunset describes the color of this beautiful Pea; large size, grand for exhibition, slight shade will improve the beautiful color for exhibition.

Oz. $\$ 3.00 \quad 1 / 2$ oz. $\$ 1.75 \quad$ Pkt. 50c.

Kia-Ora (Stark). Deep maroon. The color reminds one of a glass of old Port. An exhibition sort of the first class. Packets only, Pkt. (50 seeds) 50c.

Leviathan (Stark). Certificate of Merit, Scottish Trials; Special Silver Medal, Peterboro. A giant Sweet Pea of glowing rich maroon. Even grown in the ordinary way the flowers are of exhibition size. We recommend growing on at least two stems for exhibition. The flowers are both duplex and triplex and are beautifully frilled. Undoubtedly at the head of this color class.

Packets only, Pkt. (50 seeds) 50c.

Lilac Time (Stevenson). Quite distinct, unique shade of lavender lilac and extremely vigorous growth.

Oz. $\$ 2.00 \quad 1 / 2$ oz. $\$ 1.25 \quad$ Pkt. 35c.

Lolly. A lovely salmon pink; immense blooms of very refined form, produced freely on long, strong stems; vigorous vines.

Oz. $\$ 1.50 \quad 1 / 2$ oz. 80 c. Plkt. 30c.

Magnet. Bright cream pink. Lovely, well formed flowers of large size on strong, long stems. Ideal for exhibition or garden.

Oz. $\$ 1.00 \quad 1 / 2$ oz. 60 c. Pkt. 25c.

Orange Picture (I. and H.) An outstanding advance. The largest and most sunproof pure orange yet raised. Oz. $\$ 2.00 \quad 1 / 2$ oz. $\$ 1.25 \quad$ Pkt. 35c. 


\section{FOR 1931 NOVELTIES SEE PREVIOUS PAGES}

Ruffled Rose. A giant of the ruttled class, a rich shade of rose with salmon sheen. Truly gigantic in size. Six sprays make a bunch more massive than twenty ordmary Peas. Grand for exhibition.
Oz. $\$ 2.00$
$1 / 2$ oz. $\$ 1.25$
Pkt. 35c.

Satin Mauve (Unwin). A clean, deep satiny mauve self, richer and deeper in tone than any other of this color section; large, frilled flowers well placed on long stems.

Packets only, Pkt. (50 seeds) 50c.

Sweet Seventeen (Carter). First Prize in the novelty class in the N.S. P. S. Show at Bournemouth under the name of The Duchess. It is an entirely new shade. The delicate cream ground, combined with pure blush pink, suggests the freshness of English girlhoodthus it was renamed Sweet Seventeen. Should be included in every collection.
Oz. $\$ 3.00$
$1 / 2$ oz. $\$ 1.75$
Pkt. 50c.

Tally Ho! (King). A color that has captured the keen exhil hitor's eye; brilliant, bright cherry cerise. Five-flower stems of huge blooms are freely produced.
Oz. $\$ 3.00$
$1 / 2$ oz. $\$ 1.75$
Pkt. 50c.

The Admiral (Cullen). twart of Merit, N. S. P. S. The largest and best navy blue Sweet Pea. The plant is vigorous and free Howering. The long stems carry four to five very large blossoms, beautifully frilled. Does not burn.
$\mathrm{Oz} . \$ 3.00$
$1 / 2$ oz. $\$ 1.75$
Pkt. 50c.

The Fawn (Burpee). The Faron, in our opinion, is the most ravishing ever known in Sweet Peas. It is a combination of yellow and pink, perfectly blended in an exquisite shade of chamois pink suffused with amber. The coloring is different from any other Sweet Pea in existence.

Packets only; Pkt. (50 seeds) 50).

Violet Gem (Bolton). Award of Merit, N. S. P. S. Violet $\mathrm{Gem}$ is violet, rich and lustrous, with a melting suffusion of the wine tints, magnificent in size and substance. Unequalled under artificial light.

Oz. $\$ 3.00 \quad 1 / 2$ oz. $\$ 1.75$ Pkt. 50c.

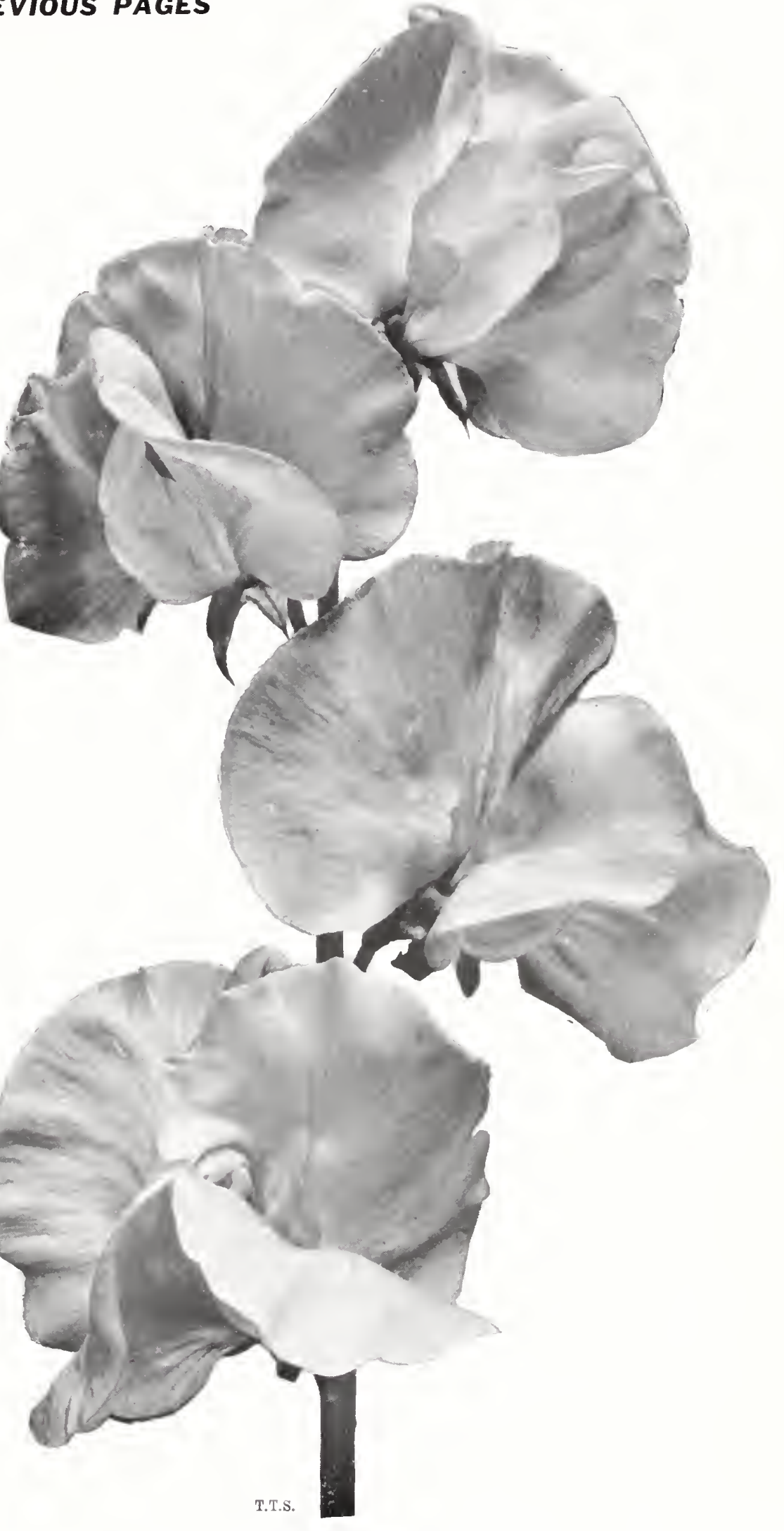

FOR THE GENERAL LIST OF SWEET PEAS

NEW SWEET PEA

SEE OUR REGULAR SEED CATALOG 


\section{EARLy-Flowering Greenhouse SWeet Peas \\ EARLY FORCING SORTS \\ TREATED O SEEDS}

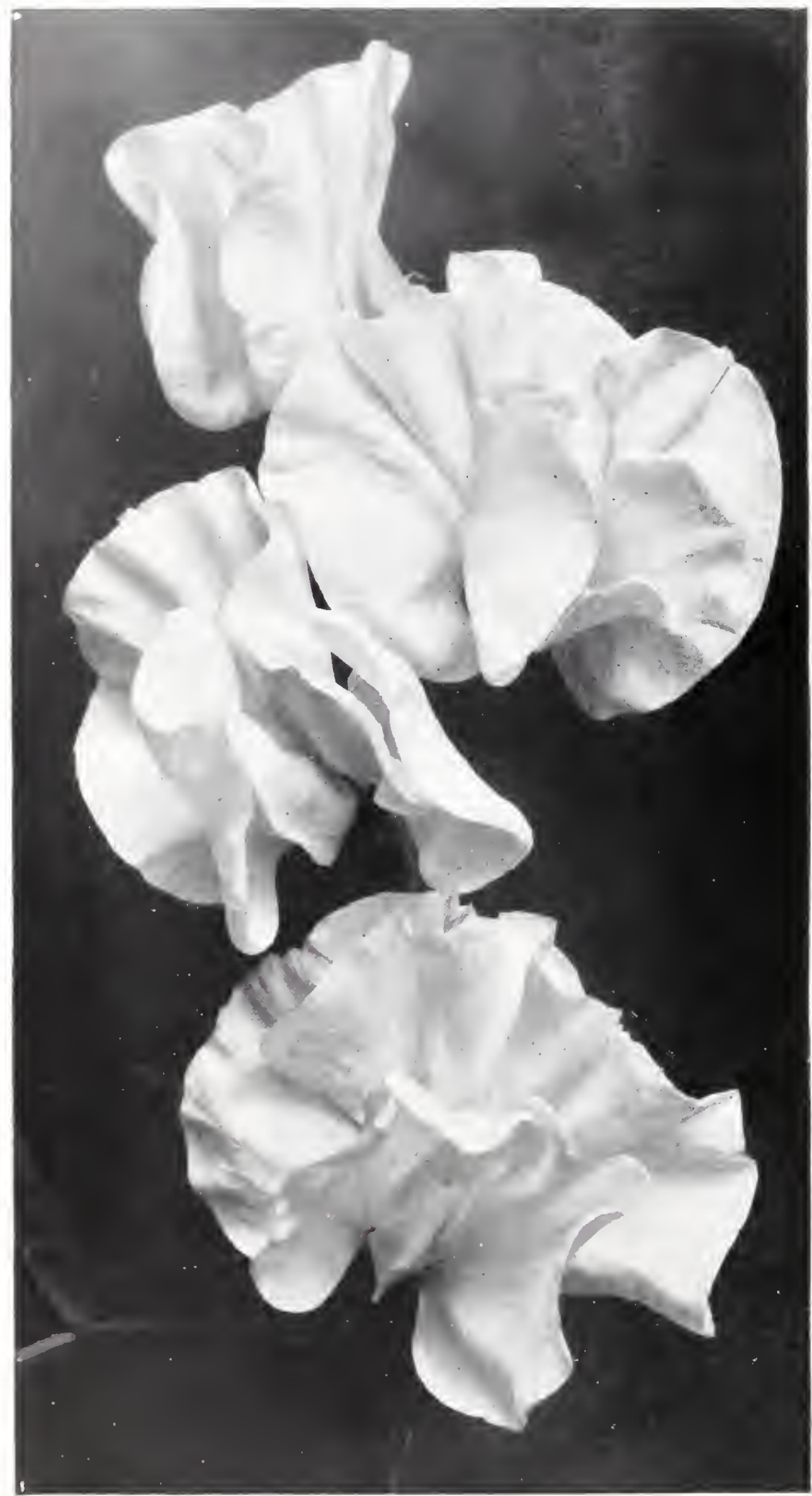

T.T.S.
Early Apollo (Long Stem). One of the new race of long-stemmed early Sweet Peas. The color is soft salmon cerise, or soft salmon pink. Flowers are unusually large, nicely waved and splendidly placed on long, sturdy stems. Awarded Silver Medal, New York Flower Show, 1930; Certificate of Merit, Chicago Flower Show, 1930.

Oz. $\$ 3.00 \quad 1 / 2$ oz. $\$ 1.75 \quad$ Pkt. 60c.

Early Pal (Long Stem). Scintillating, rich rosy crimson, beautifully formed, large blossoms on the newly developed long-stemmed type. Silver Medal, New York Flower Show, 1930: Certificate of Merit, Chicago Flower Show, 1930.

Oz. $\$ 3.00 \quad 1 / 2$ oz. $\$ 1.75 \quad$ Pkt. 60 c.

Early Vogue (Long Stem). Charming, sweet-scented lavender. The flowers are large, beautifully waved and well placed on long stems. Certificate of Merit, Chicago Flower Show, 1930.

Oz. $\$ 3.00 \quad 1 / 2$ oz. $\$ 1.75 \quad$ Pkt. 60c.

Early Oriental. Splend d blackseeded, deep rich cream without the slightest trace of pink. The large flowers appear in fours on long, sturdy stems. The best creamy yellow to date.

Oz. $\$ 2.00 \quad 1 / 2$ oz. $\$ 1.25 \quad$ Pkt. 50c.

Early Marine. The clearest of all blues. A real true blue self; immense blossoms well placed on long, sturdy stems, freely produced over a long period of time. Certificate of Merit, New York Flower Show, 1930.

Oz. \$2.00 1/2 oz. \$1.25 Pkt. 50c.

Early Red Bird. Bright crimson red with a velvety sheen of 'Tyrian rose; very large, free flowering, and long stemmed. Red Bird was awarded a Silver Medal and four Certificates of Merit. Oz. $\$ 3.50 \quad 1 / 2$ oz. $\$ 2.00 \quad$ Pkt. 60c.

Early Silver King. Campanula blue, clear silvery blue, a fascinating new shade. Beautifully formed large blossoms; free flowering and sturdy. Awarded four Certificates of Merit. Oz. $\$ 3.50 \quad 1 / 2$ oz. $\$ 2.00 \quad$ Pkt. $60 \mathrm{c}$.

For other choice Greenhouse Sweet Peas, please refer to our General Seed Catalogue

TREATED $O$ SEEDS

ALL SWEET PEA SEEDS SOLD BY US ARE TREATED WITH A SPECIAL PREPARATION OF OUR OWN, AS A PREVENTIVE AGAINST SEED CARRIED DISEASES 


\section{TROLLIUS (Globeflower)}

Perennial. Cutting and borders.

Ledebouri, Golden Queen. The

plant is very vigorous, grows from 3 to $t$ feet in height, but its chief value lies in the size of the flowers and the intense orange color, the extreme floriferousness and the constancy with which it flowers in Autumn as well as early Summer. It comes practically true to type from seed. Most Trollius are rather uncertain to raise from seed when sown in Spring, but one of the greatest recommendations this introduction has, is that the seed germinates freely when sown in the Spring. Trollizs ledebouri Golden Queen received an Award of Merit from the R. H. S.

Pkt. 50c.

\section{TROPAEOLUM}

\section{TRIVETT'S BABY TYPE}

A charming annualfor bedding, edging, etc

This type may be described as miniature dwarf Nasturtiums, forming small, conpact plants about 6 inches high with small leaves and small flowers in great profusion.

Trivett's Baby Rose. Creamy white with bright rose pink spots.

Trivett's Baby Cherry. Wine red.

Trivett's Baby Scarlet. Bright color.

Trivett's Baby White. Creamy white.

Trivett's Baby Mixed. A grand mixture of all colors including many leading shades. Each of above, oz. 50c.

\section{TROPAEOLUM lobbianum}

\section{(Lobb's Nasturtium)}

A climbing annual Nasturtium with small flowers and small, dark leaves. French Hybrids. A fine mixture of attractive colors with dark colored leaves.

$\mathrm{Oz} .35 \mathrm{c}$.

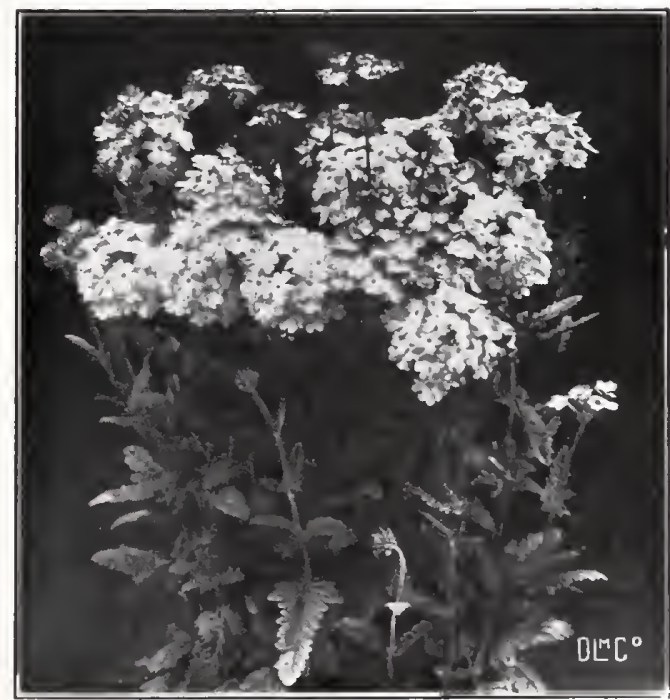

NEW VERBENA. Trivett's Golden Yellow
Anmal. Bedding and cutting.

New annual Daisy from South Africa, growing about 1 foot high; the orange colored Howers measure about 2 inches across and each have a deep purple zone around the center. Makes a good pot plant for the greenhouse. If grown outside, give a sunny position. Try this orange Daisy combined with Heliophila as vase decoration. Pkt. 25c.

\section{VENIDIUM fastuosum}

Anmual. For cutting. 21/2 feet.

Another South African introduction, similar to a large single Calendula. The rich orange flowers are marked with a black purple center and are borne on stout stems; splendid for cutting. A good cut flower for the greenhouse. In the garden, give a sunny position. Pkt. 50c.

VIOLA TREATED SEEDS

Biennial. Bedding, edging, etc.

Avalanche. A white bedding Viola which comes perfectly true from seed; forms compact plants which practically cover themselves with large, round shaped white flowers. (Illustrated.) 5 pkts. $\$ 2.00$ Pkt. 50c.

Complete list of l'iolas, see our

$$
\text { General Seed Catalogue }
$$

\section{VOLETS (Sweet Violets)}

Perennial. Rockeries, woodland, etc.

Odorata, The Czar. Large fragrant deep violet Howers. Pkt. 50c.

Sweet Purple. Rich purple color.

Mixed. Many sorts in mixture. Ideal for sowing on banks of pools, under trees, etc. Sweet scented.
Oz. $\$ 3.00$
$1 / 4$ OZ. $\$ 1.00$
Pkt. 20c.

VIOLA tricolor

\section{(Old-fashioned Wild Pansy)}

Johnny-Jump-Up. The probable ancestor of the modern Pansy, also known as "None-So-Pretty". Purple, blue and yellow are the three colors that give them their name and the combinations are variable. Sometimes there will be a yellow blossom and below it on the sime stalk one of yellow and blue, etc. Ideal for naturalizing beside pools, in woodlands. shady rockeries, as a ground cover for Ir is beds and other naturalized plantings. The tiny flowers first appear during early Spring. Hardy perennial. Use seed liberally when sowing in woodlands

$0 z .81 .50 \quad 1_{4} \mathrm{Oz} .50 \mathrm{c}$. Pkt 10c.

\section{VERBENA TESTED SEEDS}

Annual. For bedding, edging, etc.

Massive Salmon. Lovely new rich color, extra large florets in massive bunches. The florets have a distinct white eye. Cones true from seed.

Massive Royal Blue. "Improved Royale".) Rich velvety royal blue with attractive, creamy yellow eye. P. 35c.

Trivett's Golden Yellow. A new sort which we consider the best yellow so far introduced.

Oz. $\$ 6.00 \quad 1 / 4$ oz. $\$ 1.75$ Pkt. 35c.

\section{ZINNIA, Lilliput $\bigcirc \underset{S E E D S}{T E S T E D}$}

Annual. Bedding and cutting.

Canary Gem. Pale soft yellow.

Crimson Gem. Rich deep red.

Golden Gem. Golden yellow:

Salmon Gem. Lovely salmon rose.

Scarlet Gem (Red Ridixg Hood). lery attractive.

Purple Gem. Rich deep purple. Each, 1/4 0z. $\$ 1.00$ Pkt. $35 \mathrm{c}$.

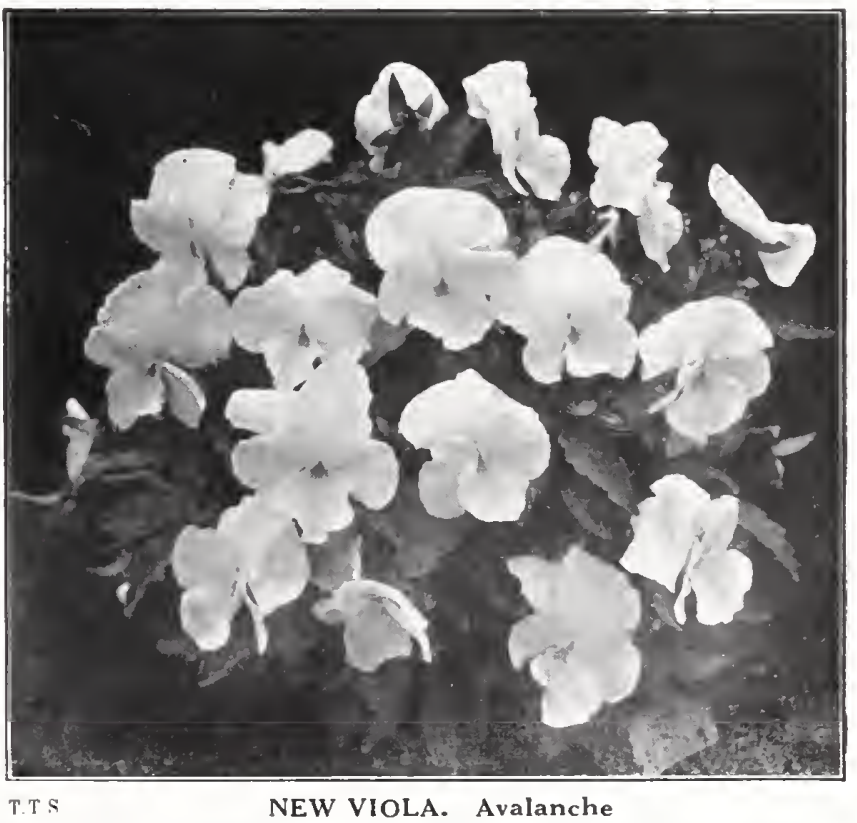




\section{We Offer Only Top Size Bulbs, the Cream of the Crop}

TREATED O BULBS The planting stock from which our choice Gladiolus Bulbs are produced are especially treated before planting, and again, we treat the bulbs before shipping to our customers

\section{LARGE-FLOWERING TYPE}

Aida.

Vew art shades.

Striking dark velvety blue with two small lilac blotches in throat. Medium size flower. Early bloomer.

$100 \times 5.00 \quad 25 \$ 20.00 \quad$ Dos. $\$ 11.00$

American Beauty. Deep rose. Brilliant American Beauty Rose color with creamy yellow throat, large Hower and strong, straight stem.

$100 \$ 10.00 \quad 25 \$ 2.75 \quad$ Doz. $\$ 1.50$

Anna Eberius. Velvety purple, with clark Bordeaux center. Large Howers on fine, strong stems.

$100 \$(6.50) \quad 25 \$ 1.75 \quad$ Doz $\$ 1.00$

Anthony B. Kunderd.

Amthony B. Kumderdis primose yellow with pink edges; heavily ruffled. A rare beauty.

$100 \$ 12.00 \quad 25 \$ 3.25 \quad$ DOz $\$ 1.75$

\section{Autumn Fascination.}

Sce Herbstzauber.

\section{Bengal Tiger. New art shades.} A peculiar dull red with dusky bluish gray stripes; a very striking variety. $100 \$ 8.50 \quad 25 \$ 2.25 \quad$ Doz. $\$ 1.25$

Betty Nuthall. Light coral, with pale orange throat and a light feathering of carmine. Flowers often 6 inches across. Of splendid substance and well placed on tall, strong spikes. One of the best of later introduction. $100 \$ 75.00 \quad 25 \$ 20.00 \quad$ Doz. $\$ 11.00$

\section{Break o'Day.}

Sof t pink, or La France Pink flushed with cream. Tips of petals are a deeper shade of pink and there is a zone of light yellow. on lower petals with delicate center line of red. lery early flowering. $100 \$ 7.00 \quad 25 \$ 2.00 \quad$ Dоз. \$1.25

\section{Capt. Boynton.}

Lavender, with deeper blotch on lower petals. l'erfectly placed large flowers, strong stems.

$100 \$ 12.00$

$25 \$ 3.50$

Dos. $\$ 2.00$

Chateau Thierry. Orange red, with yellow border blotch of red on lower petals; fine flowers; tall spikes. $100 \$ 6.0(1) \quad 25 \$ 1.75 \quad$ Doz. $\$ 1.00$

\section{Conspicuous. Nerv art shades.}

l.ight blue with dark l'ansy blue blotch in throat which is bordered with yellow. Giacs the impression of a Pansy. $100 \$ 7.50 \quad 25 \$ 2.00 \quad$ Doz. $\$ 1.25$

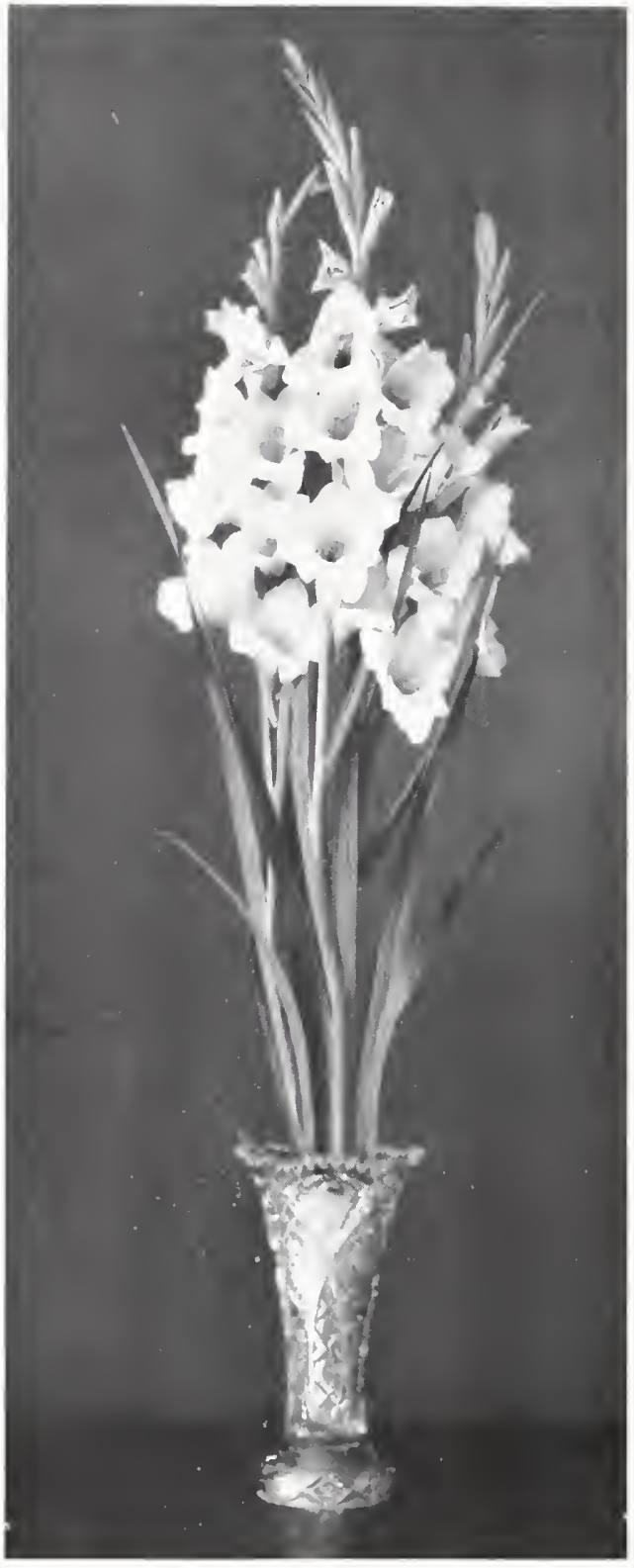

GOLDEN DREAM

\section{NOTE}

Varieties not listed may be found in our General Catalogue

A copy will be gladly sent on renuest

TRIVETT'S TESTED SEEDS, INC. New York City
Dr. F. E. Bennett. Peach red, overlaid with flame scarlet, throat speckled with ruby and creamy white; very large flowers of great substance Many open at a time on strong stalk; sturdy, healthy grower.

$100 \$ 14.00 \quad 25 \$ 4.00 \quad$ Doz. $\$ 2.50$

Dr. Moody. Lavender pink. A lovely shade with faint markings on lower petals. Almost a self color. Tall, straight spikes with $S$ or 10 blooms open at a time. It also produces several side spikes. Very attractive.

$100 \$ 40.00 \quad 25 \$ 11.00 \quad$ Doz. $\$ 6.00$

Emile Auburn. New art shades. Indescribable blend of rose and orange with a slaty gray overtone; scarlet and rose blotch on lower petals. A long spike of well placed flowers of most unusual coloring.

$100 \$ 25.00 \quad 25 \$ 6.50 \quad$ Doz. $\$ 3.50$

Fern Kyle. Creamy white. Large, heavily ruffled flowers, many open at same time, on long, strong, stems. A wonderful and very refined variety.

$100 \$ 10.00 \quad 25 \$ 2.75 \quad$ Doz. $\$ 1.50$

Geraldine Farrar. Lavender blue of pale shade with deep violet blotch on lower petals. Very choice sort.

$100 \$ 25.00 \quad 25 \$ 6.50 \quad$ Doz. $\$ 3.50$

Giant Nymph. Light rose, with creamy yellow throat; very large, widle open flowers well arranged on long, straight stems. Grows about 6 feet tall.

$100 \$ 6.50 \quad 25 \$ 1.75 \quad$ Doz. $\$ 1.00$

Golden Dream. Pure yellow, a clear golden yellow much better than Golden Measure. This variety is now the leader in its class.

$100 \$ 18.00 \quad 25 \$ 5.00 \quad$ Doz. $\$ 2.75$

Heavenly Blue. Pale blue, or delicate lavender blue; large flowers on strong, graceful stems; a variety of great refinement and elegance. A truly gorgeous color.

$100 \$ 150.00 \quad 25 \$ 40.00 \quad$ Doz. $\$ 22.00$

Henry Ford. Dark purple, a shade known as rhodamine purple; dark velvety Plum rose, good strong spikes.

$100 \$ 7.50 \quad 25 \$ 2.00 \quad$ Doz. $\$ 1.25$ 


\section{LARGE FLOWERING GLADIOLUS - Continued}

\section{TREATED $\bigcirc$ BULBS \\ Top size bulbs only the largest procurable of each variety}

Herbstzauber. Salmon copper. A lovely warm shade of color. Very large flowers of exquisite form; tall growing and late in tlowering.

$$
100 \$ 35.00
$$

$25 \$ 9.00$

Doz. $\$ 5.00$

Jack London. Light salmon, with vermilion stripes and canary yellow throat. Perfectly placed flowers on strong, stems. Robust grower.

$100 \$ 7.00 \quad 2582.00 \quad$ Doz. $\$ 1.25$

Joe Coleman. Bright red, with carmine blotch; very attrac tive, large ruffled flowers, many open at one time; good, strong grower.

$100 \$ 6.00 \quad 25 \$ 1.75 \quad$ Doz $\$ 1.00$

Joerg's White. Snow white, the lower petals shade to creamy yellow in the throat. One of the largest flowers and almost as goorl as Mammoth l'hite.

$100 \$ 10.00 \quad 25 \$ 11.00 \quad$ Doz. \$6.00

John T. Pirie. New art shades. Rich mahogany brown with yel low bearded brown throat. medium size; color combination reminds one of a dark, rich colorerl Japanese lris. Most unusual and will command attention.

$100 \$ 14.00 \quad 25 \$ 4.00 \quad$ Dos $\$ 2.50$

Lilac Wonder. Lavender Pure delicate lavender; tall, straight spikes, flowers well placerl. The nicest shade we have yet seen in Gladiolus.

$100 \$ 19.00 \quad 25 \$ 5.00 \quad$ Doz. $\$ 3.00$

Longfellow. Clear pink. A lovely shade of La France Pink. Tall, graceful wire spikes of large. wide open blossoms. Does not wilt or burn in the hottest weather. lery choice.

$100 \$ 25.00 \quad 25 \$ 0.50 \quad$ Doz $\$ 3.50$

Los Angeles. Shrimp pink, with glowing orange pink blotch in throat; tall, strong stems. Isually two spikes to a bulb. $100 \$ 6.50 \quad 25 \$ 1.75 \quad$ Doz. $\$ 1.00$

\section{Mme. Mounet Sully.}

White, or milky white with a large orange blotch. Flowers well arranged on good stems. A very attractive variety.

$100 \$ 45.00 \quad 25 \$ 11.50 \quad$ Doz. $\$ 6.00$

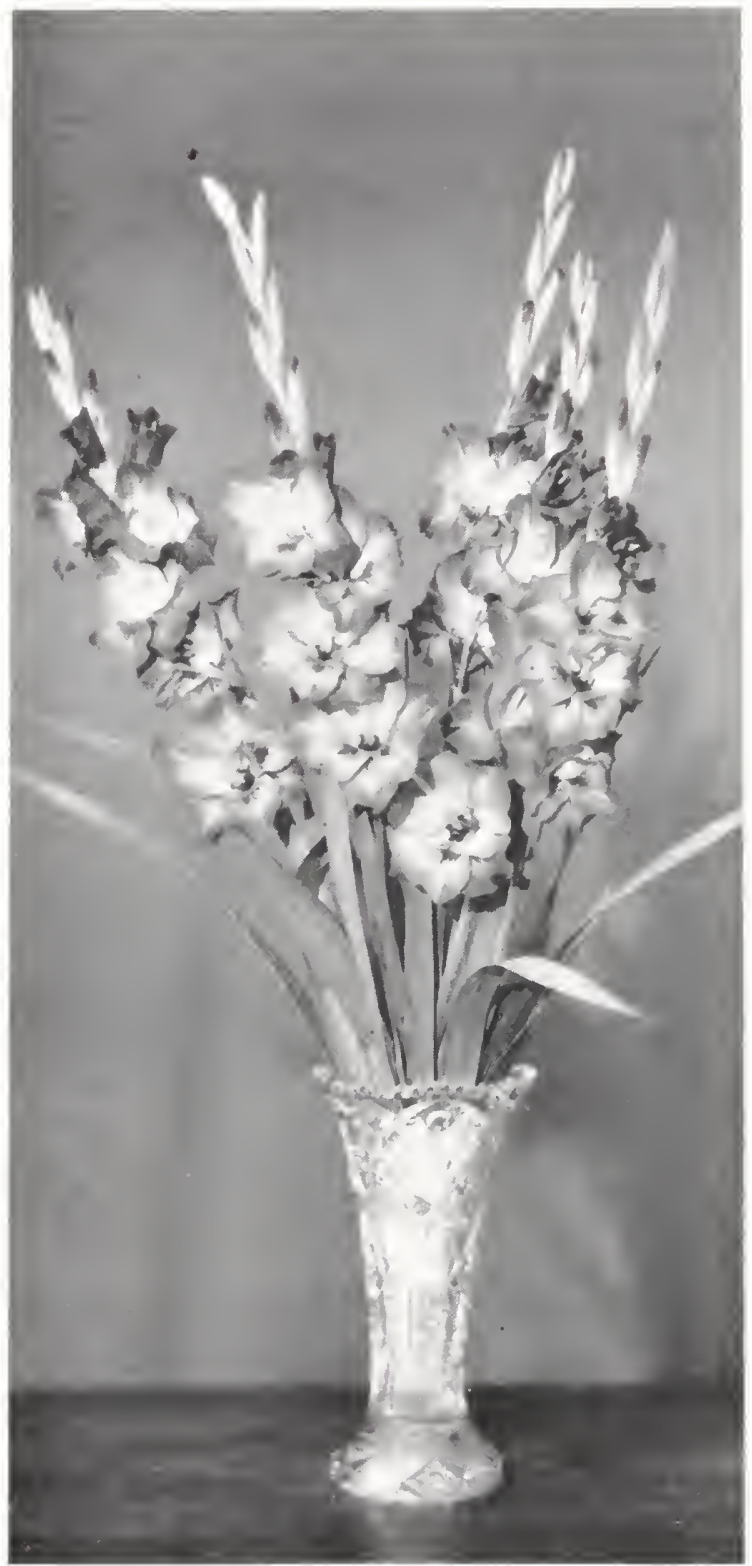

MRS. LEON DOUGLAS
Minuet. Light lavender, a beatiful clear shade. Extra large, heavily textured blooms on very strong stems. This is the lavender by which all lavender Gladiolus are judged. Considered by most growers as the best in its color class.

$100 \$ 40.00 \quad 25 \$ 11.00 \quad$ Doz. \$6.00

Mr. W. H. Phipps. Pink. A charming shade of La France Pink overlaid with a delicate wash of soft salmon rose, lighter towards the center, lower petals faintly striped and speckled with ruby. Very large flowers on extra heary stems.

$100 \$ 1+.00 \quad 25 \$ 1.00 \quad$ Doz. $\$ 2.25$

Mrs. F. C. Hornberger.

White. A pure white without any markings; nicely ruffled, wide open flowers on sturdy spike. $100 \$ 23.00 \quad 25 \$ 1.00 \quad$ Doz. $\$ 3.50$

Mrs. F. C. Peters. Lilac pink with purplish blotch in throat many large flowers open at a time on erect stems.

$100 \div 3.00 \quad 25 \$ 2.50 \quad$ Doz. $\$ 1.50$

Mrs. Leon Douglas.

Begonia rose, striped with flame scarlet, lower petal pale vellow speckled with ruby; tremendously large flowers; many open at same time: very tall, strong stems. Considered one of the finestGladiolus in existence.

$100 \$ 7.50 \quad 25 \$ 2.00 \quad$ DOs. $\$ 1.25$

Mrs. Van Konynenburg.

Aniline blue, lovely color; the best by far of any blue variety. frows 5 feet tall; stems erect; flowers well placed, even the very last top flower opens up in its true color. The best blue variety.

$100 \$ 5.500 \quad 25 \$ 1.500$ Doz.s..00

\section{Nancy Hanks. Apricot.} lovely rich apricot changing to orange pink with grenadine tongue. Six or more flowers open at a time. IVell arranged on good stems. Ifill not burn in the hotlest sun. $100 \$ 9.00 \quad 2582.50 \quad$ Dos. $\$ 1.50$

Paul Pfitzer. Velvety purple, massive flowers on very strong stems. Perhaps the finest dark purple Crladiolus.

$100 \$ 65.00 \quad 25 \$ 1 \$ .00 \quad$ Doz. $\$ 10.00$

Persia. Dark mahogany. An unusual color, deep rich ma-

Mammoth White. White. Pure paper white, the largest flower of any Gladiolus we know of, measuring 7 inches in diameter. Straight spikes 5 feet tall, many flowers open at the same time.

$$
100 \$ 250.00 \quad 25 \$ 65.00 \quad \text { Dos. } \$ 34.00
$$

Marmora. Lavender gray, with Petunia colored blotch. From \& to 12 very large flowers open at same time on tall, strong stem. One of the best Gladiolus ever introduced.

$$
100 \$ 75.00 \quad 25 \$ 20.00 \quad \text { Doz. } \$ 11.00
$$
$\begin{array}{lll}100 \$ 9.00 & 25 \$ 2.50 & \text { Doz. } \$ 1.50\end{array}$

Pfitzer's Triumph. Orange salmon. Bright orange salmon red with small, velvety red mark in throat. It is absolutely irresistible. Imagine flowers of great substance 6 to 7 inches across placed in a double row on great, strong stalks which grow 5 feet high, the last flower of which will open up true to color. A single spike of this Super Gladiolus equals two or three of any other sort.

$$
100 \$ 4 \times .00
$$$$
25 \$ 12.50
$$

Doz. $\$ 6.50$ hogany red. IVill make a good contrast to the lighter colored sorts. 


\section{GLADIOLUS-Continued}

Phaenomen. A beautiful Gladiolus, the color blending of salmon pink and rich yellow is indeed charming. Perfectly placed flower on good, strong stems.

$$
100 \$ 14.00 \quad 25 \$ 3.75
$$

Doz. $\$ 2.00$

President Harding. Large wine red flowers shaded lighter toward the center. The throat is speckled with deep maroon red, with two small yellow stripes on lower petals. As many as 20) flowers on the spike; very strong, sturdy, tall spikes.

$$
\begin{array}{lrl}
100 \$ 19.00 & 25 \$ 5.00 & \text { Doz. } \$ 3.00
\end{array}
$$

Purest of All. A splendid pure white variety of large size; straight spikes with well placed flowers.

$$
100 \$ 25.00 \quad 25 \$ 6.50
$$

Doz. $\$ 3.50$

Purple Glory. Deepest velvety maroon with almost black blotches; large ruffled flowers on very tall, sturdy stems. A real giant in all respects.

$$
100 \$ 12.00 \quad 25 \$ 3.25 \quad \text { Doz. } \$ 1.75
$$

Rex. Brilliant scarlet, tremendously big flowers on enormous stems; one of the largest and tallest of all Gladiolus.

$$
100 \$ 25.00 \quad 25 \$ 6.50 \quad \text { Doz. } \$ 3.50
$$

Richard Diener. Geranium pink with creamy yellow center, flaked with carmine. Immense ruffled flowers on tall, stately spikes.

$$
100 \$ 9.00 \quad 25 \$ 2.50 \quad \text { Doz. } \$ 1.50
$$

Rita Beck. A clear shell pink with scarlet lines on lip. Immense blooms, six to eight open at a time on tall, erect stems. Truly a super Gladiolus.

$$
100 \$ 60.00 \quad 25 \$ 16.00 \quad \text { Doz. } \$ 9.00
$$

Romance. Another charming art shade sort; orange salmon rose with red and yellow throat. A bluish border surrounds each petal. Medium sized flowers. The color combination will not fail to command admiration.

$$
100 \$ 6.50 \quad 25 \$ 1.75
$$

Doz. $\$ 1.00$

Saraband. Very large, wide open flowers of rich velvety wine color, with deep yellow blotch; tall spike. A very unusual flower.

$$
100 \$ 30.00 \quad 25 \$ 8.00 \quad \text { Doz. } \$ 4.25
$$

Scarlet Wonder. Purest deep scarlet, mammoth flowers; many open at one time. Tall, stiff stems. Truly a real giant.

$$
100 \$ 9.00 \quad 25 \$ 2.50 \quad \text { Doz. } \$ 1.50
$$

Sidney Plummer. Soft yellow suffused with delicate pink; the throat is slightly marked with amaranth purple. A ruffled giant.

$$
100 \$ 12.00 \quad 25 \$ 3.50 \quad \text { Doz. } \$ 2.00
$$

Sunnymede. Beautiful shade of orange yellow with rich red blotch; tall spike with many flowers open at one time.

$$
100 \$ 16.00 \quad 25 \$ 4.50 \quad \text { Doz. } \$ 2.50
$$

Sweet Lavender. Light lavender with purple throat; one of the earliest to bloom and a very attractive variety.

$$
100 \$ 9.00 \quad 25 \$ 2.50 \quad \text { Doz. } \$ 1.50
$$

Trudel Grotz. Glowing salmon pink with small red blotch in throat; enormous flowers on strong stems. Good, strong, healthy grower.

$$
100 \$ 25.00 \quad 25 \$ 6.50
$$

Doz. $\$ 3.50$

Veilchenblau. Deep violet blue, much larger than Baron Hulot, and perhaps the finest in its color class.

$$
100 \$ 95.00 \quad 25 \$ 24.00
$$

Doz. $\$ 13.00$

White Giant. Tall, sturdy spikes displaying very large white flowers of great substance. One of the largest and best white Gladiolus.

$$
100 \$ 12.00 \quad 25 \$ 3.50
$$

Doz. $\$ 2.00$

Yellow Wonder. Pure soft yellow; large flowers without any markings. Strong, healthy grower. Nezu German variety. $\$ 1.75$ each.

Virginia. Flaming scarlet, large, massive flowers, many open at a time, making a gorgeous display of dazzling red.

$$
100 \$ 5.00 \quad 25 \$ 1.50
$$

Doz. $85 \mathrm{c}$

FOR OTHER VARIETIES, PLEASE REFER TO OUR GENERAL CATALOGUE. A COPY WILL BE SENT ON REQUEST
NEW SCOTCH GLADIOLUS

\author{
Originated in Scotland
}

These are really sensational in every way; tall, massive spikes showing many flowers open at one time.

Berty Snow. Strong, upright spike showing 6 to 8 very large, fully developed flowers open at one time; lovely, light rosy lavender with white blotch in throat.

David Airdrie. Strong and vigorous, with \& large blooms open at once; rich, deep rose tinted with yellow in throat.

King George. Glowing scarlet with contrasting yellow throat $\&$ flowers open at one time. A strong grower of special merit.

Lillie. Pale mauve, suffused with small white blotch; long, wiry flower spikes rigid and upright.

Marvel. Immense flowers, well placed on sturdy stems; white, edged with pink; canary yellow throat. Truly a mareel.

Mrs. Galbraith. Magnificent blooms of rich salmon; pale yellow throat penciled and spotted with rose; 6 to 8 fully expanded flowers at one time.

\section{Price: Any of above Scolch zarieties, Doz. 823.00 Each $\$ 2.00$ \\ CHOICE PRIMULINUS HYBRIDS} and Rare Hybrids

Annie Laurie. Heavily ruffled, delicate pink washed over with light rose pink and with light heliotrope lines in throat. One of the most exquisitely beautiful Gladiolus in existence.
$100 \$ 25.00$
$25 \$ 6.50$
Doz. $\$ 3.50$

Butterboy. Clearest buttercup yellow, large open flowers on tall, straight stems; very vigorous plant.

$$
100 \$ 7.00 \quad 25 \$ 2.00 \quad \text { Doz. } \$ 1.25
$$

Carara. Creamy white on tall, erect stems. Good for contrast $100 \$ 10.00 \quad 25 \$ 2.75 \quad$ Doz. $\$ 1.50$

Copper Bronze. Deep salmon bronze orange overlaid with a coppery shade, tips of petals deep bronze. Unique and dazzling.
$100 \$ 19.00$
$25 \$ 5.00$
Doz. 82.75

Dorothy Wheeler. Pure delicate rose pink, the flowers are well placed on slender, graceful stems.

$$
100 \$ 6.00 \quad 25 \$ 1.75 \quad \text { Doz. } \$ 1.00
$$

Jewell. Light salmon pink with beautiful golden yellow throat; large, wide open flowers; good stems; most attractive sort.
$100 \$ 6.00$
$25 \$ 1.75$
Doz. $\$ 1.00$

Mrs. Calvin Coolidge. Very soft salmon rose pink, lower petals creamy yellow bordered same shade of pink as upper petals. A Grandiflora Primulinus, unsurpassed in its class. Doz. $\$ 15.00$

Orange Queen. Apricot orange, a color that does not exist in any other variety; open flowers on good stems. Considered one of the finest of recent introduction.

$$
100 \$ 9.00 \quad 25 \$ 2.50 \quad \text { Doz. } \$ 1.50
$$

Patricia Carter. Softest light shrimp pink; no markings whatsoever; one of the best Primulinus ever introduced. A real beauty.

$$
100 \$ 75.00 \quad 25 \$ 20.00 \quad \text { Doz. } \$ 11.00
$$

Primunella. Grand ruffled Butterfly or Orchid type, orange saffron with yellow; very beautiful and one of the best.

$$
100 \$ 9.00 \quad 25 \$ 2.50 \quad \text { Doz. } \$ 1.50
$$

The Orchid. A new type of Gladiolus. Petals slightly notched and ruffled; color is orchid over white with rose lilac feathering in throat. The most Orchid-like Gladiolus in the world. $100 \$ 18.00 \quad 25 \$ 4.75 \quad$ Doz. $\$ 2.50$

Topaz. Buft orange, pure self color; tall, graceful spikes. Very attractive.

$100 \$ 6.00 \quad 25 \$ 1.75 \quad$ Doz. $\$ 1.00$ 


\section{"Best by test" DAHLIAS of Superior Merit \\ THE FOLLOWING VARIETIES ARE NOT LISTED IN OUR GENERAL CATALOGUE}

Dec-Decorative
Cac.-Cactus

Cardinalis. $D e c$.

Cardinal red. Attractive, brilliant color. Splendidly formed flowers on strong, upright stems. Tuber $\$ 8.00$

Plant $\$ 1.00$

Chemer's Eureka. Dec. White. The tips of the center petals are slightly touched with lavender. An excellent exhibition sort.

Tuber $\$ 5.00$

Plant $\$ 2.50$

Chemer's Blue Gem. Dec. Purple. A bluish purple, large blooms held erect on long, strong stems.

Tuber $\$ 5.00$

Plant $\$ 2.50$

Color Sergeant. $D e c$.

Bronze, washed over with salmon. A lovely, deep salmon bronze; clean, upright grower of excellent habit; fine, strong stem; one of the best for exhibition.

Best specimen bloom, State Show, New Jersey Silver Medal at Philadelphia.

Certificale of Merit, $N$. J. State Trials Tuber $\$ 5.00$

Plant $\$ 2.50$

City of Trenton. Dec. Orange. Glowing tangerine orange, reverse of petals crushed strawherry red. A lovely 'Autumn' shade. The large exhibition blooms are held erect on cane-like stems.

Tuber $\$ 5.00$

Plant $\$ 2.50$

Conquistador. H.C. Yellow. A soft creamy yellow showing pink at the base of the petals; fine, large blooms; good stems.

Tuber $\$ 5.00$

Plant $\$ 2.50$

Dr. John Carmen. $D e c$. Red, or a 'deep 'American Beauty' rose. A very vigorous grower with large blooms on strong, stout stems.

Tuber $\$ 500$

Plant $\$ 2.50$

\section{Dorothy Stone.}

Pink.

Beautiful rose pink; one of the finest of this color; healthy grower. Large blooms of good formation, and splendid stems. Tuber $\leqslant 5.50$

Plant $\$ 4.00$

\section{Elite Gem.}

Pink. Spinel pink blush on pale yellow at the base, the reverse of petals is rosaline purple. Tuber $\$ 2.00$ Plant $\$ 1.00$

\section{Grace Curling.}

Lavender.

A lovely shade of Cattleva lavender shading to white at the base of petals, a beaut ifully formed bloom of large size on splendid, strong stem.

Tuber $\$ 7.50$

Plant $\$ 4.00$

Jean Trimbee. H.C. Violet. A lovely shade of l'etunia violet; strong, healthy growth, well formed flowers and good straight stems.

Tuber $\$ 1000$

Plant $\$ 5.00$
Jersey's Glory. Dec. Orange. A soft shade of yellow orange; a strong. healthy grower, finely formed flowers on long, strong stems.

Tuber $\$ 5.00$

Plant $\$ 2.50$

Jersey's Triumph. $D e c$. Copper, washed with salmon, creating a fine shade growth as Jersey's Beauty, possessing the same splendid qualities.

Tuber $\$ 5.50$

Plant $\$+00$

Kathleen Norris. Dec. Pink. Immense, finely formed blooms of true rose pink color. A very vigorous growing, healthy sort. The gigantic exhibition flowers are held erect on exceptionally. heavy, strong stems.

Tuber $\$ 10.00$

Plint 5.5 .00

Katherine Cole. Dec. Pale pink. Soft blush pink and cream combination. A very lovely sort on long, cane-like stems. A prize winner in the long lasting cut flower class.

Tuber $\$ 10.00$

Plant $\$ 5.00$

La Roda.

Dec.

Silvery pink. An exhibition sort of real merit. lmmense blooms held erect on stout stems. A lovely: shade of soft, silvery rose pink.

Tuber $\$ 7.50$

Plant $\$ 1.00$

Lilac Glory.

Cac. Soft lilac.

A true Cactus in form, the medium sized blooms are produced on fine, strong stems. Tuber $\$ 5.00$

Plant $\$ 2.50$

Mrs. Alfred B. Seal. $D e c . \quad$ Rose. In exquisite shade of old rose. The flowers are immense in size and are held erect on long, stiff stems. One of the finest pure rose pink sorts ever introduced.

Tuber $\$ 10.00$

Plant $\$ 0.00$

Mrs. Kenyon. Dec.

Salmon. A charming shade of salmon pink. Large on stout, strong stems. The cut flowers are long lasting. A grand exlibition sort. Tuber $\$ 5.00$

Plant $\$ 2.50$

\section{Spirit of St. Louis. $D e c$. Rose.} 'American Beauty' Rose color: splendid, large blooms supported with strong stems. A very choice sort.

Tuber $\$ 5.00$

Plant $\$ 2.50$

Treasure Island. Dec. Apricot. A charming combination of apricot, gold and rose shades; one of the most lovely. Good, large blooms of exhibition quality. Strong stems and healthy growth.

Tuber $\$ 5.00$ of salmon bronze. The same habit of exhibition blooms beautifully formed and
Watchung Wonder. Der. Red. in the center. An outstanding variety in any first class collection.

Tuber $\$ 7.50$

Plant $\$ 4.00$

White Empress. Dec. White. A splendid, large pure white; vigorous growth, good stems and has long lasting qualities when cut.

Tuber \$.5.00

Plant $\$ 2.50$

Yellow Beauty.

Yellow.

A seedling of Jersey's Beauty, possessing the same splendid stem, fine form and vigorous healthy habit of growth. The yellow Jersey's Beauty.

Tuber $\$ 5.00$

Plant $\$ 2.50$

\section{BABY DECORATIVE Rosette Type}

The following three varieties are gems for cutting purposes and are splendid types of the new small flowered Decorative class. These variet ies should be in every collection.

\section{Irene.}

Old rose.

A charming, small flowered Decorative Dahlia belonging to the rosette or miniature class. The blossoms are only 2 to 3 inches in diameter. The color is an exquisite shacle of old rose; splendid for cutting. Tuber $\$ 1.00$

Little Jewel.

Peach pink. One of the daintiest of the new race of baby Dahlias. Blossoms are about $2^{1}{ }_{2}$ inches in diameter, absolutely perfect in form and of a most entrancing shade of peach blossom pink. Tuber $\$ 1.00$

\section{Pink Pearl.}

Rose pink.

A new miniature flowered Decorative I)ahlia from England. The color is a deeper shade than that of "Little Jewel." The blossonns are carried erect on thin, wiry stems. A charming variety for cut flower purposes and valuable for table decorations. Tuber $\$ 1.00$

\section{Tubers of Dahlias}

are shipped during the early Spring months. If desired for early propaga-

tion, we can make extra early delivery when requested.

\section{Green Plants}

are not shipped out until Mlay and later. 


\section{TRIVETT'S FLOWERING Greenhouse PLANTS}

The Following Varieties are Not Listed in Our General Catalogue

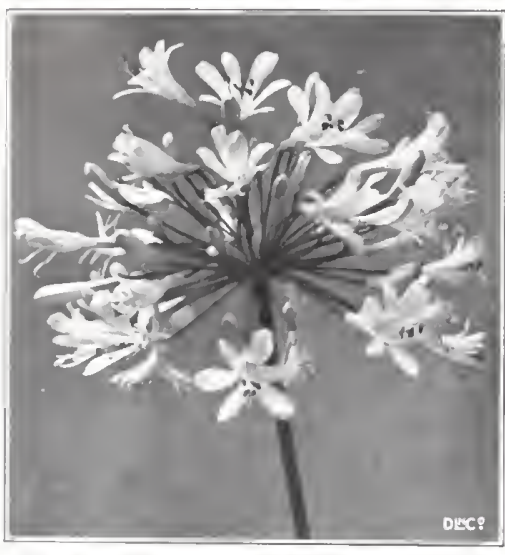

AGAPANTHUS UMBELLATUS

Blue Lily of the Nile

\section{AGAPANTHUS umbellatus}

(Bhue Lily of the Nite)

Splendid decorative plant, bearing clusters of bright blue flowers on stems 3 feet long and lasting a long time in bloom. A most desirable plant for outdoor decoration. planted in tubs on the lawn or piazza.

\section{BEGONIAS} 5 inch pots Each $75 \mathrm{c}$

Argentea Guttata. Foliage of rich green spotted with silver.

Corallina Lucerna.

of bronzy red flowers in b. ously from April to November.

Haageana. Large trusses of creamy white flowers suffused with pink. The foliage is bold and attractive bronzy green on top; underneath is reddish brown.

Price. Any of the above Each $45 \mathrm{c}$.

For other varieties of Begonias please refer to our General Catalogue

\section{BELOPERONE guttata}

\section{(Shrimp Plant)}

The curious plant which attracted so much attention at the New York Spring Flower Show. The plant produces long sprays of bloom, brownish pink in color, at the end of each a small white floret, Very odd and attractive. 3 inch pots Doz. $\$ 6.00$

\section{CALANTHE ORCHIDS}

\section{Easy to Grow}

The easiest of all the Orchids to grow. Flowers November, December, January. Everyone with a greenhouse should grow them.

Calanthe Wm. Murray. Lovely long sprays of beautiful pink and white blossoms on fine long stems.

Calanthe veitchi. Long branching spikes of beautiful rosy pink blossoms. Calanthe regnieri. Lovely white with charming pink center.

Price: Flowering size dormant bulbs in different sizes, any of the above Each \$1.25, \$2.00 and 82.75 according to size

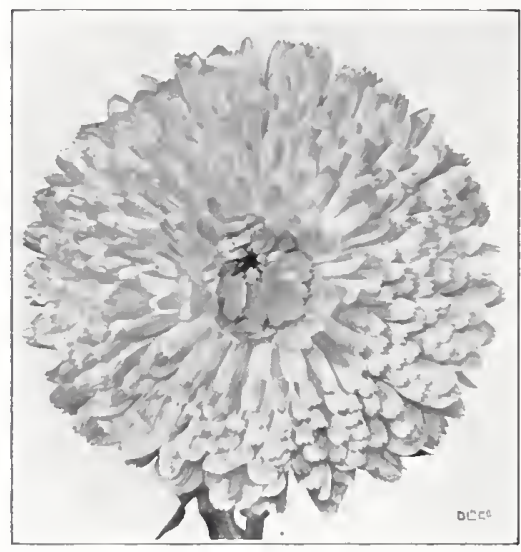

CALENDULA-Sensation

(New Campfire)

CALENDULA, Sensation (New Campfire)

Splendid sort for greenhouse cutting, large blooms of glowing orange with a wash of scarlet. $\quad 21 / 4$ inch pots $100 \$ 15.00$ 3 inch pots $100 \$ 20.00$

\section{CARNATIONS}

Of Recent Introduction

Spicy White. A large pure white, very free, long, stiff stems and an excellent keeper.

Senator. Another splendid white and a tremendous cropper.

Del Ray. In color similar to Ward, with a deeper shade in Spring. Equally as free as Matchless, and possesses splendid keeping qualities. No splits

Potentate. Rich purple color that is quite a novelty; a splendid producer, good size and stem. A high grade Carnation.

Woburn. Considered by many growers as the finest crimson sort.

Price: Any of the above five

Rooted cuttings from January onward $100 \$ 25.00 \quad 25 \$ 7.00$

For other varieties of Carnations please refer to our General Catalogue

\section{CLIVIA miniata}

\section{(Imantophyllum}

Pretty Lily-like flowering plant of the easiest culture. Flowers in Spring and Summer months remaining in bloom a long time. The flowers are borne in large clusters from 10 to 20 flowers each. The color is a fine orange red shading to buff. 4 inch pots Each $\$ 1.25$ 5 inch pots Each $\$ 2.50$

\section{GERBERA, New Double}

\section{New Double Hybrids}

Beautiful form of this desirable cut flower with Anemone-like double centers and in a splendid range of lovely shades. Doz. $\$ 10.00$

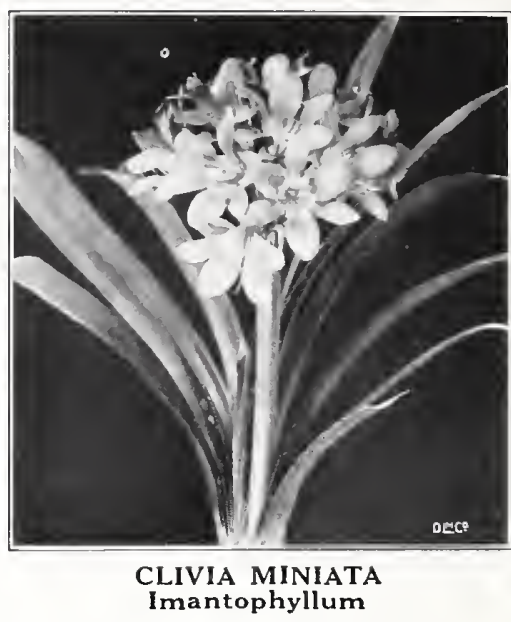

\section{OPHIOPOGON}

Jaburan variegatus. Pretty, variegated foliage plant; useful for pots or planting out in the Summer. Spikes of blue flowers provide a lovely contrast to its gold striped foliage.

Fine plants Each $\$ 1.00$

\section{ROSES}

\section{Baby Sorts for Forcing}

Echo. Lovely soft pink.

Greta Kluis. Double deep pink.

Orleans. Brilliant light red.

Any of above three Each 85c. Doz. $\$ 9.50$

\section{Forcing Climbing Roses}

For training in pots.

Marie Gouchault. Clear, bright Geranium pink, more brilliant than Dorothy Perkins and as easy to grow as Eugene Jacquet.

Eugene Jacquet. Bright carmine, the best and most popular of all climbing Roses for pot forcing.

Each of the above two sorts

$$
\text { Each 90c. }
$$

Doz. $\$ 10.00$

ROSE, Herbert Hoover. The color is a combination of cerise pink, flame scarlet and yellow. Exquisite fragrance. Gold Nedal, International Flower Show, New Fork.

Grafted plants $\quad 100 \$ 60.00 \quad 25 \$ 16.00$

For all other Greenhouse Roses please refer to our General Catalogue

\section{RHODODENDRON}

\section{For Forcing}

Pink Pearl. The best and most popular forcing Rhododendron.

$11 / 2$ to 2 feet high ( 5 buds) Each $\$ 8.50$ 2 to $21 \%$ feet high (7 buds) Each $\$ 15.00$

NOTE. FOR OTHER GREENHOUSE FLOWERING PLANTS, PLEASE REFER TO OUR GENERAL CATALOGUE 


\section{TRIVETT'S ORNAMENTAL Greenhouse PLANTS}

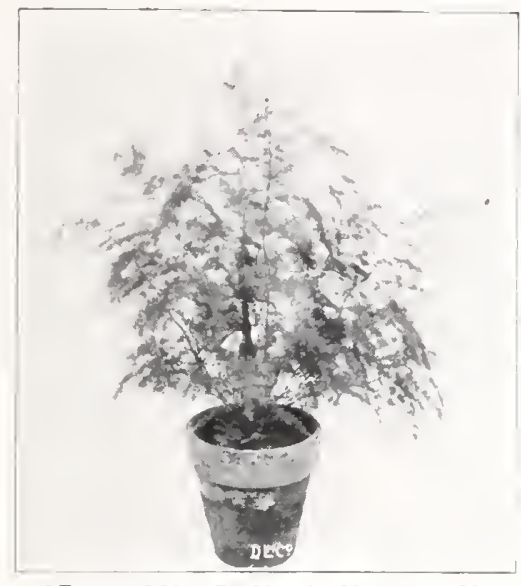

ASPARAGUS PLUMOSUS NANUS

\section{ALO YSIA citriodora}

\section{(Lemon-verbena)}

The well known popular pot plant, richly fragrant foliage.

Doz. s.3.(1)

\section{ANTHERICUM}

Vittatum picturatum. A most desirable plant for window boxes, vases. or as a pot plant. long, narrow green foliage with creamy white center. 5 inch pots Each \$1.2.

\section{ARDISIA crenulata}

Very ornamental greenhouse plant with dark green, glossy foliage, bearing clusters of very brilliant red berries.

Fine 4 inch pot plants Each 81.75

\section{ARAUCARIA excelsa}

\section{Norfolk Island Pine}

Beautiful, tender evergreen; a favorite house plant.

$$
\begin{aligned}
& 4 \text { inch pot plants Each } \$ 2.55 \\
& 5 \text { inch pot plants Each } \$ 3.50 \\
& 6 \text { inch pot planls Each } \$ 4.50
\end{aligned}
$$

\section{ASPARAGUS plumosus nanus}

There is no better plant for table decora tion than this. Ideal material for interspersing between cut flowers, etc. 3 inch pots $100 \$ 25.00 \quad 25 \$ 7.00$

\section{ASPIDISTRA}

Lurida. One of the easiest decorative plants to grow. Will thrive almost anywhere incloors.

$$
5 \text { inch pots Each } \$ 2.00
$$

Lurida variegata. The dark green leaves are striped with white.

$$
5 \text { inch pots Each } 53.00
$$

\section{AUCUBA japonica}

A half hardy evergreen shrub with large, Laurel-like dark green foliage, frecly spotted with bright yellow. A most useful decorative plant for indoors in WVinter, or outdoors in Summer.

$$
4 \text { inch pots Doz. } \$ 4.59
$$

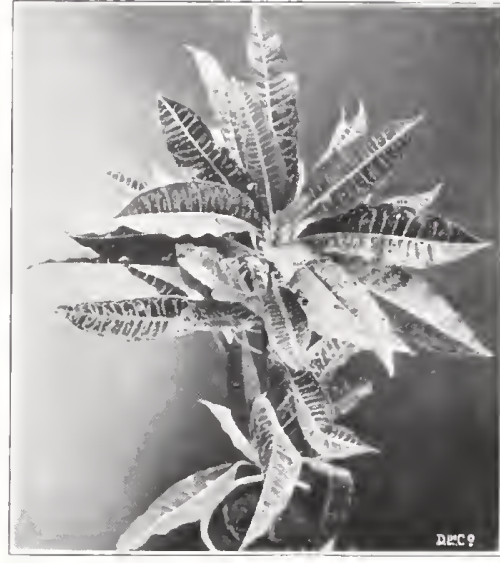

CROTONS

\section{CROTONS}

We offer a choice assortment embracins the best standard varieties as well as the most desirable recent introductions. Greatly varied in bright color combina tions. A good assortment of colors and types is assured.

$$
3 \text { inch pot plants Each } 81.25
$$

\section{CYPERUS alternifolius}

A small l'alm-like plant of the easiest culture. Will thrive in anv good soil, for indoors in Winter and outdoors in Summer. Must ahadys have plenty of ziater. I'sefu for in, or around pools, fountains, etc. It may be grown as a sub-aquatic.

\section{DRACAENAS}

Indivisa. This variety is used very extensively as a center plant for rases window boxes, Summer beds, etc. Long, narrow leaves. Each 50c. and \$1.00

Sanderiana. The variegated form having green foliage edged with a broad horder of creamy. white.

$$
3 \text { inch pot plants Each } 80.60
$$

\section{FERNS}

Adiantum farleyense gloriosa.

(The Glory Fern.) Easy growing form of that most beautiful of all Maidenhairs, Adiantum farleyense. Not suitable for dwelling house culture.

$$
\text { inch pols Each } \$ 1.2 .3
$$

Adiantum cuneatum. The well known, fine leaved Maidenhair fern so extensively used in connection with cut flowers. 3 inch pots Each 30c

Cibotium schiedei. (Mexican Tree Fern.) (One of the most desirable and valuable ferns for room decoration.

4 inch pot plants Each 1.25

Nephrolepis bostoniensis. (Boston Fern.) The original Bost on fern with long, graceful fronds. $\quad$ inch pots Each 75c. binch po's Eachsi.tis

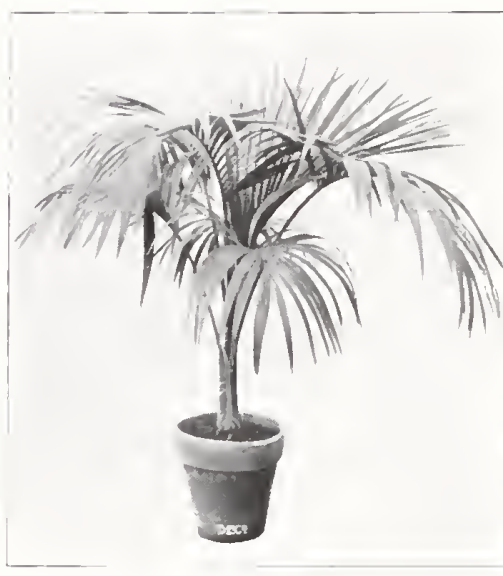

KENTIA BELMOREANA

\section{FICUS Rubber Plant}

Elastica. The well known Rubber plant. It inch pot plants Each $\mathbf{8 1 . 0 0}$

Repens. Trailing or creeping habit: small, dark green foliage, fine for corering the walls in greenhouses or for hanging baskets. Vice plants Each 50c.

\section{PANDANUS veitchi}

One of the finest decorative plants for house or conservatory. (iraceful foliage, striped white and green.

\section{PALMS}

Areca lutescens. One of the most graceful and beatiful Palms in cultivation. The foliage is bright glossy green with yellow stems.

3 inch pots (12 to 15 inches high) Each 7.jo. 4 inch pots (15to 15 inches high) Each $\$ 1.00$

Kentia beimoreana.

The harrliest of all P'alms.

$1 / l$ sizes at standard prices

Kentia forsteriana. All sizes at standurd prices

Phoenix roebeleni. $1 / 7$ sizes at standard price

\section{SANSEVIERIA}

Zeylanica laurenti. This varicty has a band of cream vellow about 1 , inch on each edge of the leaves; very decorative. 4 inch pots Each s1.50 6 inch pots Each -3.50

WE CAN SUPPLY VARIETIES OF STOVE OR ORNAMENTAL GREENHOUSE PLANTS NOT LISTED, ALSO ADDITIONAL SIZES OF THOSE LISTED -AT STANDARD PRICES 


\section{TRIVETT'S SUMMER BEDDING PLANTS}

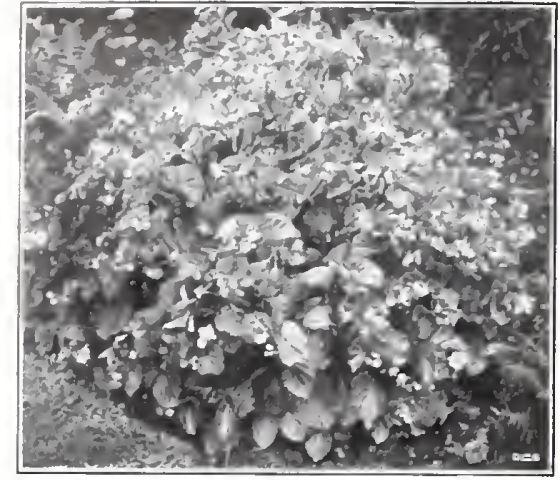

BEDDING BEGONIA-Erfordi

\section{AGERATUM}

Fraseri. The most popular sort: very compact, dwarf habit and free flowering. Fine Ageratum blue color.

$2 \frac{1}{4}$ inch pols $100 \$ 10.00$

New Improved Fraseri. A decided improvement over the original type.

\section{ALTERNANTHERAS}

Used principally for carpet bedding and edging; ornamental foliage about 4 inches high.

Aurea nana. Green and yellow.

Brilliantissima. Red with green, Each of the above,

$$
\begin{array}{lll}
\text { Rooted cuttings } & 100 & \$ 5.00 \\
\text { Pot grown plants } & 100 & 12.00
\end{array}
$$

ALYSSUM, Little Gem $21 / 4$ inch pots $100 \$ \$ .00$

ANTIRRHINUM (Snapdragon)

Giant Flowered Mixed.

ASTERS

$$
21 / 4 \text { inch pots } 100 \$ 15.00
$$

Giant Amer. Branching Mixed. 2/4 inch pots $100 \$ 15.00$

\section{BEGONIAS (Fibrous-rooted)}

Erfordi. Bright pink flowers which almost hide the foliage all Summer.

Luminosa. Coppery scarlet flowers and bronzy red foliage.

Chatelaine Supreme. A very choice pink sort.

Iny of the above,

$$
\text { Pot grown plants } 100 \$ 15.00
$$

\section{CANNAS}

King Humbert. Red with bronze foliage. 4 feet.

Hungaria. The best pink with green foliage.

The President. A fine green leaf, red llowered sort. $4^{1 / 2}$ feet.

Yellow King Humbert. Yellow flowers and green foliage. $41 / 2$ feet.

Fine pot grown plants $100 \$ 25.0025 \$ 6.50$

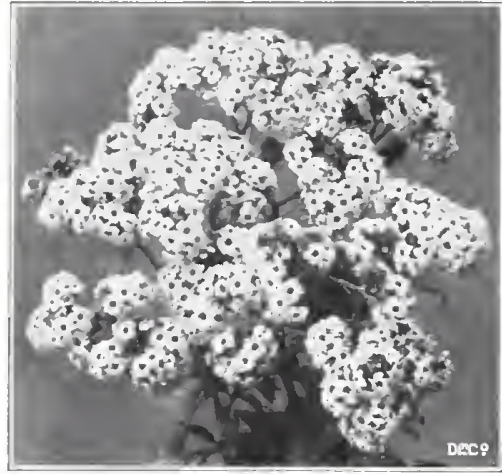

HELIOTROPE

\section{CENTAUREA gymnocarpa}

(Dusty-miller)

Silvery ornamental foliage, for edging. $21 / 4$ inch pots $100 \$ 12.00$

COLEUS, Mixed

$21 / 4$ inch pots $100 \$ 10.00 \quad 25 \$ 2.75$

CUPHEA (Cigarplant)

$21 / 4$ inch pots $100 \$ 10.00 \quad 25 \$ 2.75$

\section{ENGLISH IVY}

We can supply in different size pots at standard prices.

\section{GERANIUMS}

Alphonse Ricard. Double scarlet.

Poitevine. Very double salmon pink.

S. A. Nutt. Rich crimson. Double.

IVe can also supply other varieties.

$21 / 4$ inch pots $100 \$ 15.00 \quad 25 \$ 4.50$ inch pots $100 \$ 35.00 \quad 2510.00$

\section{HELICHRYSUM (Strawflower).} Mixed. 21/4 inch pots $100 \$ 12.00$ HELIOTROPE

Royal Fragrance. Truly a wonderful variety, dwarf grower about 10 inches high, bearing immense trusses of deep violet blue flowers. Delightfully sweet scented.

\section{LANTANAS}

We can supply in a number of named varieties and colors,

$2 \frac{1}{4}$ inch pots $100 \$ 15.00 \quad 25 \$ 4.00$

\section{LARKSPUR, Choice Mixed}

$21 / 4$ inch pots $100 \$ 15.00 \quad 25 \$ 1.00$

LOBELIA, Dwarf Blue

$21 / 4$ inch pots $100 \$ 12.00 \quad 25 \$ 3.25$

MARIGOLD

Giant African Mixed.

$21 / 4$ inch pots $100 \$ 12.00 \quad 25 \$ 3.25$

Legion of Honor. Dwarf, for edging. $21 / 4$ inch pots $100 \$ 12.00 \quad 25 \$ 3.25$

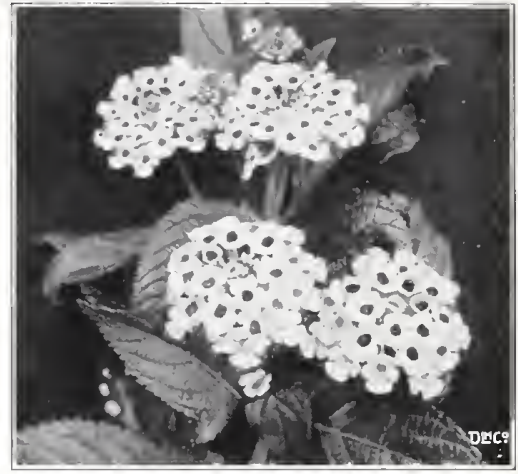

LANTANAS

MYOSOTIS (Forget-me-not)

Best blue. For bedding and edging. $21 / 4$ inch pots $100 \$ 12.00 \quad 25 \$ 3.50$

\section{PANSIES}

In separate colors and mixed at standard prices.

\section{PETUNIAS}

Single Mixed. All colors. $21 / 4$ inch pots $100 \$ 12.00 \quad 25 \$ 3.50$

PHLOX drummondi

Mixed. All colors.

$21 / 4$ inch pots $100 \$ 12.00 \quad 25 \$ 3.50$

\section{SALPIGLOSSIS}

Large Flowered Mixed.

$21 / 4$ inch pots $100 \$ 15.00 \quad 25 \$ 4.00$

SALVIA, Bonfire

Best dwarf, bushy red.

$21 / 4$ inch pots $100 \$ 12.00 \quad 25 \$ 3.25$

SCABIOUS, Mixed

$21 / 4$ inch pots $100 \$ 12.00 \quad 25 \$ 3.25$

STOCKS, Double Mixed

$21 / 4$ inch pots $100 \$ 18.00 \quad 25 \$ 4.75$

VERBENAS

Large Flowered Mixed.

$21 / 4$ inch pots $100 \$ 12.00 \quad 25 \$ 3.25$

\section{VINCA variegata}

A trailing ornamental plant used for hanging baskets, window boxes, etc. Green foliage mottled with white.

$21 / 4$ inch pots $100 \$ 12.00 \quad 25 \$ 3.25$ inch pots $100 \$ 25.00 \quad 25 \$ 6.50$

VIOLA, Jersey Gem

Soft violet blue flowers.

Pot growun $100 \$ 25.00 \quad 25 \$ 7.00$

ZINNIAS, Giant Flowered Mixed

$21 / 4$ inch pots $100 \$ 12.00 \quad 25 \$ 3.25$

\section{VEGETABLE PLANTS}

Ire can supply Vegetable plants such as Cabbage, Cauliflower, Eggplants,

Peppers, Celery, Tomatoes in season at standard prices 


\section{"Kest by test" PERENNIAL PLANTS Selected}

A brief, but carefully selected list of choice perennial plants. for the border and for cutting purposes

\section{ACONITUM}

Wilsoni. A tall variety from China with violet blue flowers. Blooms in Sept. Height 5 feet.

$100 \$ 50.00 \quad 25 \$ 13.00 \quad$ Doz. $\$ 6.75$

Sparks' Variety. Tall growing with branching spikes of blue flowers. The darkest Aconitum and has a long blooming period, July-Aug. Height 5 to 6 feet. $\begin{array}{lll}100 \$ 35.00 & 25 \$ 9.25 & \text { Doz. } \$ 5.00\end{array}$

\section{ANCHUSA}

Picotee. New! Blue and white. Height about 4 feet; a fine addition to the Anchusa family.

$100 \$ 50.00 \quad 25 \$ 13.00 \quad$ Doz. $\$ 6.75$

Myosotidiflora. Produces graceful panicles of bright blue flowers, resembling the Forget-me-not but with large, broad foliage. Blooms April-Mlay. Height 1 foot. $100 \$ 50.00 \quad 25 \$ 13.00 \quad$ Doz. $\$ 6.75$

\section{ANEMONE}

Japonica, Mount Rose. One of the finest free-flowering, double pink Anemones. Blooms Sept.-Oct. Height 2 feet.

$100 \$ 30.00 \quad 25 \$ 8.00 \quad$ Doz. $\$ 4.50$

Japonica, Richard Arends. New! Large double white tinted pink. Blooms Sept.-Oct. Height 3 feet.

$100 \$ 50.00 \quad 25 \$ 13.00 \quad$ Doz. $\$ 6.75$

ANTHEMIS

Perry's Variety. A new hardy perennial of sterling merit. A wonderful improvement over the well-known Golden Marguerite. Bright golden yellow flower from June to October. Silver medal and first class certificate at Elstree and bronze medal at Birmingham England. 21/ in. pots.

$$
100 \$ 75.00 \quad 25 \$ 20.00
$$

\section{ARMERIA}

Cephalotes, Bee's Ruby. Fine improved variety, large flower heads of brilliant pink on long stems. Blooms June-July. Height $11 / 2$ feet.

$100 \$ 75.00 \quad 25 \$ 19.50 \quad$ Doz. $\$ 10.00$

\section{ARTEMISIA}

Silver King. New! A plant with finely cut leaves, growing about 3 feet high. The dried leaves are used for decorating purposes.

$$
100 \$ 30.00 \quad 25 \$ 8.00 \quad \text { Doz. } \$ 4.50
$$

\section{BUDDLEIA superba}

An exceptionally beautiful variety. The flower spikes are much longer than the ordinary variety and also very full and uniform. Distinct deep blue lilac flowers. $100 \$ 90.00 \quad 25 \$ 25.00 \quad$ Doz. $\$ 14.00$

\section{CAMPANULA persicifolia}

Telham Beauty. One of the best introductions of recent years; large, bellshaped blue flowers borne on plants about 21/2 feet high. Excellent for cutting and borders. Blooms June-July.

$$
100 \$ 50.00 \quad 25 \$ 13.00 \quad \text { Doz. } \$ 6.75
$$

Not listed in our General Catalogue)

\section{CENTAUREA dealbata}

Beautiful pink flowers with white center. Plants are of good, compact habit. Bloonrs July-Aug. Height $1 \frac{1}{2}$ feet.

$$
100 \$ 25.00 \quad 25 \$ 6.75
$$

Doz. $\$ 3.75$

\section{CHRYSANTHEMUMS}

See General Catalogue.

\section{CIMICIFUGA racemosa}

Simplex, One of the most beautiful attractions in the perennial border. The dense spikes of feathery white flowers are borne on tall, graceful stems, 3 to 4 feet

high. Excellent for cutting and an ideal flower for vases.

$$
100 \$ 65.00 \quad 25 \$ 17.00 \quad \text { Doz. } \$ 9.00
$$

\section{DELPHINIUM}

Wrexham or Hollyhock. These remarkable new Delphiniums originated by Watkin Sanuel, Wrexham, England, are of unusual size and the stalks are much taller than other Delphiniums. We offer field grown plants of very choice mixture at a special price.

$100 \$ 75.00 \quad 25 \$ 20.00 \quad$ Doz. $\$ 12.00$

\section{DIGITALIS}

Giant Shirley. This is a magnificent strain attaining a height of 5 to 7 feet with flower spikes 4 feet long. Colors range from white to deepest rose marked with crimson and maroon. (Mixture only) $100 \$ 30.00 \quad 25 \$ 8.00 \quad$ Doz. $\$ 4.50$

\section{DORONICUM}

Plantagineum excelsum. Beautifu. golden vellow, Gerbera-like flowers on excellent long stems for cutting. Blooms early Spring. Height $1 \frac{1}{2}$ to 2 feet.

$100 \$ 35.00 \quad 25 \$ 10.00 \quad$ Doz. $\$ 5.50$

\section{EUPATORIUM}

Coelestinum. Splendid hardy plant for cutting and borders, producing Ageratum-like flowers of light blue color. Blooms Aug. to Oct. Height 2 feet.

$100 \$ 30.00 \quad 25 \$ 8.00 \quad$ Doz. $\$ 4.50$

\section{GAILLARDIA Portola}

New! A vigorous grower reaching $21 / 2$ to 3 feet with beautiful foliage. The flowers are brilliant coppery scarlet margined with golden yellow. A wonderful improvement over the ordinary Gaillardia. Bloons all Summer.

$$
100 \$ 50.00 \quad 25 \$ 13.00 \quad \text { Doz. } \$ 6.75
$$

\section{G YPSOPHILA}

Bristol Fairy. Of recent introduction, this double flowering Gypsophila has larger flowers than the old variety, makes an excellent cut flower. Blooms Summer. Height 2 to 3 feet. Grafted stock out of pots. $100 \$ 95.00 \quad 25 \$ 25.00 \quad$ Doz $\$ 15.00$
HEATHER Erica)

Vulgaris. (Scotch Heather) This is the true rosy purple Scotch Heather.

$100 \$ 50.00 \quad 25 \$ 13.00 \quad$ Doz. $\$ 6.75$

Vulgaris alba. White Scotch Heather $100 \$ 50.00 \quad 25 \$ 13.00 \quad$ Doz. $\$ 6.75$ IRIS

See General Catalogue.

MONARDA didyma

Salmonea. Large heads of delicate salmon pink; fine for perennial borders. Blooms June-Aug. 3 feet. $100 \$ 30.00 \quad 25 \$ 8.00$

PEONIES

\section{See General Catalogue.}

\section{PHYSOSTEGIA}

Virginiana grandiflora. An outstanding perennial for the border and cutting with bright pink flowers which are borne on stiff stems. Height 1 foot. Blooms Aug.-Sept.

$$
100 \$ 35.00
$$

\section{SALVIA}

Azurea grandiflora. (Pitheri). The flowers are deep indigo blue and are borne in great profusion on long, slender stems. 3 to 4 feet high, very hardy. Bloons from Aug. to Oct. Splendid for cutting.

$100 \$ 35.00 \quad 25 \$ 9.25 \quad$ Doz. 85.00

\section{SIDALCEA}

Rose Queen. Beautiful rose pink flowers, very distinct. Blooms July-Aug. Height 2 to 3 feet.

$100 \$ 30.00 \quad 25 \$ 8.00 \quad$ Doz. $\$ 4.50$

\section{TRITOMA pfitzeri}

The freest flowering of all; orange scarlet shaded to salmon rose at edge. Invaluable for cutting. The plants should be well protected during Winter. Blooms Aug. to Sept. Height 2 to 3 feet.

$$
100 \$ 30.00 \quad 25 \$ 8.00 \quad \text { Doz. } \$ 4.50
$$

\section{VERONICA}

Longifolia subsessilis. This is one of the most beautiful of herbaceous plants throwing up branching blue spikes of flowers; very attractive. Blooms until Fall. Height 2 feet.
$100 \$ 30.00$
$25 \$ 5.00$
Doz. $\$ 4.50$

\section{VIOLA}

Seattle Gem. Developed from a sport of Viola Jerser Gem. The blooms are a beautiful Primrose-yellow, frilled as in Jersey Gem and borne on exceptionally long stems. It does not set seed and is a mass of bloom from Spring onwards. 21/4 in. pots. $\quad 100 \$ 50.00 \quad 25 \$ 16.00$

WE CAN SUPPLY A FULL LINE OF HARDY PERENNIAL PLANTS

Especially grown by perennial plant specialists

At Regular Standard Prices 


\section{A SELECTION OF EASILY GROWN ROCK PLANTS}

The following list of rock plants comprises only those of easy culture and which have been suggested

by a veteran rock gardener as suitable for average use by the average rock garden enthusiast.

$$
\text { V'ariely }
$$

ACHILLEA tomentosa.

ALYSSUM saxatile compactum

ANEMONE pulsatilla sylvestris.

ARABIS alpina.

ARENARIA montana

ARMERIA laucheana.

ASTER alpinus

AUBRIETIA deltoidea

CAMPANULA carpatica

carpatica alba

muralis.

rotundifolia

CERASTIUM tomentosum

DIANTHUS caesius deItoides.

DICENTRA eximia

GERANIUM sanguineum

G YPSOPHILA cerastioides

HELIANTHEMUM aureum

Ball of Fire

Bride

HEPATICA triloba

HYPERICUM repens

IBERIS Little Gem

IRIS cristata.

pumila

$$
\text { Verna. }
$$

LEONTOPODIUM alpinum

MERTENSIA virginica.

MYOSOTIS dissitiflora

Ruth Fischer

NIEREMBERGIA rivularis

PAPAVER alpinum.

nudicaule. .

PHLOX amoena.

divaricata

divaricata alba.

ovata. .

subulata

POLEMONIUM reptans

PRIMULA acaulis

japonica

auricula

beesiana

polyantha

pulverulenta

veris

SANTOLINA chamaecyparissus

SAPONARIA ocymoides.

SAXIFRAGA cochlearis

dicepiens.

crassifolia

SEDUM acre

album.

hispanicum

spectabile, Brilliant

SEMPERVIVUM alberti

californicum

globiferum

SILENE alpestris. .

THYMUS citriodorus. serpyllum serpyllum coccineus

TUNICA saxifraga.

VERONICA incana.

Iongifolia subsessilis

repens.

spicata.

spicata alba

spicata erica.

VIOLA, Admiration

Jersey Gem. .

Lutea Splendens

Snow Queen.

$$
\text { Color }
$$

Yellow orange

Yellow orange

Blue purple

IVhite

IVhite

II'hite

Red.

Blue

Blue

Blue

II'hite

Blue

Blue.

White

Pink.

Pink.

Pink.

Red.

Lilac and white

yellow orange.

Red

White

Blue.

Vellow.

I'hite

Light blue

Purple.

Blue.

White

Blue.

Light blue

Blue.

White.

Yellow

Assorted

Pink.

Blue.

White

Red

Pink.

Blue.

Yellow.

Red. .

Many shades.

Purple.

Yellow orange

Violet.

Yellow orange.

Yellow.

Red.

White

Crimson

Pink.

Yellow

White

l'ink

Red

Red

Red.

Yellow

White.

Yellow

White

Red.

pink

Blue

Blue

Blue

Blue.

II'hite

Pink

Blue

Blue.

Yellow

White.
Height

. $1 \mathrm{ft}$

$1 \mathrm{ft} \ldots \ldots$. . June

April-May

$1 \mathrm{ft} \ldots \ldots \ldots$...... April-May

$11 / 2 \mathrm{ft} \ldots \ldots \ldots$ April-May

5 in ......... April-Nay

$t$ in . . . . . . April-May

6 in . . . . . . June-Augus

Sin.... Mlay-June

6 in ........ April-Mlay

6 in . . . . . . July-Aug.

6 in .... July-Aug.

$t$ in.......... May-June

$1 \mathrm{ft} \ldots \ldots \ldots$. . . June-Aug.

6 in ..... May-June

5 in . . . . . May-July

$S$ in .......... May-June

$1 \mathrm{ft}$..... June-Aug.

15 in. . . . . . Nlay-Aug.

4 in......... July-Aug.

S-10 in ...... June-July

8-10 in ......... June-July

\$-10 in . . . . June-July

5 in........... April-May

5 in . . . . . . . . July

6 in . . . . April

5 in.......... April-May

$1-2 \mathrm{ft} . . . \ldots \ldots$. May

4 in. . . . . . Mlay

5 in......... June-July

$11 / 2 \mathrm{ft} \ldots . . \ldots$. May-June

$8-10$ in ........ May-June

$8-10$ in ....... May-June

8 in .......... June-Aug.

6 in . . . . June-August

$1 \mathrm{ft} . .$. May-Aug.

1-6 in......... April-May

10 in......... May

10 in ..... May

$1-11 / 2 \mathrm{ft} \ldots \ldots \ldots$ June-July

$3-6$ in . . . . . April-Nlay

\$-12 in ....... April-May

6-9 in . . . . . . April-May

9 in . . . . . . . June

6-8 in.... May-June

$2 \mathrm{ft} . . . \ldots \ldots$ May-June

6-12 in .... May-June

$11 / 2-21 / 2 \mathrm{ft} \ldots . .$. May-July

$6-9$ in ........ April-May

$11 / 2 \mathrm{ft} \ldots \ldots \ldots$ Evergreen

$1 \mathrm{ft}$ May-July

4 in.......... May-June

4 in . . . . . . May-June

12 in . April-June

3 in........... May-June

3 in. . . . . May-July

4 in ......... June-July

6 in .July-Sept.

8 in . . . . . . . Sept.-Oct.

$1 \mathrm{ft}$. . . . . . .

$1 \mathrm{ft}$ Sept.Oct.

t-6 in......... Mlay-June

$t$ in ........ June-July

$3-4$ in ........ June-July

$3-5$ in . . . . . . J June-July

6 in . . . . July-Sept.

$1 \mathrm{ft} \ldots \ldots$ July-Aug.

$2 \mathrm{ft} \ldots \ldots$ Aug.-Sept.

4 in... May

$11 / 2 \mathrm{ft} \ldots \ldots \ldots$ June-July

$11 / 2 \mathrm{ft} \ldots \ldots \ldots$ June-July

$11 / 2 \mathrm{ft} \ldots$ June-July

$1 / 2-1 \mathrm{ft} \ldots . . . . .2$ May-Aug.

6 in........ May-Nov.

$1 / 2-1 \mathrm{ft} \ldots \ldots .$. Мay-Aug.

1-11/2 ft........ May-Aug.

All Plants: 3 for $\$ 1.00,10$ for $\$ 3.00,25$ for $\$ 7.00$. Not less than 3 plants of 1 variety sold 


\section{EVERGREEN AND FLOWERING SHRUBS FOR THE ROCK GARDEN}

\section{ABELIA}

Chinensis (rupestris). Ilybrid Abelia. The graceful, arching stems are clothed with clark, glossy, nearly persistent leaves; white flowers tinged with pink, about an inch long, borne in profuse clusters from Summer until frost. Strong, pot grown plants.

\section{ACER}

Palmatum atropurpureum (Bloodleaved Japanese Maple). A very conspicuous, medium-sized bush or tree with blood red foliage.

$$
8 \text { to } 10 \mathrm{in} \text { Each } \$ 2.50
$$

\section{AMPELOPSIS}

Tricuspidata lowi lowi) (Nerv Japanese (vy). Like A. veitchi, it clings to the smoothest surface. Brilliant crimson in Autumn. Pot-grown plants Each \$1.25

\section{AZALEA}

Amoena. Flowers are bright rosy purple and are produced in a solid mass in May. 10 to 12 in. Each $\$ 2.50$ 12 to 15 in. Each $\$ 2.75$

Bengiri. Evergreen leaves, rather narrow and stightly concave: nice, compact habit. Flower deep bright red, almost scarlet. sito $10 \mathrm{in}$ Each $\$ 1.75$ 10 to 12 in. Each $\$ 2.50$

Hakalata-shiro. Flowers single, snow white, 1 inch in diameter. Dark green, narrow leaves. 10 to 12 in. Each $\$ 2.50$

Hinodegiri. A bright scarlet form of the well known and charming A. amoena, but far surpassing it in brilliancy and beauty; a profuse bloomer.

$$
\begin{aligned}
& 10 \text { to } 12 \text { in. Each } \$ 2.00 \\
& 12 \text { to } 15 \text { in. Each } \$ 3.75
\end{aligned}
$$

Indica alba (ledifolia alba). Pure white flowers; luxuriant grower and profuse bloomer.

$$
\begin{aligned}
& 10 \text { to } 12 \text { in. Each } \$ 1.50 \\
& 12 \text { to } 15 \mathrm{in.} \quad \text { Each } \$ 2.00
\end{aligned}
$$

Kaempferi. Large, beautiful, fire red flowers. Being absolutely hardy it is a fine variety for our chimate. Grows tall and bushy.

$$
\begin{aligned}
& 12 \text { to } 15 \text { in. high Each } \$ 2.00 \\
& 15 \text { to } 15 \text { in. high Each } \$ 2.75
\end{aligned}
$$

Maxwelli. Large, single, carmine red Hlowers 2 inches in diameter. Low and broad. lery hardy.

$$
\begin{aligned}
& 12 \text { to } 15 \text { in. Each } \$ 2.50 \\
& 15 \text { to } 15 \text { in. Each } \$ 3.00
\end{aligned}
$$

Mollis. They are quite hardy in this latitude and thrive under ordinary garden treatment, but to best in a protected spot, where partially shaded. Mixed colors. 12 to 15 in. Each $\$ 2.50$ 15 to 18 in. Each $\$ 3.50$

Rosaeflora (balsaminaeflora). Very compact and dwarf grower. Double light orange Howers.

12 to 14 in. diam. specimen Each $\$ 7.50$ 14 to 16 in. diam. specimen Each $\$ 10.00$

\section{BERBERIS}

Julianae. Beautiful evergreen variety; very hardy; stays perfectly green during the Winter. Excellent.

10 to $12 \mathrm{in.}$, pot grown Each 81.50

Verruculosa. Attractive evergreen of medium grow th. Shiny foliage, distinctly blue underneath. Forms a compact, low bush Pot grown plants Each $\$ 1.00$

\section{COTONEASTER}

Horizontalis. Curious, twarf shrub of trailing habit. Fine for rockeries. It is covered with brilliant red berries in Autumu and Vinter. The foliage turns to soft tints of red and bronze before falling. Pot grown plants Each $\$ 1.00$

Microphylla. A real prostrate shrub, with small, shiny leaves, longer than those of the former variety and having long hairs beneath. Pretty white flowers are followed by searlet berries; very showy. Pot grown plants Each $\$ 1.00$

\section{DAPHNE}

Cneorum (Garland Flower). A trailing evergreen plant, with narrow, glossy green leaves; flowers fragrant, bright pink, in round clusters at tips of branches, appearing in May and August. All pot grown plants. 3 to 5 in. pots Each 75 c. to 81.50

\section{EUONYMUS}

Radicans minimus kewensis). A rare little trailing plant with very smakl, round leaves, light green with whitish veins. Always remains close to the ground. lot grown plants Each 75c.

\section{JASMINUM}

Nudiflorum (Naked Flowering Jessamine). Rich golden yellow flowers. Blooms early. Pot grown plants Each $\$ 1.00$

\section{JUNIPERUS}

Depressa (canadensis). Forms broad patches with stems ascending from a procumbent base, rarely exceeding '2 feet in height. Is a rockery plant it cannot be surpassed.

$$
12 \text { to } 15 \mathrm{in.} \text { diam. Each } \$ 1.50
$$

Depressa aurea. Low growing. Tips of branchlets golden yellow

10) to $12 \mathrm{in}$. diam. Each 81.50

Excelsa stricta. Very symmetrical, conical outline. Foliage glaucous and arranged around the branches in threes, dense and prickly .. \& to $10 \mathrm{in}$. Each $\$ 1.50$

Horizontalis (prostrata). Dull green leaves. Grows rapidly and makes a very pleasing effect when planted on terraces. 15 to 18 in. diam. Each $\$ 1.55$

Squamata. Prostrate variety with thick branchlets, ascending at the apex; foliage crowded, grayish or bluish green; bluish black fruit. 12 to 18 in. diam. Each 82.25

\section{LEUCOTHOE}

Catesbaei (Andromeda). A valuable shrub for planting under trees, on the margins of noodland drives, and in other shady. positions. Flowers are fine white and are borne in long, pendulous racemes, with a characteristic fragrance. The shining foliage is evergreen. 12 to $1 \mathrm{~h}$ in. Each $\$ 1.75$

\section{PICEA}

Glauca conica (Drearf 1lberta Spruce) Very rare. I charming, compact, coneshaped evergreen with very dense foliage and of slow growth. Invaluable for formal effects and rock gardens.

$$
10 \text { to } 12 \text { in. Each } 83.75
$$

\section{PIERIS}

$$
12 \text { to } 15 \text { in. Each } 55.00
$$

Japonica (Andromeda japonica). Leaves toothed, crowded at the ends of the shoots. l'anicles of buds clull red, opening white in spring. Foliage spotted bronzy red in IVinter. $\quad 12$ to $15 \mathrm{in}$ Each $\$ 200$

\section{PINUS}

Mughus (Dwarf Mugho Pine). Distinct of compact and prostrate habit, with the tips of branches ascending; the leaves are twisted slightly.

10 to 12 in. Each $\$ 2.50$ 12 to $15 \mathrm{in.}$ Each $\$ 3.00$

\section{RETINOSPORA}

Filifera aurea. Nost attractive, bright golden form, of similar habit to its parent. 12 to 15 in. Each $\$ 2.50$

\section{RHODODENDRON}

Boule de Neige (Dwarf). White. 15 to 1 in. diam. Each 85.00

Carolinianum album (Ithite Carolina Rhododendron). Small, narrow, dark green leaves. White flowers in Mlay.

$$
12 \text { to } 15 \mathrm{in.} \text { Each } \$ 3.00
$$

Micranthum (Manchurian Rhododendron). Very distinct species. Clusters of small white flowers. l'erfectly hardy.

\section{SCIADOPITYS} 15 in. Each $\$ 2.50$

Verticillata (Japanese L'mbrella Pine). Viry long leaves, much wider and thicker than those of other conifers, shining green above and a line of white underneath; they: are deeply grooved on both sides and are borne at the ends of the annual shoots.

\section{TAXUS} 15 to 18 in. Each $\$ 7.50$

Repandens. This is the hardiest of atl prostrate varieties, and will grow in almost any position. The slender, pointed leaves gently curve upward, and are of a lustrous green. 12 to $15 \mathrm{ill}$. Each $\$ 2.50$ Nana brevifolia). Really an exceltent Yew, with fine, spreading branches and rich, deep green, short leaves.

\section{THUJA}

$$
12 \text { to } 15 \text { in. Each } \$ 3.00
$$

Little Gem. Very dwarf; grows broader than high; the flat branchlets are of a satisfactory green. 


\section{ORNAMENTAL EVERGREENS AND CONIFERS}

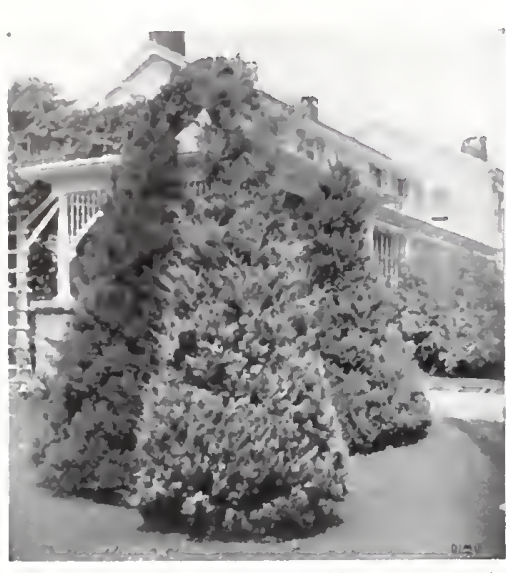

Group planting of ${ }_{4}$ RETINOSPORA

\section{BOXWOOD (Buxus)}

Sempervirens (Common Tree Box). A large shrub with thick, leathery dark green leaves. Bears shearing well and can be shaped in any form desired. Bush Form. In various sizes.

Each $\$ 2.00$ to $\$ 15.00$ Pyramids. In various sizes.

Each $\$ 7.00$ to $\$ 20.00$

\section{BOXWOOD EDGING}

Dwarf Box (suffruticosa). The well known Box used for edging, and invaluable for that purpose.

$$
4 \text { to } 6 \text { in. } 100 \$ 25.00
$$

\section{JUNIPERUS (Juniper)}

Excelsa stricta. Foliage glaucous and arranged around the branches in threes, dense and prickly.

$1 \mathrm{ft}$. Each $\$ 2.50 \quad 11 / 2 \mathrm{ft}$. Each $\$ 3.00$ $2 \mathrm{ft}$. Each $\$ 1.00 \quad 2 \frac{1}{2} \mathrm{ft}$. Each $\$ 5.00$

Hibernica (Irish Juniper). A distinct and beautiful variety, of erect, dense, conical outline.

12 in. Each $\$ 1.50$ 1s in. Each \$2.25

Pfitzeriana. Very distinct, being of striking, graceful habit; the color bright silvery green; perfectly hardy.

$$
\begin{array}{ll}
18 \text { to } 21 \mathrm{in} . & \text { Each } \$ 3.50 \\
2 \text { to } 21 / 2 \mathrm{ft} . & \text { Each } \$ 5.00
\end{array}
$$

Sabina (Compact Savin Juniper). Low, trailing habit and fine for massing.

$12 \mathrm{in.}$ Each $\$ 2.00 \quad 18$ in. Each $\$ 4.00$

Virginiana (Red Cedar). Of medium, compact growth.

$3 \mathrm{ft}$ Each $\$ 3.50 \quad 4 \mathrm{ft}$. Each $\$ 6.00$ $5 \mathrm{ft}$. Each $10.00 \quad 6 \mathrm{ft}$. Each 12.00

Virginiana glauca (Silvery Red Cedar). $2 \mathrm{ft}$. Each $\$ 4.00 \quad 3 \mathrm{ft}$. Each $\$ 7.00$

\section{KALMIA}

Latifolia (Mountain-laurel or Calico Bush). 1 to $11 / 2 \mathrm{ft}$., nursery grown Each $\$ 2.50$ $11 / 2$ to $2 \mathrm{ft}$, nursery grown Each $\$ 5.00$ 2 to $3 \mathrm{ft}$., nursery grown Each $\$ 6.00$ l'rices for carload lots of collected stock on application.

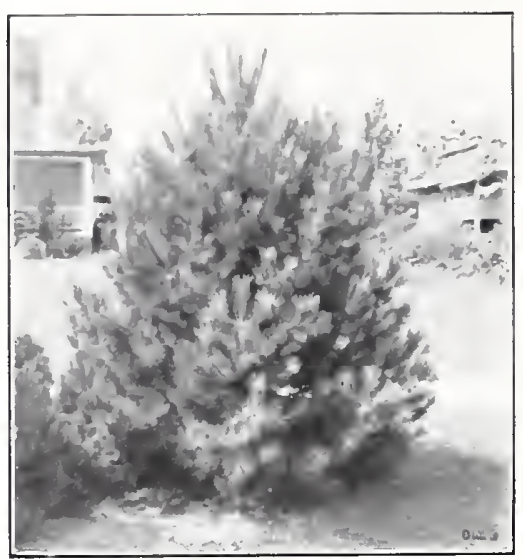

PINUS austriaca (Austrian Pine)

\section{PICEA}

Excelsa (Nonway Spruce). Leaves dark green, very handsome; of pyramidal, lofty appearance.

$$
\begin{aligned}
11 / 2 \text { to } 2 \mathrm{ft} & \text { Each } \$ 2.00 \\
2 \text { to } 3 \mathrm{ft} & \text { Each } \$ 4.00 \\
3 \text { to } 4 \mathrm{ft} . & \text { Each } \$ 6.00
\end{aligned}
$$

Pungens (Colorado Spruce). Leaves bluish. 18 to 24 in. Each $\$ 5.00$

\section{PINUS} 2 to $3 \mathrm{ft}$. Each $\$ 7.50$

Austriaca (Austrian Pine). A robust, stately tree of rapid growth and very hardy. $2 \mathrm{ft}$. Each $\$ 3.00 \quad 21 / 2 \mathrm{ft}$. Each $\$ 4.00$ Mughus (Dwarf Mugho Pine).

12 to 18 in. diam. Each $\$ 3.50$ $11 / 2$ to $2 \mathrm{ft}$. diam. Each $\$ 5.00$

Strobus (White Pine). One of the best native Pines; pale light green foliage. 2 to $3 \mathrm{ft}$. Each $\$ 3.50$ 3 to $4 \mathrm{ft}$. Each $\$ 5.00$ Sylvestris (Scotch Pine). Of rapid growth, with strong branches and short, stiff, bluish green foliage.

$2 \mathrm{ft}$. Each $\$ 3.00$

$3 \mathrm{ft}$. Each $\$ 4.50$

\section{RETINOSPORA}

Filifera (Japanese Cedar). Threadbranched, drooping branches, bright green; very pretty.

$1 \frac{1}{2} \mathrm{ft} . \$ 3.50$ each $\quad 2 \mathrm{ft} . \quad \$ 5.00$ each

Filifera aurea. Golden; most attractive. 18 in., bushy shaped. Each $\$ 4.00$

Obtusa. Graceful tree, foliage bright clear green.

$2 \mathrm{ft}$. Each $\$ 4.00 \quad 3 \mathrm{ft}$. Each $\$ 7.00$

Pisifera (Sawara Cypress). Branches horizontal, with leaves feathery green above, whitish lines beneath.

$11 / 2 \mathrm{ft}$. Each $\$ 3.50 \quad 2 \mathrm{ft}$. Each $\$ 5.00$ $3 \mathrm{ft}$. Each $\$ 7.50$

Pisifera aurea. Golden feathery foliage. $11 / 2 \mathrm{ft}$. Each $\$ 3.50 \quad 2 \mathrm{ft}$. Each $\$ 5.00$ Plumosa. Graceful habit.

$11 / 2 \mathrm{ft}$. Each $\$ 3.00 \quad 2 \mathrm{ft}$. Each $\$ 4.00$ $21 / 2 \mathrm{ft}$. Each $\$ 5.00 \quad 3 \mathrm{ft}$. Each $\$ 7.00$

Plumosa aurea. Golden foliage.

$11 / 2 \mathrm{ft}$. Each $\$ 3.002$ to $3 \mathrm{ft}$. Each $\$ 5.00$

Squarrosa veitchi. Light bluish green

$11 / 2 \mathrm{ft}$. Each $\$ 3.00 \quad 2 \mathrm{ft}$. Each $\$ 5.00$

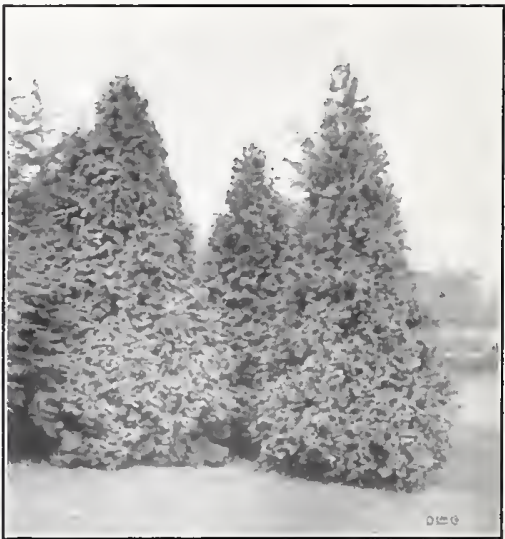

THUJA occidentalis

(Common American Arborvitae)

\section{RHODODENDRONS}

Hardy Hybrid Varieties. Handsome grouping and border effects can be created by using these charming hybrids.

18 to 24 in. Each $\$ 7.50$ 24 to 30 in. Each $\$ 10.00$

30 to 36 in. Each $\$ 12.00$

Maximum (Great Laurel). Is admirably adapted to massing, will thrive in shady or exposed positions, and is perfectly hardy. Nursery grown.

$\begin{aligned} 2 \text { to } 21 / 2 \mathrm{ft} . & \text { Each } \$ 5.00 \\ 21 / 2 \text { to } 3 \mathrm{ft} . & \text { Each } \$ 7.00 \\ 3 \text { to } 4 \mathrm{ft} . & \text { Each } \$ 9.00\end{aligned}$

Prices for carload lots of collected stock on application.

\section{TAXUS}

Baccata repandens (Yew). This is the hardiest of all prostrate varieties and will grow in almost any position. It is excellent for hedging, grouping and covering banks. $1 \frac{1}{2}$ to $2 \mathrm{ft}$. diam. Each $\$ 4.00$

Cuspidata. Spreading form. 12 to 18 in. high Each $\$ 3.50$ $1 \mathrm{~s}$ to $24 \mathrm{in}$. high Each $\$ 5.00$ 2 to $21 / 2 \mathrm{ft}$. high Each $\$ 7.50$ Cuspidata nana brevifolia. Really an excellent Yew, with fine, spreading branches and rich deep green, short leaves. Highly recommended.

$15 \mathrm{in}$. Each $\$ 3.50 \quad 11 / 2 \mathrm{ft}$. Each $\$ 6.00$

THUJA $2 \mathrm{ft}$. Each $\$ 8.00$

Pyramidalis (Pyramidal Arborvitae). A most valuable, upright evergreen, of dense, compact habit. Foliage light green.

$2 \frac{1}{2} \mathrm{ft}$. Each $\$ 4.003$ to $4 \mathrm{ft}$. Each $\$ 7.00$ 4 to $5 \mathrm{ft}$. Each $\$ 10.00$

Occidentalis (Common American Arborvitae). 2 to $3 \mathrm{ft}$. Each \$3.50 3 to $4 \mathrm{ft}$. Each $\$ 5.00$ 4 to $5 \mathrm{ft}$. Each $\$ 7.50$

Wareana occidentalis sibirica (Siberian A rborvitae). Large, bold, glaucous green foliage.

$2 \mathrm{ft}$. Each $\$ 3.50 \quad 21 / 2 \mathrm{ft}$. Each $\$ 5.00$

\section{TSUGA}

Canadensis (Common IIemlock). One of the most handsome and graceful evergreens. 18 to 24 in. Each $\$ 3.50$ 2 to $3 \mathrm{ft}$. Each $\$ 5.00$ 3 to $4 \mathrm{ft}$. Each $\$ 7.50$ 


\section{TRIVETT'S NEW AND IMPROVED VEGETABLES FOR 1931}

The following varieties are not listed in our General Catalogue

\section{BEANS}

The Wonder. An English novelty which we consider to be the finest early long podded variety yet introduced. It is an immense cropper, producing fine, long pods equaling those of Masterpiece, but in greater profusion. Especially good for greenhouse culture. Hward of Merit, R. H. S.

4qts. $\rightarrow 1 \mathrm{bs}$.) $\$ 5.75$ Qt. (2 lbs. $\$ 1.50$ Pt. (1 lib.) $80 \mathrm{c}$.

Trivett's Ideal Pole. The earliest and most productive green podded Pole Bean, as early as many of the bush sorts. Produces an immense crop of handsome pods in clusters. The tender, green pods are long, slender, round in shape and stringless when young. Without question this is the finest green podded Pole Bean we can offer.

4 qts. (๖lbs.) $\$ 5.50 \quad$ Qt. (21bs.) $\$ 1.50 \quad$ Pt. (1 lb.) 80c.

Trivett's Early Valentine. Greatly improved Red Valentine, which will eventually supplant the old type. This variety is extra early and stringless. Highly recommended.

4 qts. ( $\triangle 1 \mathrm{bs}) \$$.$5.50 \quad (2t. (21b.) \$ 1.50 \quad$ Pt. (1 lb) $80 \mathrm{c}$.

\section{BEET}

Oval Gem. This new Beet is oval or egg-shaped, with bronzy green foliage and just the right size for the table. However the real merit of this variety is its splendid quality, dark red, slightly ringed. When cooked the rings disappear, turning the entire Beet to the color of a glowing ruby, melting tenderness, sweet flavor and entire absence of fiber.

$$
1 / 1 \mathrm{lb} . \$ 2.50 \quad \text { Oz. } 75 \mathrm{c} \text {. }
$$

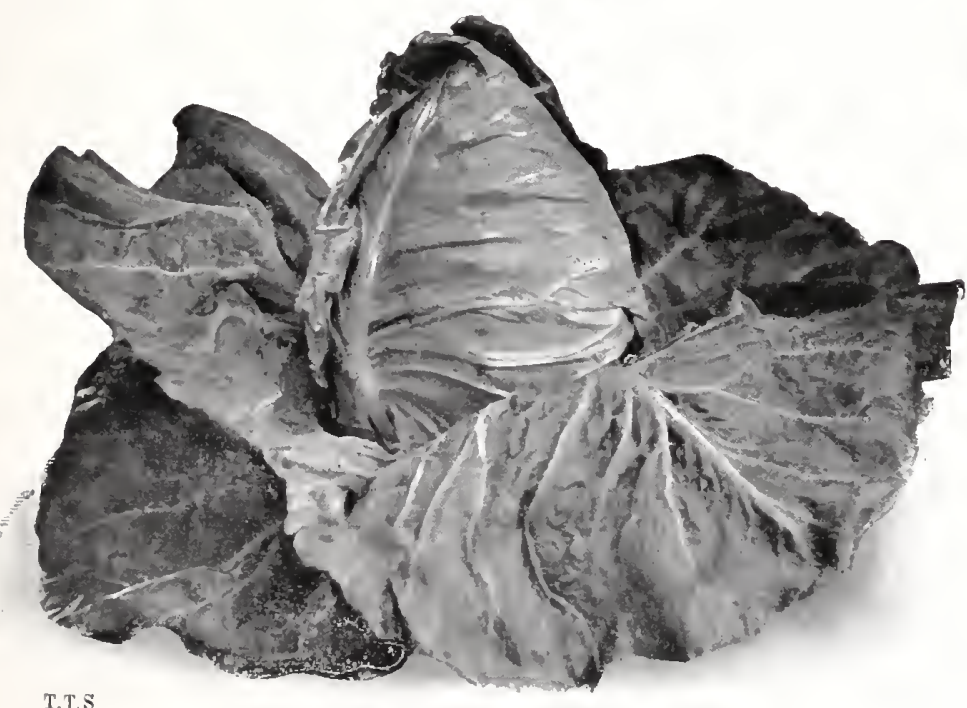

T.T.S

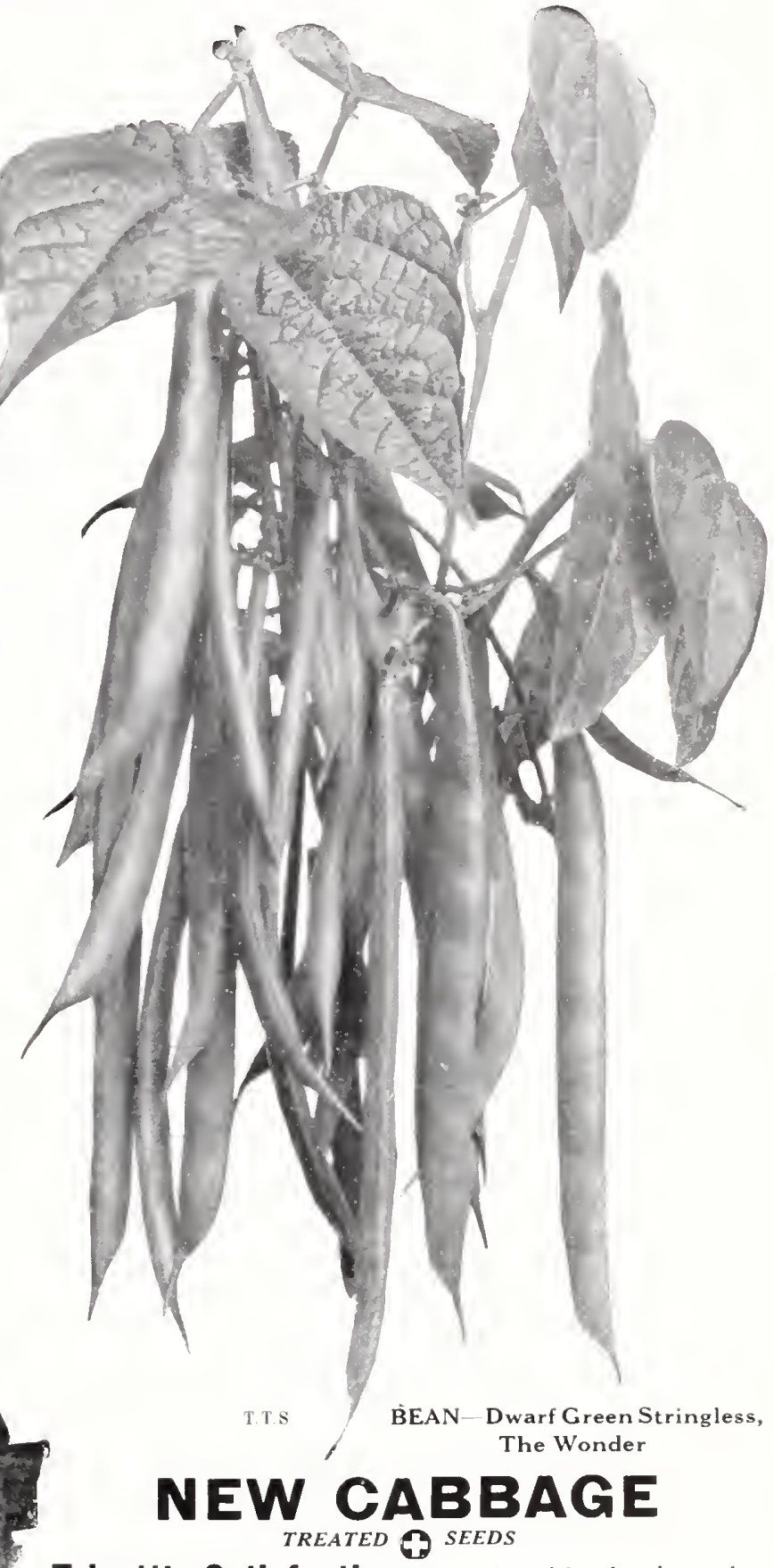

Trivett's Satisfaction. A splendid selection, the pointed heads are firm and solid, tender and delicate in flavor. The habit is dwarf with few outer leaves, thus eliminating waste. Strongly recommended. (Illustrated.)

Oz. $\$ 1.50 \quad 1 / 2$ oz. $80 \mathrm{c} .1 / 4 \mathrm{oz} .45 \mathrm{c}$. Pkt. 30c.

DON'T STICK TO THE OLD VARIETIES

They eventually "run out"- become exhausted GROW THE NEWER AND BETTER SORTS 


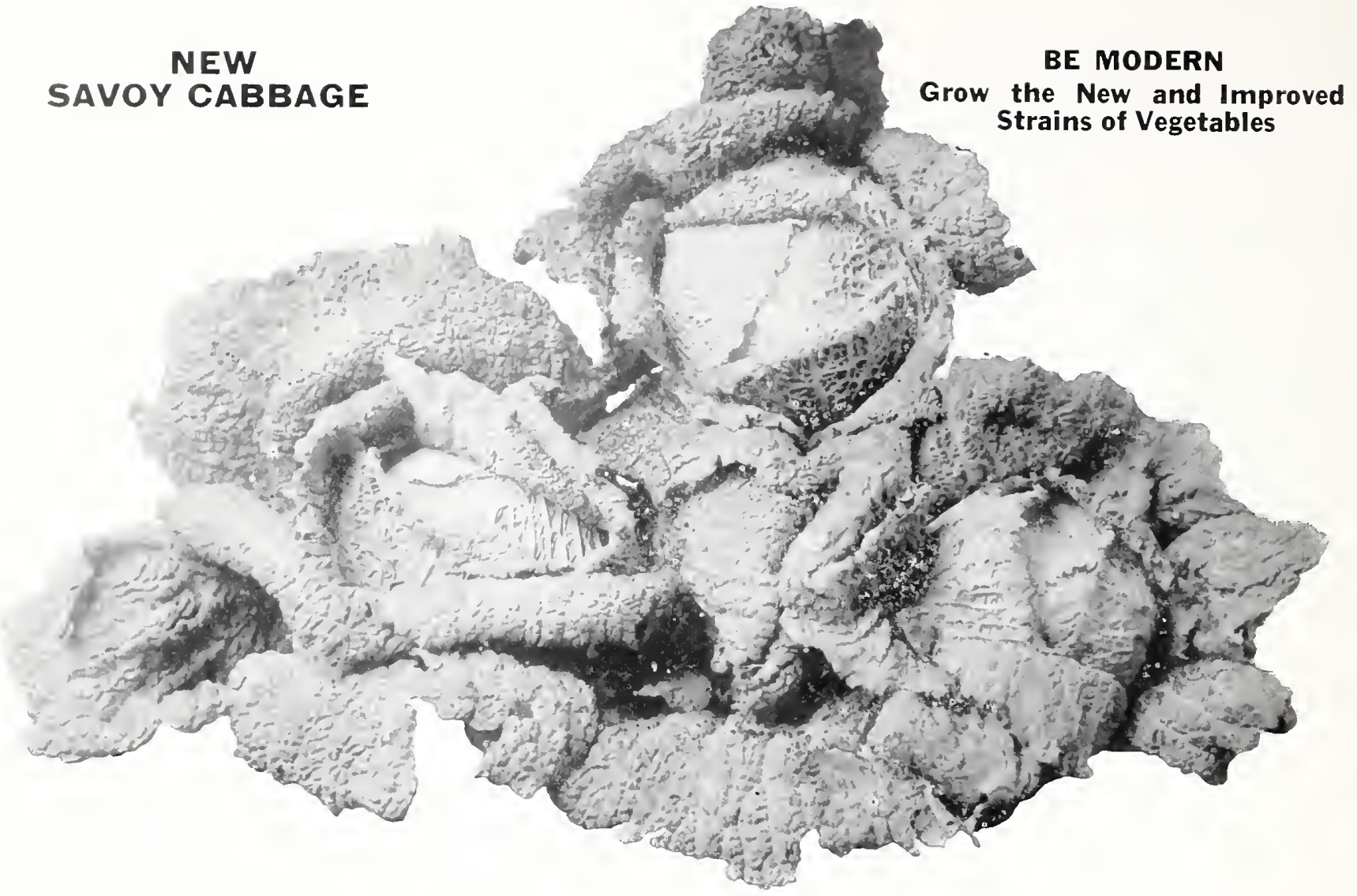

\section{CABBAGE SAVOY}

Trivett's Inverness. A high class Savoy which we offer for the first time. Splendid main crop; large, deep green; very solid heads of unsurpassed flavor.
Oz. $\$ 1.25$
$1 / 2$ oz. $70 \mathrm{c}$.
$1 / \mathrm{oz}$. $40 \mathrm{c}$.
Pkt. 25c.

\section{CELERY TREATED $\oplus$ SEEDS}

Trivett's Dwarf Giant. A distinct variety, dwarf and compact in growth, 15 to 18 inches high, easy to handle and blanch.

This is a Winter storing Celery of unsurpassed quality, pure white with cream colored heart.

The extremely broad, thick stalks are entirely stringless, crisp and juicy, of superior sweet, nutty flavor. Too brittle for distant shipping.

Oz. $\$ 5.00 \quad 1 / 20 z . \$ 2.75 \quad 1 / 4$ oz. $\$ 1.50 \quad$ Pkt. 50c.

Trivett's Giant Red. A large Winter keeping Celery of great merit, very vigorous grower and great solidity of stems; although immense in size and growth this Celery has the most delicious table quality, crisp, sweet, nutty flaror.

() 7 .

$1 / 2$ Oz.

$1 / \mathrm{OOZ}$

pkt.

$\$ 3.00$
51.75
$.95 \mathrm{c}$
$.25 \mathrm{c}$.

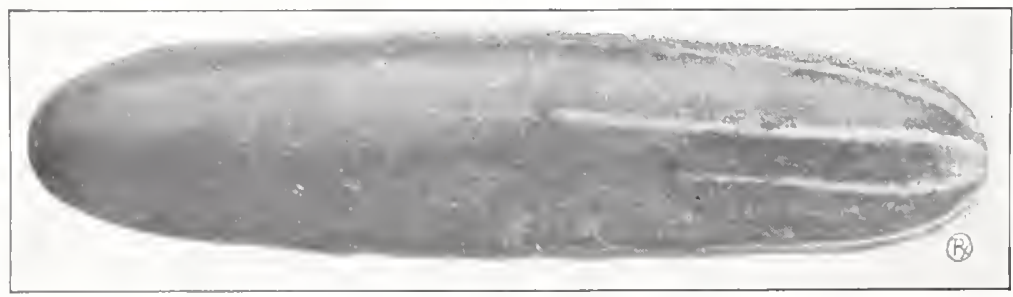

CUCUMBER Longfellow
NEW CARROT

Trivett's Scarlet Wonder. Cylindrical-shaped, ending with abrupt blunt point, almost entirely free from core; the flesh is vivid scarlet red, tender and delicate in flavor. The roots mature early, usually attaining a length of 4 or 5 inches. When bunched they present a very attractive appearance.

$1 / 4$ ib. $\$ 3.50 \quad$ Oz. 95 c. $1 / 2$ oz. 50c. Pkt. 35c.

“A Wonderful Sweet Corn!" This is the general comment of our customers regarding our

\section{SWEET CORN}

Trivett's Tangerine. Many have reported gathering the ears two weeks in advance of Golden Bantam, and the quality-Supreme! See our General Seed Catalogue.

\section{CUCUMBER}

Longfellow. This remarkable variety produces handsome fruits, 12 to 14 inches long by $21 / 2$ inches in diameter; flesh white and firm.

Fruits of Longfellow have been grown in the open so perfect as to be indistinguishable from the hothouse produce.

$1 / 4 \mathrm{lb} \ldots . . \ldots \$ 1.50$

Oz..........50c.

Pkt........ 20c. 


\section{EGGPLANT TREATED}

Trivett's Round White. The special merit of this white sort is the very refined, delicate flavor, much preferred by many to the black or purple varieties. 'The fruit does not grow as large. $1 / 4 \mathrm{lb} . \$ 3.00 \quad$ Oz. $\$ 1.00 \quad 1 / 2$ oz. $55 \mathrm{c} . \quad$ Pkt. $25 \mathrm{c}$.

\section{LETTUCE}

Sutton's Nonsuch Cos. One of the best; the head is compact, crisp and very sweet in flavor; stands for a considerable time before running to seed. (Sutton's $S_{e e d .)}$

Sutton's Tom Thumb. (Sutton's Seed.) An excellent dwarf Cabbage-headed Lettuce, similar in habit to Sutton's Commodore Nutt, but of paler green. The plants can be grown close together and are suitable for outdoors, franes or greenhouse. The small, tightly packed hearts supply an agreeable surprise by their superior quality; that delightful flavor which American visitors have found in Lettuce served to them in Fingland and the Continent. (Sutton's Seed.)

Pkt. 60c.

\section{MARTYNIA}

The young and tender seed pods provide a delicate, fancy pickle when gathered less than half grown.......... Oz. $75 \mathrm{c} .1 / 2$ oz. 40c. 1/4 oz. 25c. Pkt. $15 \mathrm{c}$.

\section{MELON TREATED SEEDS}

Oka. New Cantaloupe. This is a variety secured from Canada; it is of the Hackensack shape, a cross between Montreal Market and Banana; pink flesh and small seed cavity. It was originated by the Rev. Father Athanase of the Trappist Monastery at La Trappe, Quebec. It is recommended as a quick maturing, short season Melon of excellent quality.

Oz. 75c. $1 / 2$ oz. 40c. Pkt. 25c.

\section{ENGLISH GREENHOUSE MELONS}

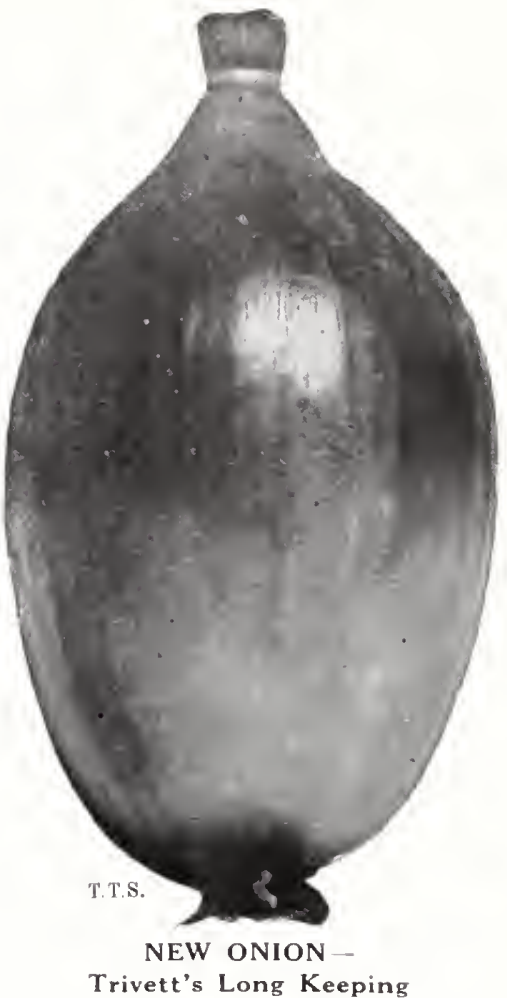

Sutton's Scarlet Hero. A new variety procured by crossing Sutton's Hero of Lockinge with Sutton's Scarlet. A splendid scarlet fleshed form of the popular "Hero." We can recommend this new variety to growers of choice greenhouse Melons with every confidence. (Sutton's Seed.) Pkt. \$1.25

Sutton's Emerald Gem. A magnificent Melon, fruit very handsome, flesh unusually thick and of a rich green color; superb in flavor. (Sutton's Seed.)

Pkt. $\$ 1.00$

\section{ONION TREATED SEEDS}

Trivett's Long Keeping. A new sort of excellent merit, long shaped, rich nut brown skin; first-class Winter keeper. The flesh is exceptionally mild and sweet. (Illustrated.)

$$
1 / 41 \text { b. } \$ 2.50 \quad \text { Oz. } 75 \mathrm{c} \text {. Pkt. } 25 \mathrm{c} \text {. }
$$

Trivett's Yellow King. A new sort; the largest and finest on the market; of globular shape, with yellow skin. The quality of the flesh is unsurpassed. Can be grown to an immense size for exhibition One of the best for garden culture. (Illustrated.)

$$
\text { Oz. } \$ 1.75 \quad 1 / 2 \text { oz. } \$ 1.00 \quad \text { Pkt. } 35 \mathrm{c} \text {. }
$$

\section{PARSNIP}

Invicta. A Carrot leaved Parsnip of very refined quality. Long, clean shaped roots with smooth white skin and firm, tender flesh, disease resistant and vigorous grower.

$$
1 / 1 \text { Ib. } \$ 2.50 \quad \text { Oz. 75c. Pkt. 25c。 }
$$

Sweet Apple. Introduced by us 1929, through the courtesy of a gardening friend. Round-shaped fruit, small in size, of the most agreeable, mild, sweet flavor.

Pkt. 50c.

Tomato-Pepper. (Or Squash Pepper.) Upright growth, small Tomato shaped fruit, mild flavor.

$$
\text { Oz. } 75 \text { c. } 1 / 2 \text { oz. } 40 \text { c. Pkt. } 15 \mathrm{c} \text {. }
$$

Tobasco. A hot Pepper, perhaps the hottest of all.

$$
\text { Oz. 90c. } \quad 1 / 2 \text { oz. 50c. Pkt. 20c. }
$$

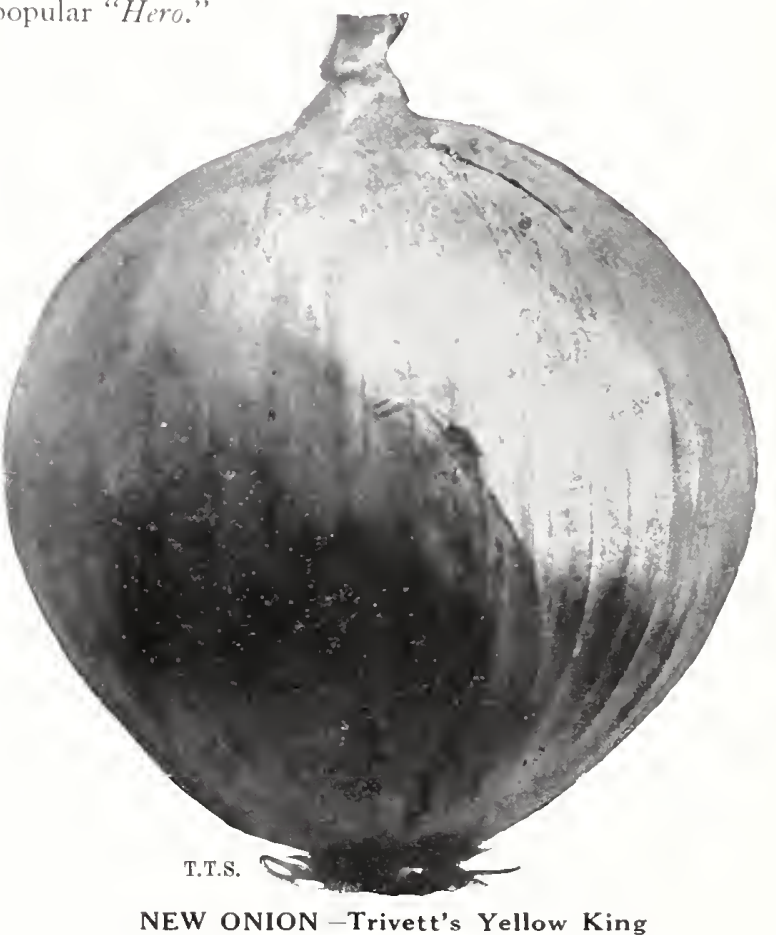

OLD VARIETIES OF VEGETABLES grown year after year "run out"-become exhausted

GROW THE NEW AND IMPROVED SORTS 


\section{NEW PEA FOR 1931 TRIVETT'S MONSTER}

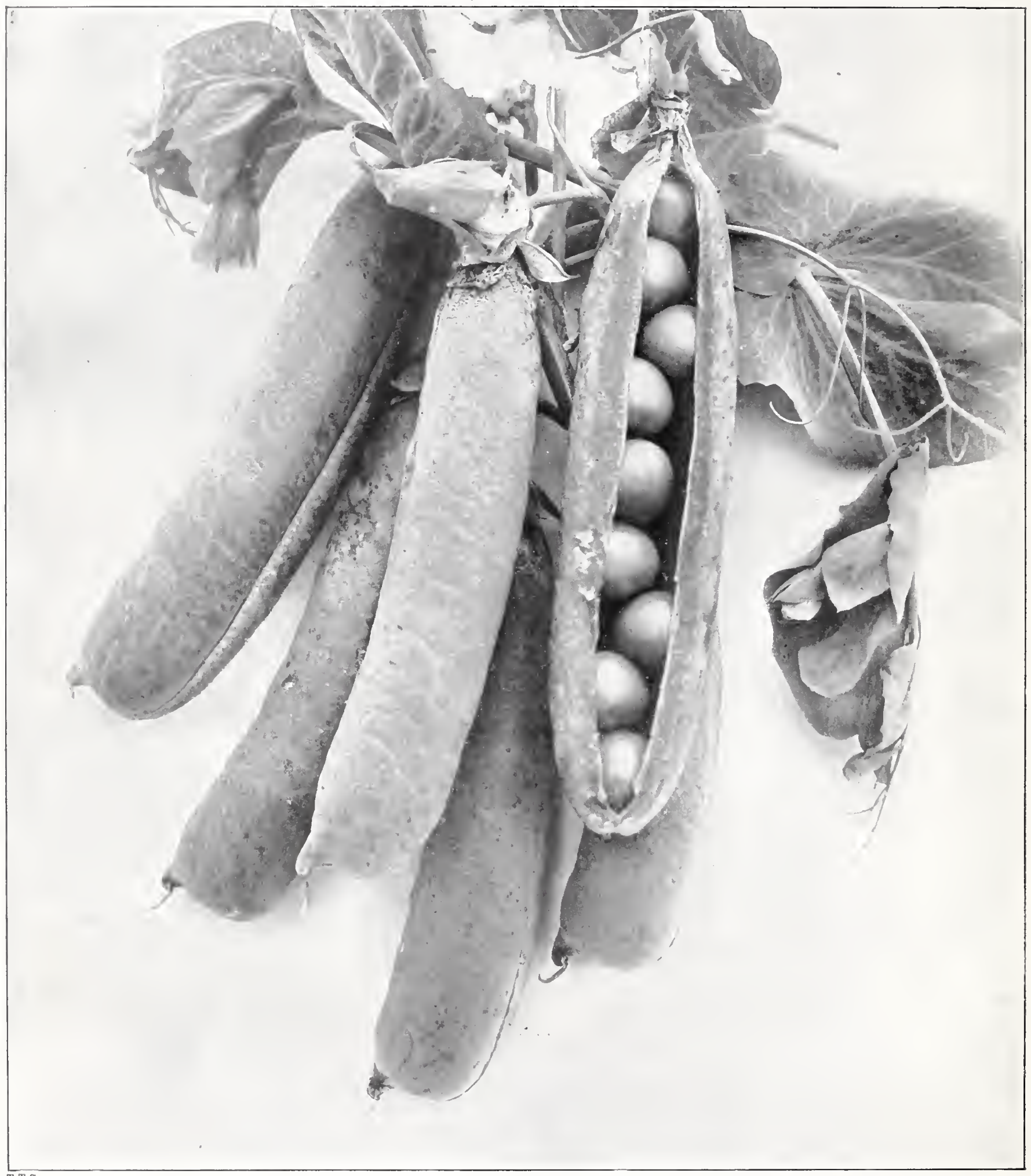

PEA-TRIVETT'S MONSTER (See opposile page) 


\section{Trivett's New Garden Peas for 1931 TREATED $O$ SEEDS}

OLD VARIETIES “RUN OUT”- KEEP UP-TO-DATE - GROW THE NEW SORTS

Standard varieties of vegetables reproducing themselves year after year through a long period of time, eventually "run out," exhaust themselves and become superseded by the newer and improved strains.

We are constantly on the watch for new and improved strains to offer our customers.

\section{NEW EARLY PEAS}

Aviator. Raised by Messrs. Laxton of England. Quite distinct and combines all the best qualities of two very popular sorts, viz., Laxton's Superb and British Lion. It is a blue, round-seeded sort, hardy and can be sown very early; it is a first early variety growing about $31 / 2$ feet high, produces handsome, long, well filled pods containing seven to ten peas of unsurpassed quality. Highly recommended (English grown seed).

4 qts. (8 lbs.) $\$ 7.00$ Pt. (1 1b.) $95 \mathrm{c}$.

Qt. (2 lbs.) $\$ 1.80$

Trivett's Abundance. We have pleasure in offering our customers this grand new early Pea. A round, blue seed sort maturing at about the same time as Gradus, but producing about $25 \%$ more crop. Hardy, strong growing vines about 3 feet in height, covered with good sized pods, containing 7 to 8 green peas of superb sweet flavor. Can be sown early.

4 qts. (s lbs.) $\$ 5.00$

Qt. (2 lbs.) $\$ 1.35$ Pt. (1 lib.) $75 \mathrm{c}$.

Greenmantle. New and distinct Pea of the Superb type, but having intensely dark green foliage. Pods mostly in pairs, $31 / 2$ to 4 inches long, dark green, 7 to 8 large green peas in pods; of good flavor; a heavy cropper. Height about 2 feet. 4 qts. (8 lbs.) \$7.00 Qt. (2 lbs.) $\$ 1.80$ Pt. (1 lb.) $95 \mathrm{c}$.

\section{SECOND EARLY PEA} Sutton's Phenomenon. This splendid Pea is regarded by many as being one of the finest dwarf Peas ever introduced. The crop produced is quite prodigious and the pods are of extraordinary size, no other dwarf sort can surpass it in size of pod; 9 to 12 peas in a pod. The table quality is very choice. Height about 2 feet.

4.qts. (s lbs.) $\$ 7.00 \quad$ Qt. (2 lbs) $\$ 1.80$

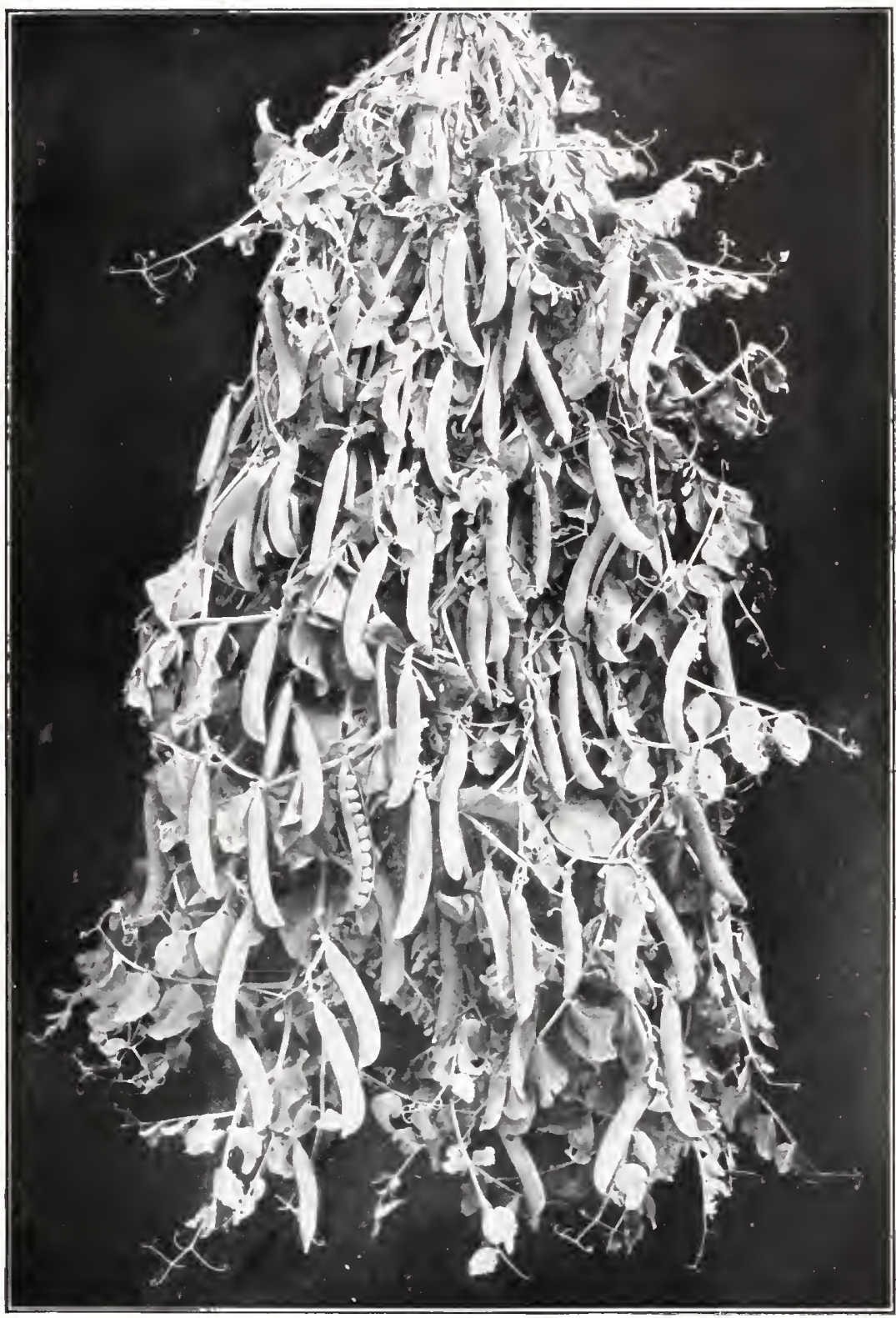
Pt. (1 lb.) $95 \mathrm{c}$.

\section{NEW MAIN CROP PEAS}

Trivett's Monster. A grand new sort; midseason, producing very large, rich, dark green pods which are filled with exceptionally large peas, blue green in color and of unsurpassed table quality. When cooked this sort will be found to contain the genuine rich sweet marrowfat flavor. The vines are of vigorous, healthy growth, reaching a height of about 5 feet. Being a wrinkled sort, it should not be sown too early. Stock very limited. ... ... ... 1/2 pt. pkts., each 95c.
Onward. One of the best of the recent introductions. Coming in just ahead of Telephone. It is immensely productive with its handsome dark green pods produced in great profusion on sturdy, healthy vines which grow about $2 \frac{1}{2}$ feet in height. The blunt-nosed pods hang in pairs and are very tightly packed with peas of delicious, sweet flavor. A distinct and excellent variety. Highly recommended.
4 qts. (8 lbs.) $\$ 4.25$
Qt. (2 lbs.) $\$ 1.10$
Pt. (1 lb.) 60c. 


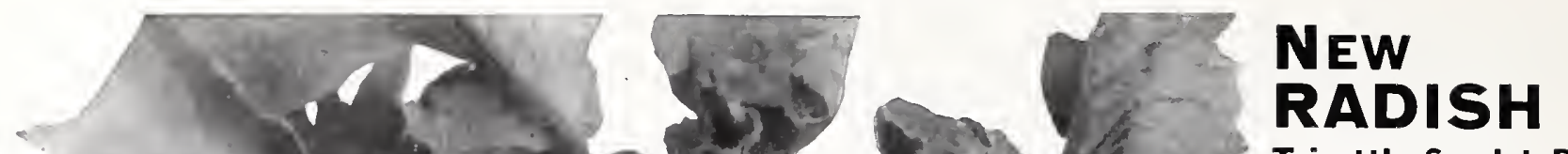

Trivett's Scarlet Ball.

(Illustrated.) The color is rich glowing scarlet. Perfect ball shaped with practically no tap root and very small foliage. The flavor is unusually crisp and sweet.

If required for forcing this sort will be found much superior to most of the older red varieties. The roots are remarkably quick in forming.

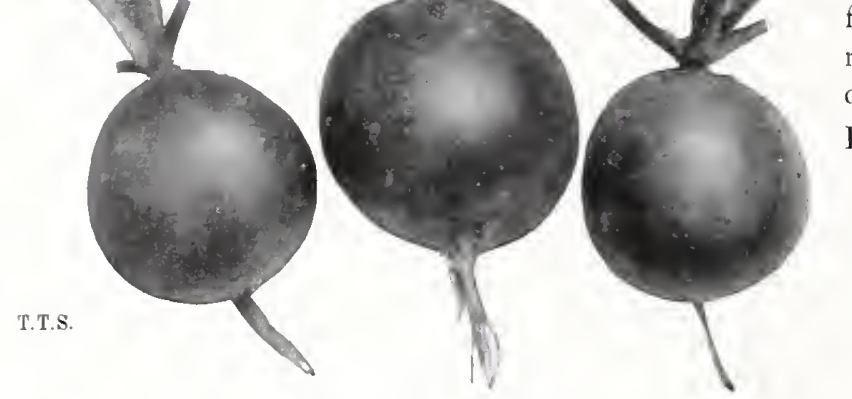

Lb. $\$ 4.00 \quad 1 / 4 \mathrm{lb} . \$ 1.25 \quad$ Oz. 50c. Pkt. 20c.

A full list of all the finest varieties of Radish will be found in our General Seed Catalogue. A copy will be gladly furnished on request.

NEW RADISH-Trivett's Scarlet Ball

$$
\text { (2) }
$$

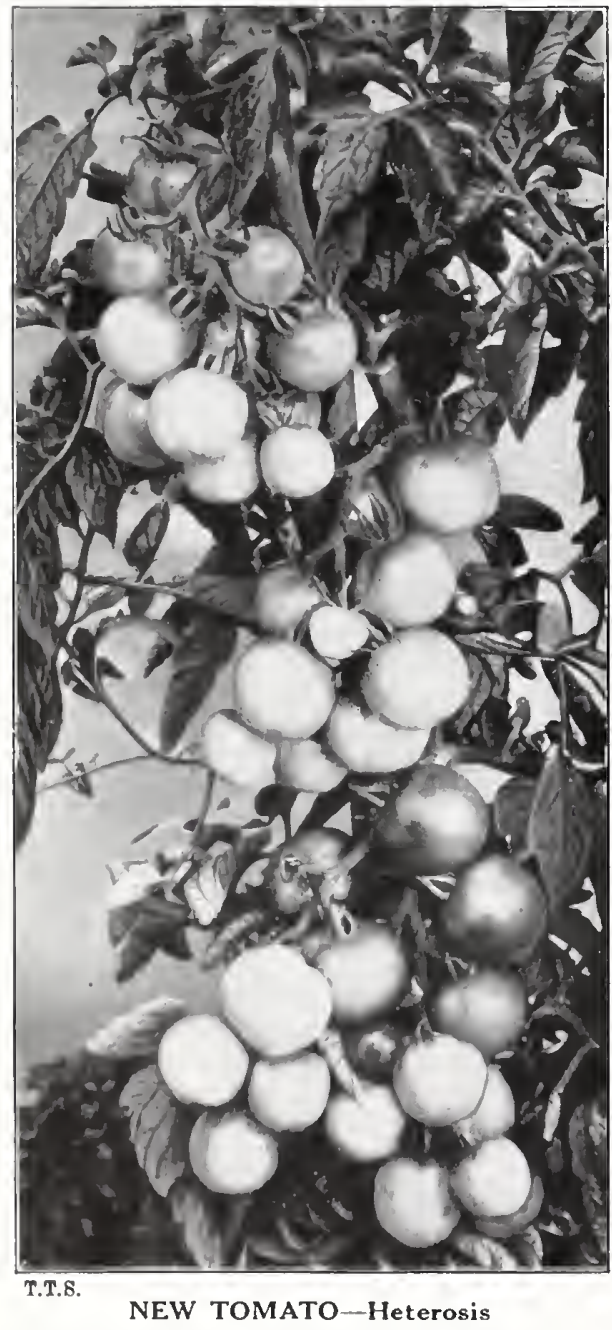

\section{NEW SQUASH}

Giant Straight Neck. A valuable selection from the Giant Summer Crookneck, having all the good qualities of its parent with none of its defects. The fruits measure about 18 inches in length, are of deep orange yellow color, warted and with much thicker flesh and more meaty neck than the old type. There are several strains of this being offered. The one we offer is the genuine type and is secured by us from the originator.
Lb. $\$ 5.00$
$1 / 4 \mathrm{lb} . \$ 1.50$
Oz. 50c.

\section{NEW TOMATOES TREATED $\Theta$ SEEDS}

Marglobe. New disease resistant, distinct variety which has proved its value under different conditions of soil and weather. Produces a maximum crop of large, well rounded, bright scarlet fruit; very solid flesh and excellent eating qualities. It is second early in maturing and the plants are medium large and erect. The foliage shades the fruit, thus preventing sun scald. The best of the new disease resistant varieties. SPecial Stock.

$$
\text { Oz. } \$ 1.00 \quad 1 / 2 \text { oz. } 60 \text { c. } 1 / 4 \text { oz. } 35 \text { c. Pkt. } 20 \text { c. }
$$

Heterosis. The most prolific sort in existence. Will yield about $25 \%$ more than any other variety. The vigorous plants produce double clusters of 20 to 25 fruits together. The flavor is exceptionally fine and agreeable. The plants are best cultivated on one single stalk and in this way an immense production will be obtained (as seen by the photograph.) W W must especially call attention to the fact that this variety was created by the "Heterosis" method of hybridization; in other words, first generation seed. The seed we offer is crossed each year. If this is not done, a worthless mixture would be the result.

$\begin{array}{llllllll}\text { (Originator's seed.) } \ldots & \ldots & \ldots & \ldots & 5 \text { pkts. } \$ 2.25 & \text { Pkt. 50c. }\end{array}$

Carter's Fruit. (Raiser's description.) We have at last produced a Tomato perfect in outline (from a cross between Sunrise and Ponderosa). It is a heavy cropper, but more important, it is most fleshy and contains very little seed, practically the whole of the space being taken up by the well flavored flesh. The average fruit is about the size and shape of a tennis ball. Another advantage, which is of great value for culinary purposes, is that the skin is very easily removed. As a cooking variety it is unique, the shape and solidity of the flesh making it particularly suitable for all dishes where the fruit has to be stuffed. Slice Carter's Fruit from the stalk downwards; peels like a Peach and can be eaten like an Apple. ... ... ... Pkt. $\$ 1.00$ 
Much can be said in praise of the wood our tubs are made from, namely, "Heart Cypress," but briefly, it has proved to be decidedly superior to all other woods, not only in durability but in appearance. It does not need a coating as a filler, as the wood naturally contains a certain amount of oil. Consequently it does not warp, shrink or swell, and in general it is the wood for plant tubs.

The workmanship on these tubs is equally good. No tub goes from the shops that has not been thoroughly made, and made to last for years, and our tubs are serviceable for practically every situation.

If you need tubs, buy good ones, and they will last you for many years. Most tubs, of course, look alike when they are freshly painted, but it is only after using them that their value can be realized.

A Special Line, for People Who Demand the Best

For the Regular Standard Grade Tubs Please Refer to Our General Catalogue

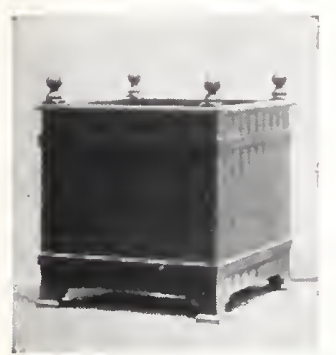

Square Tub, No. 1

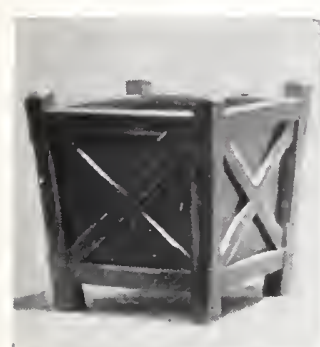

Square Tub, No. 2

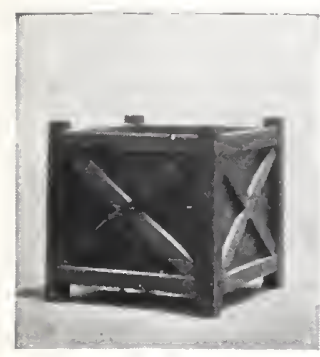

Square Tub, No. 11

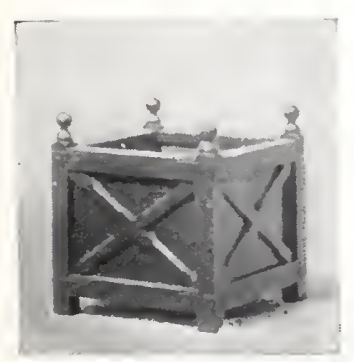

Square Tub, No. 12

\section{Square Tub, No. 1}

Straight sides, iron bands, iron feet, ball tops, painted green, iron bands painted black.

Inside diameter.

15 or 16 inches

17 or 18 inches

19 or 20 inches

21 or 22 inches

Larger rizes can be supplied to order.

\section{Square Tub, No. 2}

slanting sides, mission style, painted green.

Inidide diameter

10) or 12 inches

1,3 or 14 nches

15 or 16 inches

17 or 18 inches

19 or 20 inches.

21 or 22 inches

Larger sizes can be supplied to order.

\section{Square Tub, No. 11}

Straight sides, mission style, painted green.

Inside diameter.

10) or 12 inches

13 or 14 inches

15 or 16 inches

17 or 18 inches

19 or 20 inches

21 or 22 inches.

Larger sizes can be supplied to order.

\section{Square Tub, No. 12}

Straight sides, corner posts with ball tops, painted green. Only made in sizes 15 to 28 inches.

Inside diameter Each

15 or 16 inches.......... \$9.25

17 or 18 inches........... 10.00

19 or 20 inches........... 11.75

21 or 22 inches............ 12.75

28 inches is the largest size we can supply in this style.

\section{Square Tub, No. 13}

Straight sides, lattice work, sand-

stone finish.

Inside diameter

10 or 12 inches

13 or 14 inches

15 or 16 inches

17 or 18 inches

19 or 20 inches

21 or 22 inches

Each
+5.00
6.25
8.50
9.25
11.00
12.00

Larger sizes can be supplied to order.

\section{Octagonal Style}

Only made in sizes 15 to 24 inches.

Inside diameter

15 inches.

16 inches

17 inches.

18 inches

19 inches

20 inches

21 inches.

22 inches

Eiach

$\$ 10.00$

10.75

1.3 .00

13.75

14.50

$1+.75$

16.00

$2 t$ inches is the largest size we can supply in thas style.

\section{Square, Round Corners}

Only made in sizes 19 to $2 t$ inches. Inside diameter

19 inches

20 inches

21 inches

22 inches

$2 t$ inches is the largest size we can supply in this style.

\section{Round B. H. Tub}

Painted green, black hoops.

Inside diameter
10 or 11 inches. No handles. $\$ 1.75$

12 or 13 inches. No handles. 2.75

14 inches. Drop handles.

15 inches. Drop handles.

16 or 17 inches. Drop handles.

18 or 19 inches. Drop handles.

20 or 21 inches. Drop handles.

22 inches. Drop handles.

Larger sizes can be supplied.

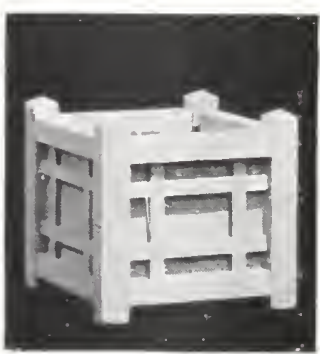

Square Tub, No. 13
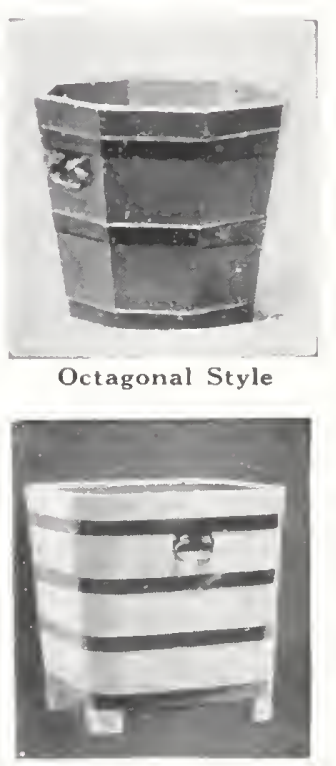

Square, Round Corners

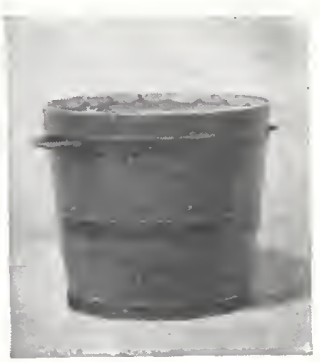

Round B. H. Tub

\section{TRIVETT'S TESTED SEEDS}




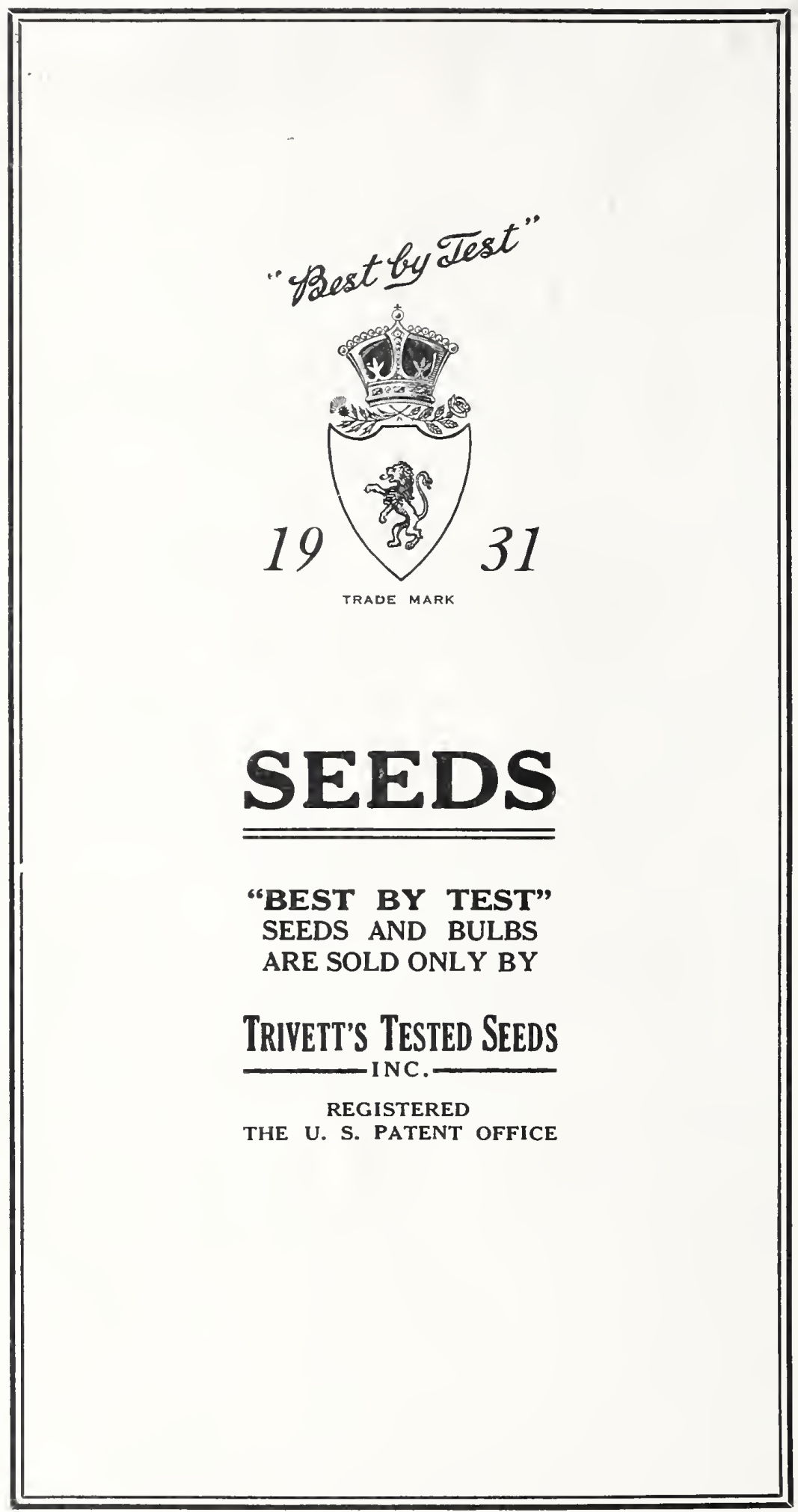

